1. copers

\title{
MASTER $\mathrm{VIN}-115$
}

\section{U.S, ATOMIC ENERGY COMMISSION}

RAW MATERIALS DEVELOPMENT LABORATORY WINCHESTER, MASSACHUSETTS

\section{OPERATED BY \\ NATIONAL LEAD COMPANY, INC. Contract AT (49.6) 924}

\section{SUPMAMYRY REPORT 1954 - 1959}

\section{AEC RESEARCH AND DEVELOPHENT REPORT}

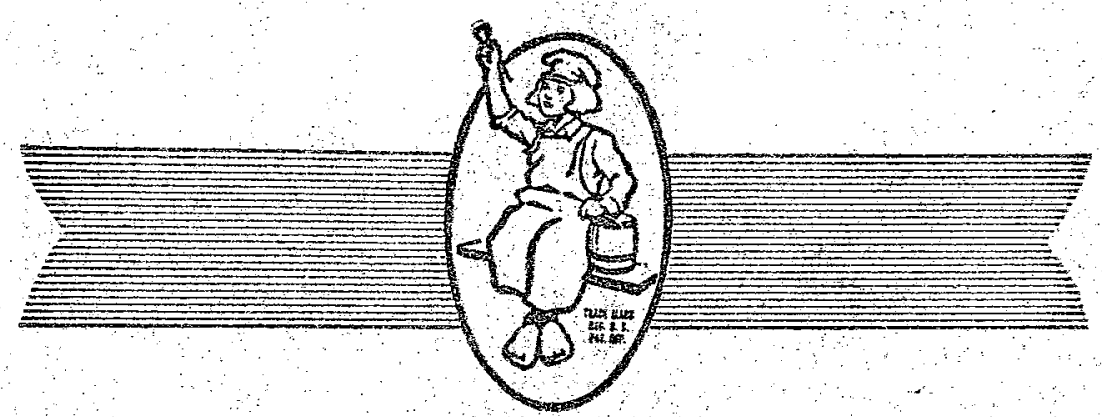




\section{DISCLAIMER}

This report was prepared as an account of work sponsored by an agency of the United States Government. Neither the United States Government nor any agency Thereof, nor any of their employees, makes any warranty, express or implied, or assumes any legal liability or responsibility for the accuracy, completeness, or usefulness of any information, apparatus, product, or process disclosed, or represents that its use would not infringe privately owned rights. Reference herein to any specific commercial product, process, or service by trade name, trademark, manufacturer, or otherwise does not necessarily constitute or imply its endorsement, recommendation, or favoring by the United States Government or any agency thereof. The views and opinions of authors expressed herein do not necessarily state or reflect those of the United States Government or any agency thereof. 


\section{DISCLAIMER}

Portions of this document may be illegible in electronic image products. Images are produced from the best available original document. 
LEGAL NOTICE

This report was prepared as an account of Government sponsored work. Neither the United States, nor the Commission, nor any person acting on behalf of the Commission:

A. Makes any warranty or representation, express or implied, with respect to the accuracy, completeness, or usefulness of the information contained in this report, or that the use of any information, apparatus, method, or process disclosed in this report may not infringe privately owned rights; or

B. Assumes any liabilities with respect to the use of, or for damages resulting from the use of any information, apparatus, method, or process disclosed in this report.

As used in the above, "person acting on behalf of the Commission" includes any employee or contractor of the Commission to the extent that such employee or contractor prepares, handles or distributes, or provides access to, any information pursuant to his employment or contract with the Commission. 
WIN-115

Metallurgy-Raw Materials

M-3679 - (23rd Edition)

- 1 -

TOP ICAL REPORT WIN-115

SUMMARI REPORT, 1954-1959

RAW MATERIALS DEVELOPMENT LABORATORY

WINCHESTER, MASSACHUSETTS

AND

GRAND JUNCTION, COLORADO

September 30, 1959

Approved By:

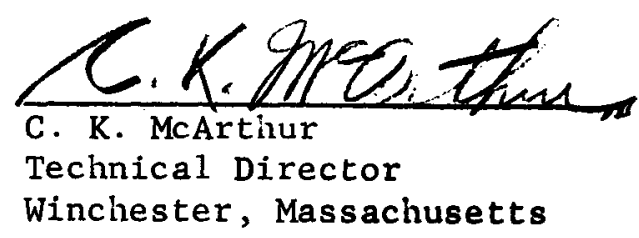

U. S. Atomic Energy Commission

Contract No. AT(49-6)-924

NATIONAL LEAD COMPANY, INC.

Raw Materials Development Laboratory

Winchester, Massachusetts 
WIN-115

Metallurgy-Raw Materials

M-3679 - (23rd Ed.)

REPORT BISTRIBUTION

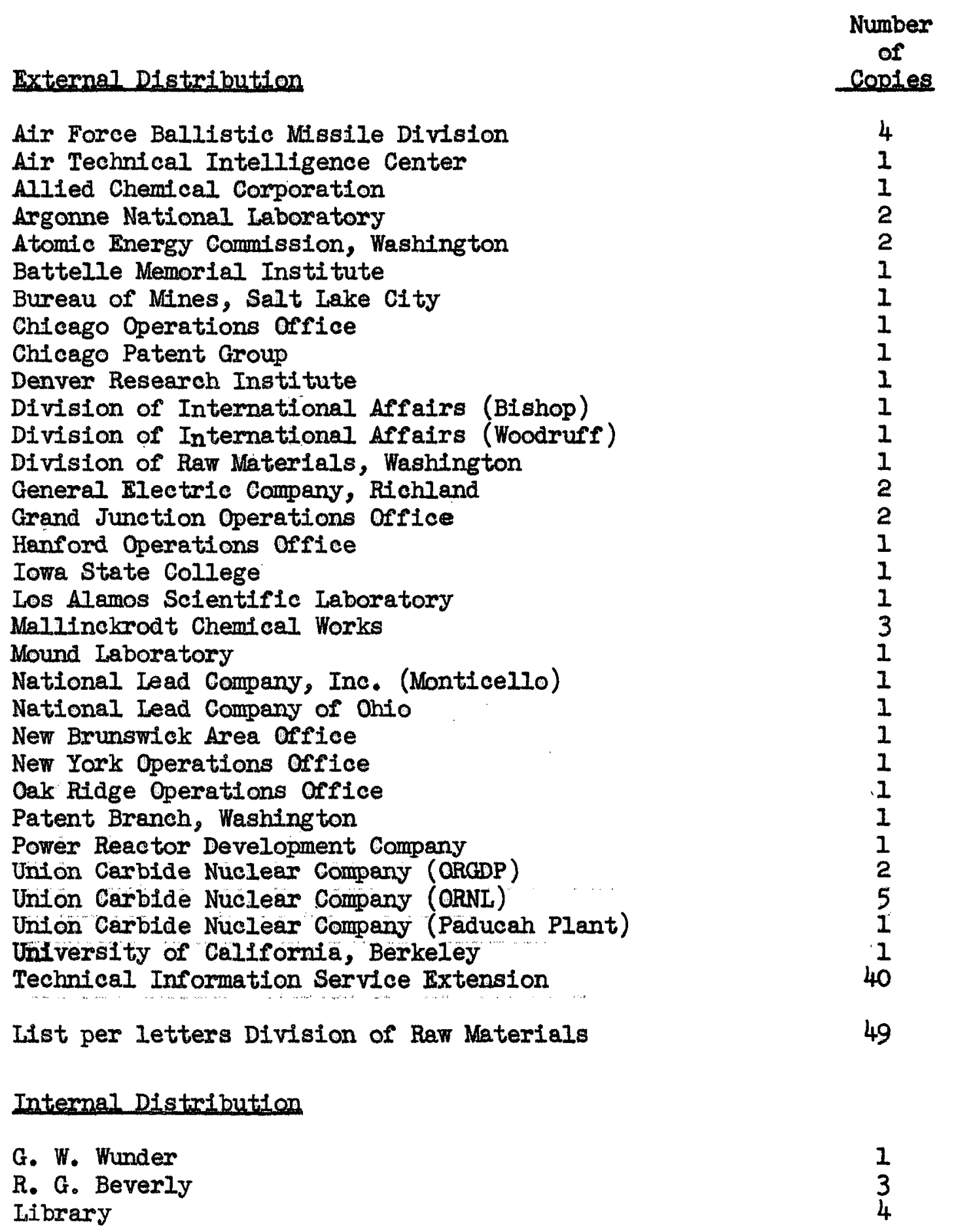


WIN-115

Metallurgy-Raw Materials M-3679 - (23rd Ed.)

Additional Distribtuion as per letter Division of Raw Materials

External Distribution

Number of

Union Carbide Nuclear Company (Lake) - G. J. Colo.

Union Carbide Nuclear Company (Sada) - Uravan, Colo.

Union Carbide Nuclear Company (Temple) - Rifle, Colo.

Trace Elements Corporation (Pembiridge)

Vanadium Corp。of America (Brinker)

Climax Uranium Company (Mastrovich)

Climax Molybdenum Company (Cuthbertson)

Kerr-McGee Oil Industries, Inc. (Mattson) - Golden, Colo.

Kerr-McGee Oil Industries, Inc. (Bolton) - Shiprock, N. Mexico

The Anaconda Company (Fitch) - Grants, New Mexico

The Anaconda Company (Holderreed) - Anaconda, Montana

Vitro Uranium Company (Hall)

Mines Development, Inc。(Gray) - Denver, Colo.

Mines Development, Inc. - Dist. Office (Webb) - Edgemont, S.D.

Rare Metals Corp. of America (Kline) - Salt Lake City, Utah

Rare Metals Corp。of America (Runke) - Tuba City, Arizona

Uranium Reduction Company (Hollis)

Texas-Zinc Minerals Corp. (Hayes) - Grand Junction; Colo.

Texas-Zinc Minerals Corp。(Apland) - Mexican Hat, Utah

Western Nuclear Corp. (Joyce)

Dawn Mining Company (Crowhurst)

Lucky Mc Uranium Corp. (Mecia) - Palo Alto, California

Lucky Mc Uranium Corp. (Quine) - Riverton, Wyoming 1

Gunnison Mining Company (Shreve)

Homestake-New Mexico Partners (Osborn)

Homestake-Sapin Partners (Jones)

Homestake Mining Company (Herz)

Kermac Nuclear Fuels Corp. (Cobb)

Phillips Petroleum Company (Hipp) -| Bartlesville, Okla.

Phillips Petroleum Company (Ruoho) - Grants, New Mexico

Columbia-Southern Chemical Corp. (Sindlinger)

Fremont Minerals Corp. (Bryant)

Apex Uranium, Inc. (Silver)

Federal Uranium Corp: (Neyman)

Lakeview Mining Company (Thornburg)

Arthur D. Little, Inc.

Cotter Corporation

Colorado School of Mines Research Foundation; Inc. (Crabtree)

$H$ 。 L Hazen, Inc 。 (Hazen)

Nuclear Metals Corp. (Bitzer)

Robert R. Porter, Consulting Metallurgist, Salt Lake City, Utah

John L. Chapman, Grand Junction, Colo.

Alvin H. Ross, Consulting Metallurgist, Toronto, Ontario, Canada

Industrial Hygiene Branch (N. Y. Operations Office) (Harris)

The Anaconda Co. (Hayner)

Uranium Reduction Company (Snyder) 


\section{TABLE OF CONTENTS}

$\begin{array}{lr} & \text { Page } \\ \text { INTRODUCTION } & 3 \\ \text { ACKNOWLEDEMENTS } & 4 \\ \text { HISTORY OF THE PROJECT } & 5 \\ \text { RESUME OF RESEARCH WORK } & 7 \\ \text { Fundamental Research } & 7 \\ \text { APplied Research } & 7 \\ \text { Analytical Testing } & 10 \\ \text { Amenability Testot Plant } & 10 \\ \text { Mil1 Assistance } & 11 \\ \text { DESCRIPTION OF FACILITIES } & 14 \\ \text { Winchester Laboratory } & 15 \\ \text { Grand Junction Pilot Plant } & 15 \\ \text { PERSONNEL } & 15 \\ \text { PUBLICATIONS } & 25 \\ \text { PATENTS } & 28 \\ \text { APPENDIX Rubject } & 30 \\ \text { Topical Reports classified by } & \\ \text { Urantents of Monthly Progress Reports } & 32 \\ \text { WIN Reports and abstracts } & 34 \\ \text { MCCO Reports and abstracts } & 35 \\ \text { Reports and abstracts } & 75\end{array}$




\section{INTRODUCTION}

The recovery of uranium from its ores has been the subject of extensive research in several laboratories, under the sponsorship of the Raw Materials Division of the Atomic Inergy Commission, for the last 15 years. A major role in this work has been played by the Raw Materials Development Laboratory, Winchester, Massachusetts, and the Raw Materials Development Pilot Plant, Grand Junction, Colorado. Since July 1954, these projects were operated for the Government by the National Lead Company. / The purpose of this report is to review briefly the activities of the National Lead Company during the performance of this work and to present a guide to the uranium industry to aid in the location of research information pertinent to the winning of uranium from its ores.

Because much of the early work on this project, accomplished under the direction of $\mathrm{M}_{0} I_{0} \mathrm{~T}_{\text {。 }}$ and American Cyanamid Company, was reported at a time when raw materials technology was classified, a complete list of publications made by these two groups from 1944 to 1954 is presented in the appendix. 
WIN -115

-4 -

\section{ACKNOWLEDGEMENTS}

The National Lead Company would like to express its appreciation for the assistance and cooperation extended by Mr. E. C. Van Blarcom, Dr. G. G. Marvin, and Mr. J. C. Johnson, U.S. A.E.C., Washington, D. C. Their assistance was at all times helpful in the development of a full and successful raw materials development program. Thanks is also due Mr. A. E. Jones, U.S. A.E.C., Grand Junction, Colorado, and Mr. S. P. Wimpfen formally of that organization for their advice and encouragement on this program.

Mr. G. W. Wunder, Vice President and General Manager of the National Lead Company, Inc., contract operators for the Winchester Laboratory and the Grand Junction Pilot Plant, and Dr. Alex Stewart, retired, Vice President and General Manager, National Lead Company, Inc., contributed in considerable measure to the success of this project.

No attempt will be made here to credit the other research facilities engaged in uranium raw materials research for their individual contribution to the industry and to the program at the Raw Materials Development Laboratory. The excellent liaison and unselfish cooperation of the other research facilities in this work was of great value to the program. 


\section{HISTORY OF THE PROJECT}

The Raw Materials Development Laboratory had its beginning at the Massachusetts Institute of Technology under the direction of Professor A. M. Gaudin in July of 1944. At this time Lt. Co1.

J. E. Vance and Major P. H. Merritt of the Manhattan Engineering District conferred with M.I.T. personnel on the treatment of Congo rejects for the extraction of uranium. The initial purpose of the project was to study the treatment of low-grade uranium ores with emphasis on the principles involved rather than for the specific solution of any one problem. The initial plan was modest.

As the work developed, it became clear that ore of much lower grade would have to be treated to provide increased uranium production. The project, therefore, was increasingly orientated to the effective processing of relatively low-grade materials. As the problems increased in variety and complexity, as well as in significance, the site of the research facilities was moved to larger quarters at the Watertown Arsenal, Watertown, Massachusetts. The project remained under the direction of the M.I.T., Mineral Engineering Laboratory, at Watertown until March 1951. During the seven years that this group worked on the problems of winning uranium from its ores, tremendous progress was achieved in the hydrometallurgy of uranium. Much credit is due Professor Gaudin and his organization for the successful start of the Raw Materials Development Laboratory. In March 1951 the management of the project was assumed by American Cyanamid Company under the direction of Mr. D. M. Kentro. American Cyanamid operated the project until July 1954. During this period the technology of processing uranium ores was greatly advanced not only by the group under American Cyanamid but other research institutions in the field such as Battelle Memorial Institute, Arthur D. Little, Inc., Columbia University, The Merrill Company, Dow Chemical Company, and others.

During this period the new quarters of the laboratory at Winchester, Massachusetts, were constructed. This laboratory is described in detail under the section of this report entitled, "Description of Facilities." During this period the first small pilot plant was constructed at Grand Junction for the express purpose of developing the resin-in-pulp process.

In July of 1954, the project was taken over by the National Lead Company, Inc。Dr.Alex Stewart, Director of Research for the National Lead Company, was Vice President and General Manager of National Lead Company, Inc., and Mr.J.S.Breitenstein was Technical Director of the project. Under National Lead Company, the large pilot plant was completed in Grand Junction and the project reached its peak of activity. 
WIN-115

During the period that the project has been in operation, the domestic uranium raw materials industry grew from a small-scale operation, dependent on a few small vanadium-uranium mills, to a large efficient industry, mining and processing many milifions of tons of ore each year. The contribution of the research groups that developed the metallurgical processes that are in use in the uranium mills to the growth of the industry was enormous. Not only was the cost of processing the ore continuously reduced but low-grade and refractory deposits of ore were rendered amenable through technological advances. 


\section{RESUME OF RESEARCH WORK}

\section{Fundamental Research}

In chemical processing, a fundamental knowledge of the chemical reactions involved is important since such an understanding usually discloses means of improving existing processes. Several investigations which may be classed as fundamental research, were conducted at the laboratory.

As the need arose fundamental research was conducted in connection with leaching, oxidation-reduction, ion exchange, solvent extraction, and precipitation. One such specialized piece of research work on which relatively more time was spent included a study of the kinetics and mechanism of the reactions involved in the dissolution of uranium in carbonate-bicarbonate solutions which established the order of magnitude of the variables. An interesting sidelight of this study was the development of a technique for using powdered specimens in the kinetic studies of liquid-solid systems.

Because of the importance of vanadium in alkaline leach - chemical precipitation circuits, the study of the nature of vanadium species in carbonate solutions and the interaction of vanadium and uranium in alkaline systems was carried out Definite evidence of uraniumvanadium interaction was observed, thereby explaining the difficulty in selectively precipitating uranium from carbonate solutions of appreciable vanadium content.

In connection with the recovery of uranium from acid leach liquors a study was made to determine the structure of the uranyl sulfate complex ion species formed in the extraction of uranium with amine solvents.

\section{Applied Research}

In the ion exchange field, the laboratory actively engaged in a program of resin testing which included cooperation with resin manufacturers in checking new resin products to determine the adaptability of new resins or resin forms to uranium recovery processes. Another ion exchange project was devoted to the investigation of molybdenum poisoning. As a result of this investigation, an eluant was found which removes the molybdenum from the resin readily and inexpensively. Methods of molybdenum removal from leach liquor by charcoal adsorbtion and partial neutralization were also tested extensively.

Results of fundamental ion exchange studies indicated that an alkaline resin-in-pulp process was feasible. Simultaneous pilot 
plant and laboratory programs developed this scheme into a practical and economic process. Studies on $\mathrm{pH}$ control showed effective methods of preferentially loading uranium and eliminating vanadium.

A continuous, countercurrent, resin-in-pulp flowsheet was developed and tested in the laboratory. Uranium was adsorbed in three or four stages compared to eight to ten stages required in conventional basket-type RIP systems and was subsequently removed from the resin by continuous countercurrent elution either in a column or tanks.

Uranium reduction processes employing sodium amalgam and hydrogen were studied in the laboratory as alternate methods for uranium precipitation from carbonate leach liquors to supplant the caustic precipitation method. The sodium amalgam process did not look attractive but the hydrogen reduction method offered more promise and was tested in the Pilot Plant. When laboratory and pilot plant tests indicated organic material in some ores interfered with leaching and uranium precipitation in alkaline circuits, a program was initiated to develop methods of minimizing this interference. Adsorption on charcoal and electrolytic oxidation of the organic material were two of the methods most actively pursued toward elimination of this problem.

of particular importance to the uranium industry was the research conducted on improving uranium extractions during carbonate leaching. Following a study of chemical oxidants, it was found that the oxidation of uranium by air in the presence of copper-ammonia complex ions as a catalyst resulted in efficient dissolution of uranium at a cost considerably less than was possible with potassium permanganate.

Solvent extraction studies led to the development of the Eluex process by which sulfuric acid eluates from an RIP system are solvent extracted, the uranium is stripped from the solvent, and then precipitated from the high-grade, high-purity strip solution. Advantages of the process are lower reagent consumption, elimination of nitrate from the system, and a low-impurity, high-grade product.

Considerable laboratory work was done on a process consisting of direct solvent leaching of uranium from acid-pugged ores. Although a simple mechanical method for performing the operation was not found, attractive features were the recovery of uranium from essentially dry ore so that the solid-liquid separation step required after conventional leaching procedures might be eliminated. Results demonstrated the workability of the process but cost evaluations indicated that, at the time, the process was not competitive with more conventional milling processes.

Working closely with the manufactures, the laboratory evaluated a large number of new amine solvents, and this close cooperation accelerated the development of new uranium extractants which greatly increased the flexibility of the solvent extraction process while reducing chemical costs. 
One of the major efforts of the laboratory and pilot plant was the development of a process for recovery of uranium from uraniferous lignites. After extensive laboratory tests on roasting, leaching, and solvent extraction, a flowsheet was developed which was evaluated in the pilot plant. This work solved a particularly difficult extraction problem since these ores proved to be nonamenable to alkaline leaching and the acid leach and ion exchange approach was complicated by the presence of high concentrations of molybdenum, iron, sulfate, and organic matter in the leach solutions.

A new process for the production of green salt (UF 4 ) was developed which consists of preparation by solvent extraction of a highly purified and concentrated uranium solution and precipitation of dense $\mathrm{UF}_{4}$ by catalytic reduction with sulfur dioxide. The process is unique in that the feed material may be an acid leach solution or any other solution from which uranium can be solvent extracted. The $\mathrm{UF}_{4}$ product meets the exacting chemical and physical specifications required for the production of metal from the green salt. The chemical costs of the process are only slightly greater than the cost of producing yellow cake. The process steps are simple and the capital cost is not significantly greater than that of conventional solvent extraction circuits producing yellow cake.

The recovery of uranium from magnesium fluoride slag and bomb liner material originating at the uranium metal refineries was also intensively studied. A simplified sulfuric acid leaching and solvent extraction process was developed which will recover the uranium as a very high-grade yellow cake or a $\mathrm{UF}_{4}$ product at low capital and operating costs.

The past year of research work at the laboratory has been devoted almost exclusively to finding and testing a method by which radioactive contaminants could be removed economically from uranium mill tailings. Radium and thorium are the primary radioactive contaminants in the mill waste streams and research was largely confined to measuring and studying means to reduce these materials. A process for treatment of acid mill tailings was resolved that involved neutralization of the tailings solution followed by barite treatment either in agitated tanks or in a percolation bed. For alkaline mill tailings a process involving decontamination by a two-stage flocculation and barite treatment was developed. Coagulation was accomplished by use of a commercial water treatment reagent such as ferrous sulfate. By such treatment acid and alkaline mill tailings can be decontaminated sufficiently to meet the specification established by the A.E.C. for waters released to unrestricted areas.

A list of general research subjects investigated and topical reports issued on each is shown in Appendix Table 1. Table 2 shows the general subjects covered in each of the monthly progress reports. 


\section{Analytical}

As analytical methods were developed and as special analytical problems dealing with uranium and related assays were solved, the techniques were recorded and published in the "Raw Materials Development Laboratory. Handbook of Analytical Methods." This manual, which was supplied to interested laboratories throughout the uranium industry and the A.E.C., is available as Technical Information Service Report TID-7002 (Rev。1)。

A great deal of effort was expended on devising an apparatus for the automatic, continual determination of uranium in ion exchange effluents and solvent extraction raffinates. The continuous assaying of ion exchange effluents was successfully demonstrated in the laboratory but extensive engineering would be required to make the apparatus more compact and rugged for use in a mill.

Improving the fluorometric method of uranium determination was a continuing program at the Winchester Laboratory. During 1957 and 1958 the method was improved when the fluorometer was converted to operate without a reference source and an automatic fusion burner was designed and installed. Assistance was provided in making these changes at various mills in this country.

Development of new assaying techniques or revisions of existing methods was necessary when the project program was diverted to radioactive pollution studies. The carrier-free method developed for the determination of radium utilizes a lead sulfate carrier precipitation and an ion exchange separation of lead from radium followed by counting an aliquot dried on a planchet. A similar carrier-free method was also developed for thorium.

A major part of the work of the Analytical Department consisted of routine analyses for the other laboratory departments and special assays for these as well as the Pilot Plant. For several years the number of these determinations averaged 5000 assays per month.

\section{Amenability Testing}

Amenability testing was largely confined to ore testing and new product evaluation. Approximately 375 ores from 62 different locations were studied in the laboratory. The ores were tested to determine optimum conditions for extracting the uranium by acid and alkaline leaching, to obtain information on the rate of filtration and settling, and to determine the characteristics of the pregnant leach solution with respect to recovery of uranium by chemical precipitation, ion exchange, or solvent extraction. Table 3 of the appendix shows the ores studied and references to where the information was reported. 
Product testing was conducted on a variety of products submitted by manufacturers for evaluation. Among such products were new resins and extractants, flocculating and dispersing agents for controlling the physical properties of ore pulps, activated carbon for adsorption of molybdenum and organic material, filter cloths and filter aids, and various miscellaneous chemicals.

\section{Pilot Plant}

The pilot plant program after 1954 was largely two-fold in purpose: (1) Amenability testing of uranium ores from a wide variety of commercial deposits to obtain metallurgical and cost data and (2) to develop and test new processes in pilot plants of sufficient size to permit accurate scale-up to commercial plants. The equipment available for testing ores permitted essentially any desired flowsheet which appeared most efficient for a particular ore from the results of laboratory amenability testing. During most of the project three pilot plants were in continuous operation, each with a capacity of 5 - 15 tons of ore per day. All pilot plants were operated on a 24-hour day, 7-day week basis.

A typical pilot plant amenability test consisted of a 6 weeks to 2 months operation during which time a 500 - 1000 ton representative sample of an ore body or mine was processed. The flowsheet used and operating conditions were largely predicated on earlier laboratory work and the more important variables were also studied in the Pilot Plant. In some cases where very extensive ore bodies indicated that several mills would be built, the ore was tested in two or more pilot plants to obtain complete metallurgical and cost data for comparing economics of various processes. Pilot plant data included over-all uranium recovery, metallurgical data such as optimum grind, leaching conditions and effects of oxidants, filtration or thickening rates, ion exchange data including possible poisoning materials, solvent loading, stripping, and disengagement data, ion exchange column studies, precipitation procedures, and product grade and impurities; as well as total reagent consumption figures for every condition tested. From this information it was possible to calculate reagent costs and to size equipment for commercial mills.

After development of the acid leach - resin-in-pulp process, 19 different ores were tested for their amenability to this method of treatment. As a result six mills were built which used the RIP process, located at Monticello and Moab, Utah; Grants, New Mexico; Tuba City, Arizona, Jeffrey City, Wyoming; and Edgemont, South Dakota. "One mill has been built at Maybell, Colorado, using the countercurrent RIP system and two mills under construction in Wyoming are considering this technique of uranium recovery. 
WIN-115

The Eluex process, a modification of the elution and uranium recovery method connected with RIP was extensively tested in the Pilot Plant and has been put into operation at the Edgemont, South Dakota, mill.

Alkaline leaching of uranium ores in agitated open tanks and in Pachuca tanks, operating at both atmospheric pressure and at relatively small increases in pressure and temperature, was studied during the early part of the pilot plant program. During 1956 and 1957 considerable work was performed on alkaline pressure leaching. A few of the variables studied in the 1000-gallon autoclave included temperature, pressure, air addition, contact time, and agitation. These studies showed that all of these variables were interrelated and each must be considered in selecting optimum operating conditions 。

As a follow-up to the work done at winchester on oxidants for alkaline leaching the copper-ammonia oxidant was tested in the Pilot Plant. Following adoption of copper-ammonia at the Monticello uranium mill results showed that, compared to potassium permanganate, an estimated savings of three dollars per ton of ore treated was realized; one dollar per ton for lower reagent cost and two dollars per ton as a result of increased uranium recovery.

A circuit was installed to investigate continuous precipitation of uranium with caustic from pregnant alkaline liquors. Another method of precipitating alkaline liquors, by hydrogen reduction in the presence of nickel catalyst, was also tested.

Results of pilot plant work on some fourteen different types of ores in the alkaline leaching process were a contributing factor in the building of seven mills incorporating sodium carbonate bicarbonate dissolution processes. Four of these mills are located at Grants, New Mexico, with other mills at Monticello, Utah; Canon City, Colorado; and Riverton, Wyoming. Pressure leaching, copper-ammonia oxidation, and continuous precipitation techniques have all been employed in one or more of these mills.

The pilot testing of the alkaline leach - resin-in-pulp process lead to the conversion of the A.E.C. Monticello mill and to the change of a portion of the Uranium Reduction Company mill to this recovery method. Alkaline leaching followed by CCD for liquidsolid separation and colum ion exchange was also tested and found to be technically possible. Acid leach - CCD - IX plants could be easily converted to the process should the need arise.

Another combined process tested in the Pilot Plant included flotation of the lime portion of high-lime ore followed by alkaline leaching of the high-lime-fraction and acid leaching of the flotation tails, or low-lime fraction. 
Ores from the Big Indian Wash area of Utah, Ambrosia Lake in New Mexico, and Gas Hills area of Wyoming were treated in the acid leach - CCD - ion exchange column pilot plant. Mills using this recovery method are now located at Uravan, Colorado, east of Riverton, Wyoming, and at Ford, Washington.

Solvent extraction studies at the Pilot Plant included development work on the Eluex process; studies on equipment design and process flowrates in external and internal mixer-settler units and pulse columns, evaluation of amines and organic - phosphoric acids, and techniques for control of molybdenum. The combined research effort on solvent extraction of uranium from leach liquors by the several A.E.C. research contractors and independent research organizations resulted in a trend to this recovery method in a large number of the more recently built uranium mills. Mills using solvent extraction are located at Shiprock and Grants, New Mexico; Grand Junction, Gunnison, Rifle, and Durango, Colorado; Mexican Hat and Salt Lake City, Utah; Riverton, Wyoming; and Lakeview, Oregon。As mentioned previously, the Edgemont, South Dakota, mill uses solvent extraction in connection with the Eluex process.

A major effort at the Pilot Plant during 1957 was the testing and development of a flowsheet for the recovery of uranium from the lignites of North and South Dakota. Nearly 2000 tons of 1ignite were consumed in these tests and the results established the Dakota lignites as a reserve of uranium which can be exploited when and if future economics warrant. Although the data and techniques developed during the test work have not been incorporated in a mill, they have been used extensively by private industry and the A.E.C. for evaluating the economics of the recovery of uranium from Dakota lignites.

During the course of the operation of the Grand Junction Pilot Plant approximately 30,000 tons of ore from 40 different mines or locations throughout Western United States were tested. Yellow cake production during the period amounted to 138,500 pounds of contained $\mathrm{U}_{3} \mathrm{O}_{8}$. The analytical laboratory at Grand Junction, which assayed all mill samples except for special determinations made at the Winchester Laboratory, averaged approximately 8000 assays per month. A metallurgical laboratory handled metallurgical problems encountered in the Pilot Plant and performed metallurgical tests which were not practical to do at Winchester. These included leach tests on pilot plant ore shipments when received, screen analyses, settling and filtration tests and evaluation of mill flocculents, ion exchange loading and elution tests, solvent shakeout tests, and precipitation studies on mill liquors.

During the past year a field office has been maintained at Grand Junction in connection with studies on the radioactive 
decontamination of uranium mill tailings. Work of this office included sampling tailings from the commercial mills, sampling programs in a group of mills using different flowsheets for the purpose of making radium and thorium balances around these mills, and pilot plant decontamination tests to evaluate methods developed at Winchester.

\section{Mill Assistance}

In the course of the project technical assistance was given to uranium mills in Australia, South Africa, Canada, and the Belgian Congo. Engineers and chemists from the Raw Materials Development Laboratory spent considerable time at various individual mills in these countries assisting with leaching, ion exchange, and analytical problems.

During the period that many new uranium mills were being built in the United States and technical, operating, and analytical personnel were learning new and quite different techniques, National Lead personnel from the Laboratory and Pilot Plant gave assistance to these companies. Laboratory personnel from most of the new mills went through training programs at either the Winchester or Grand Junction laboratories. These varied from a few days to several weeks and gave the mill analysts a background in uranium assaying and allied determinations.

Several mills sent operating crews to the Pilot Plant to learn established operating techniques, particularly in connection with the resin-in-pulp ion exchange circuit. Pilot plant engineers, chemists, and operators also assisted seven mills during the early weeks of start-up operations. At a time when it was necessary to get new mills into production as quickly and efficiently as possible and at a time when new metallurgical techniques such as ion exchange were relatively new in this country, this assistance was considered by the private mills to be very helpful.

As new analytical techniques, particularly in connection with the fluorometric uranium analysis, were developed they were passed on to mill personnel and in many cases Winchester or Grand Junction technicians personally helped change equipment or assisted in the adoption of these techniques.

As a great deal of the technology used in the uranium industry was developed by the raw materials development project, the demand for personnel trained in the laboratory and pilot plant was great. In the final analysis the greatest contribution of the project to the atomic energy program may well have been the large number of technical personnel who were trained on the project. 


\section{DESCRIPTION OF FACILITIES}

\section{Winchester Laboratory}

The research facilities of the Raw Materials Development Laboratory were located at Winchester, Massachusetts, a residential community about 15 miles from Boston. The laboratory building, constructed in 1952, is a modern, single-story, cement block and brick building with a floor area of 31,400 square feet (Figure 1). The building was divided into approximately thirty laboratories, work areas, shops and offices and was equipped and staffed for conducting a wide variety of metallurgical, chemical and analytical investigations. Figure 3 shows a floor plan of the laboratory. A small test plant was available for continuous unit process testing. Well equipped machine and instrument shops provided for the maintenance and construction of standard and specialized equipment.

The laboratory was divided into three departments: Metallurgical, Chemical, and Analytical. The laboratory was equipped for investigations into acid and alkaline leaching techniques, ion exchange, solvent extraction, and precipitation processes. Facilities were also available for conducting mineralogical studies, flotation, gravity concentration, magnetic and electrostatic separations. A we11 equipped crushing and sampling laboratory assured careful preparation and sampling of the ores received for testing. Figure 4 and 5 show the mineral dressing laboratory and the sample preparation room, respectively.

The analytical facilities contained besides the usual equipment for wet-chemical analyses a complete emission spectrograph laboratory, spectrophotometers and polarographs of both the recording and non-recording types, radiometric counting equipment, and other modern analytical instruments. Figures 6 through 9 show views of some of the chemical and analytical facilities.

\section{Grand Junction Pilot Plant}

The Grand Junction Pilot Plant was located at the south end of the A.E.C. Compound on the bank of the Gunnison River. It included two large mill buildings, a crushing and sampling plant building, office and laboratory building, warehouse, maintenance shop, and the necessary areas for stockpiling ore and tailings pond (Figure 2). The Pilot Plant contained; wherever possible, standard types and sizes of equipment so as to minimize the problem of scale-up so commonly encountered in translating the data obtained from pilot plants to full-scale operating plants. The Pilot Plant contained a feed preparation plant where the ores were weighed, crushed, sampled, and stored and four primary leaching and processing circuits; 
WIN-115

-16 -

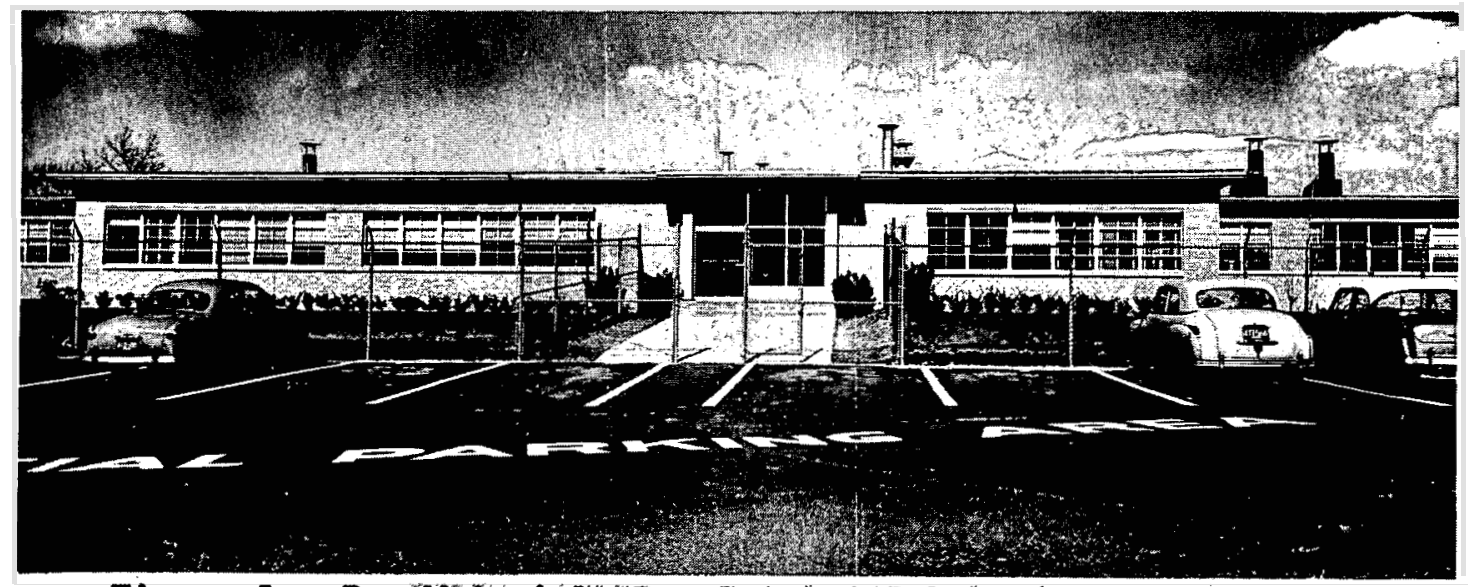

Figure 1. Raw Materials Development Laboratory Holton Street, Winchester, Mass.

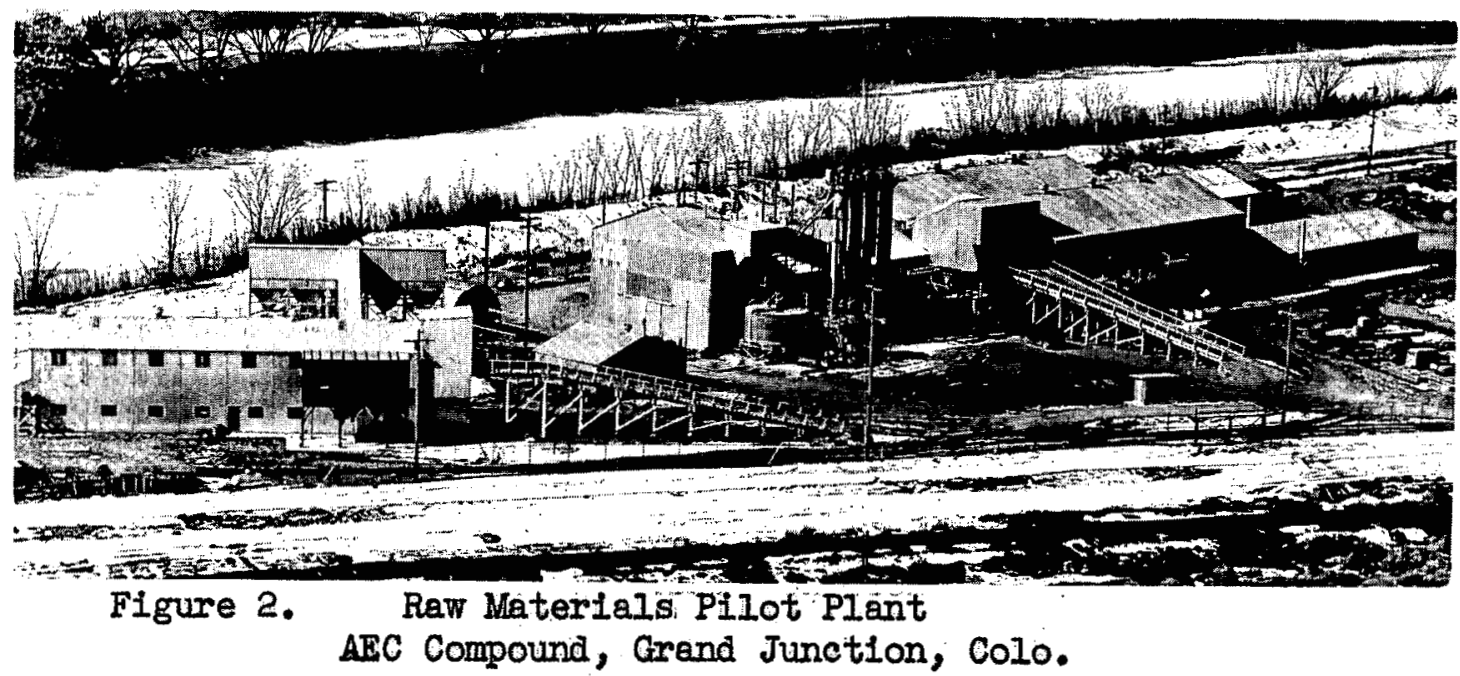




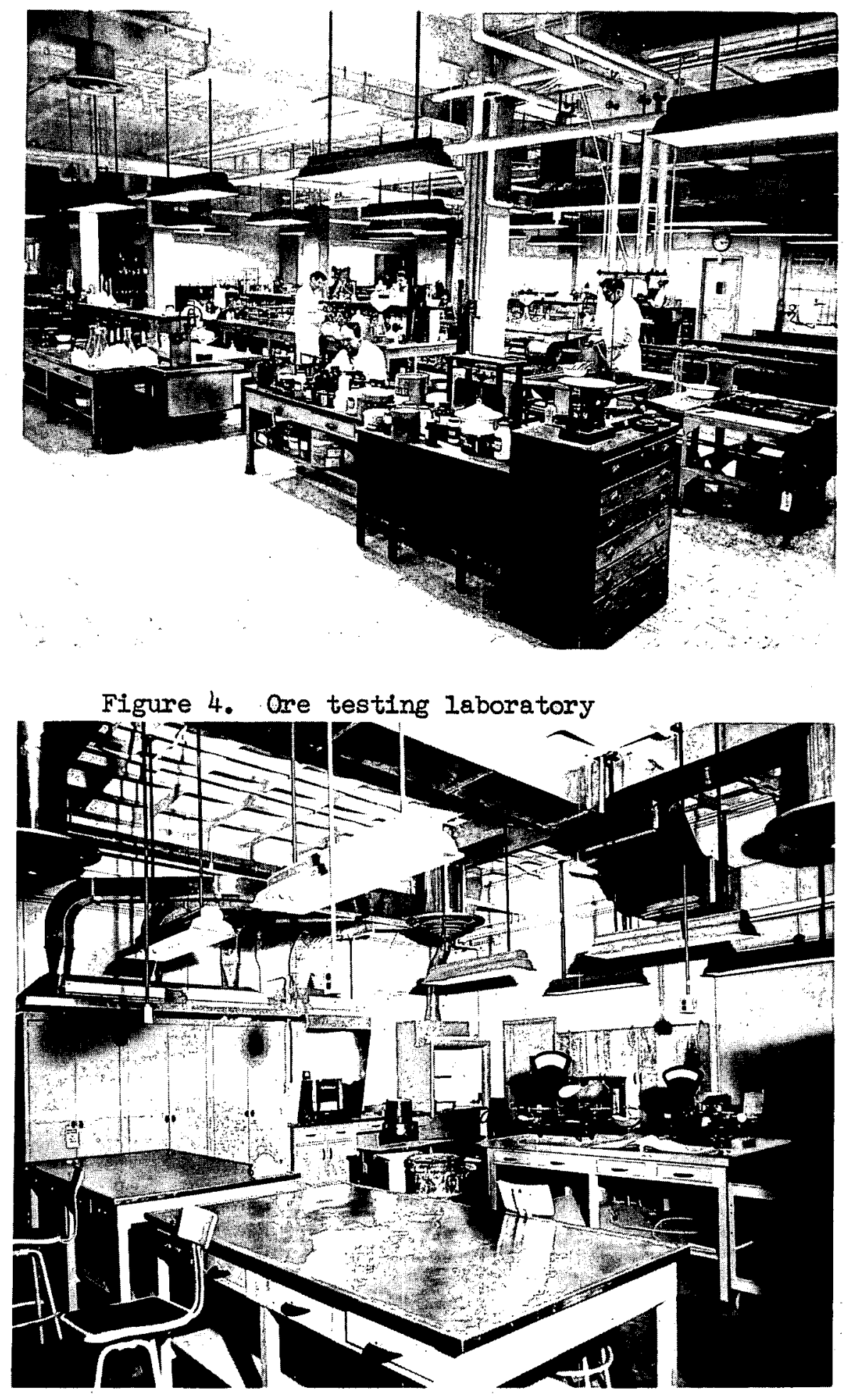

Figure 5." Sample preparation room 

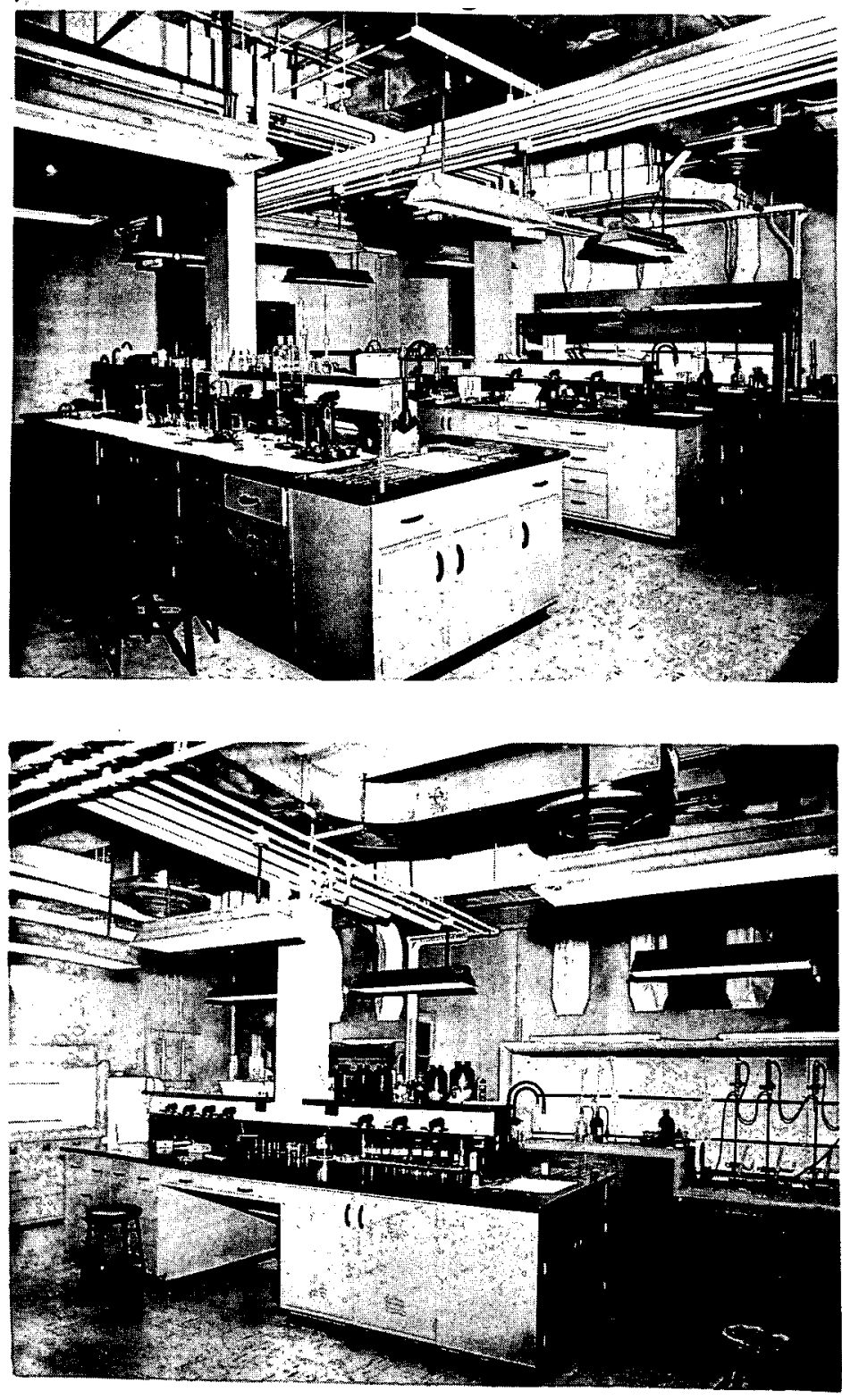

Figure 6. Low-U Laboratory

Figure 8. High-U Laboratory
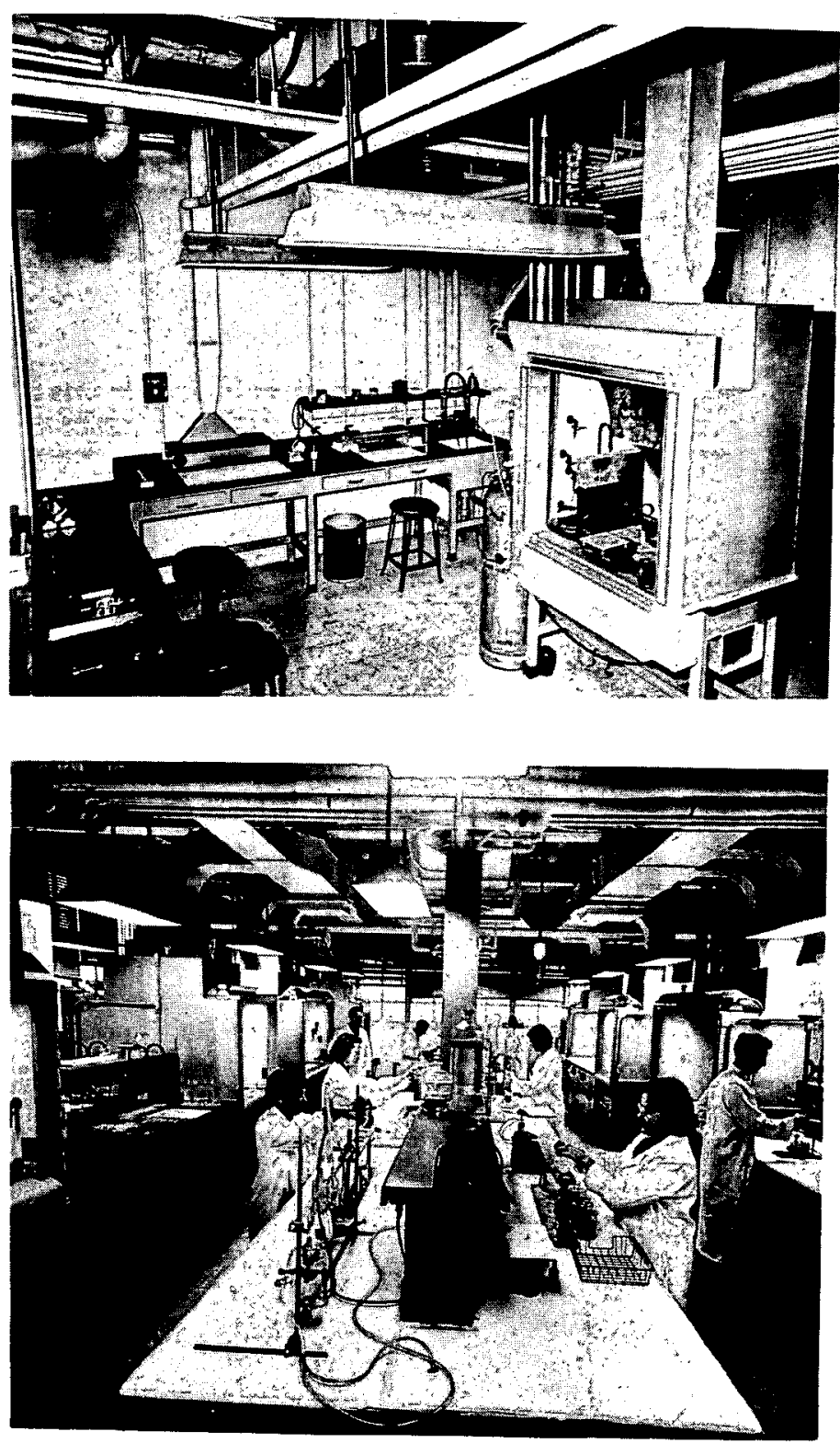

占蛋

Figure 7. Fluorometric Laboratory

Figure 9. Analytical Laboratory 
carbonate leach - filtration, carbonate leach - resin-in-pulp, acid leach - resin-in-pulp, and acid leach - CCD - column ion exchange or solvent extraction.

The carbonate leaching circuits provided for the study of leaching by means of mechanical or air agitation at either atmospheric or elevated pressures. The acid leaching circuits were also equipped for mechanical or air agitation. Recovery of uranium in the acid circuits was accomplished by the resin-in-pulp process or by column ion exchange or solvent extraction from clear solutions obtained by the use of thickeners or filters or combinations of the two. The solvent extraction circuits included both mixer settlers and pulse columns. Auxiliary milling and processing equipment included a flotation circuit and a FluoSolids roaster, as well as miscellaneous tanks, agitators, and filters. A we 11 equipped Analytical Department performed the large number of assays required in the operation of the various circuits, and a metallurgical laboratory conducted metallurgical research and process development studies connected with the operation of the pilot plant.

Views of the interior of the Pilot Plant are shown in Figures 10 through 13. Flowsheets of various circuits are presented in Figures 14 through 19. 


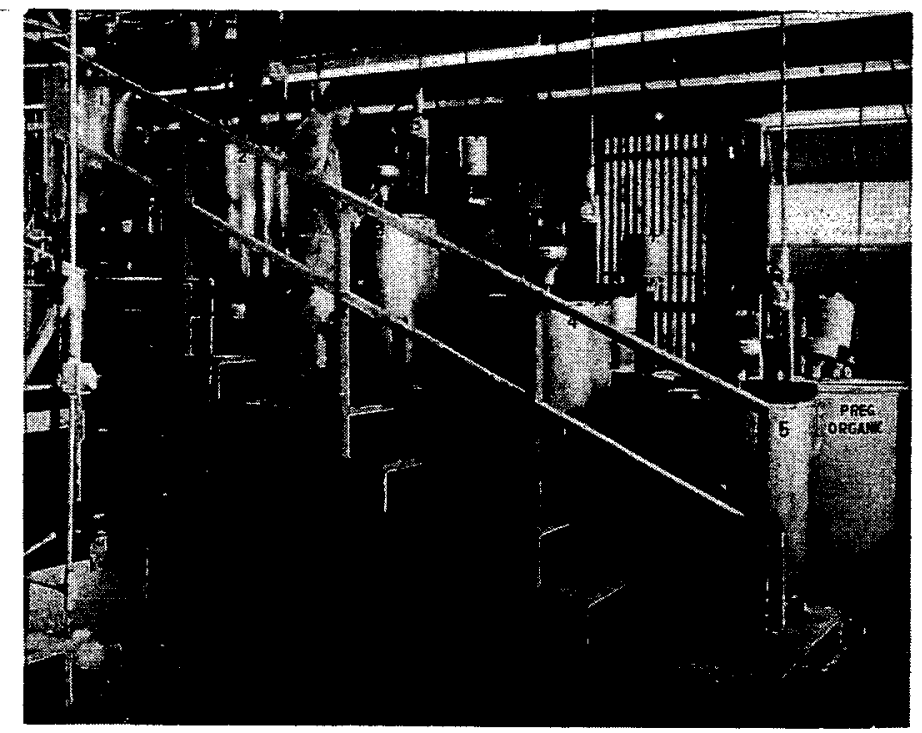

FIgure 10. Solvent extraction pilot plant

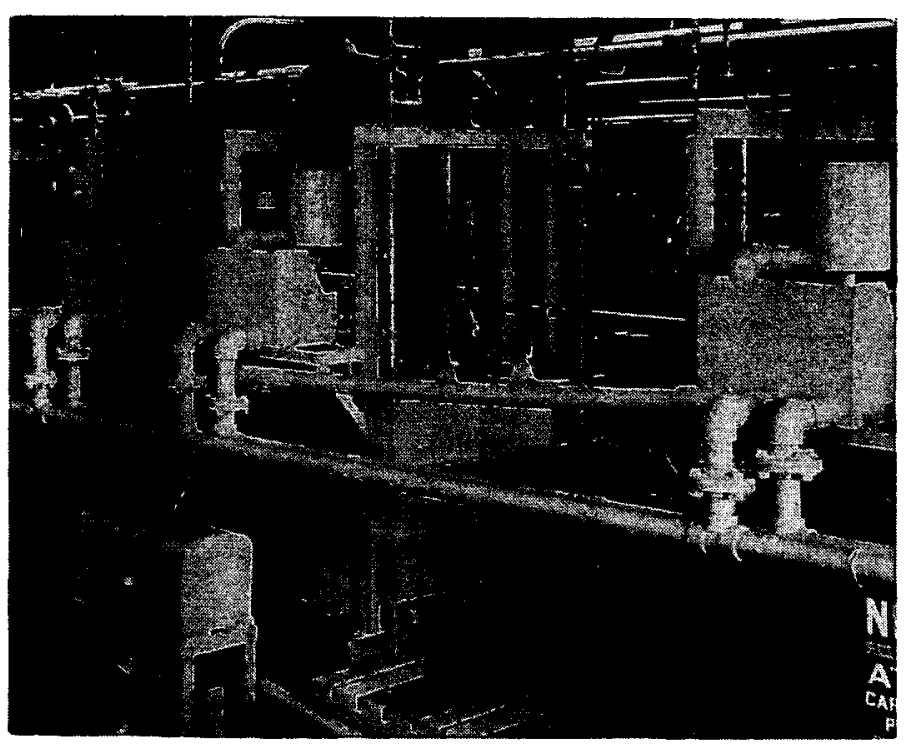

Figure 12. RIP Pilot Plant

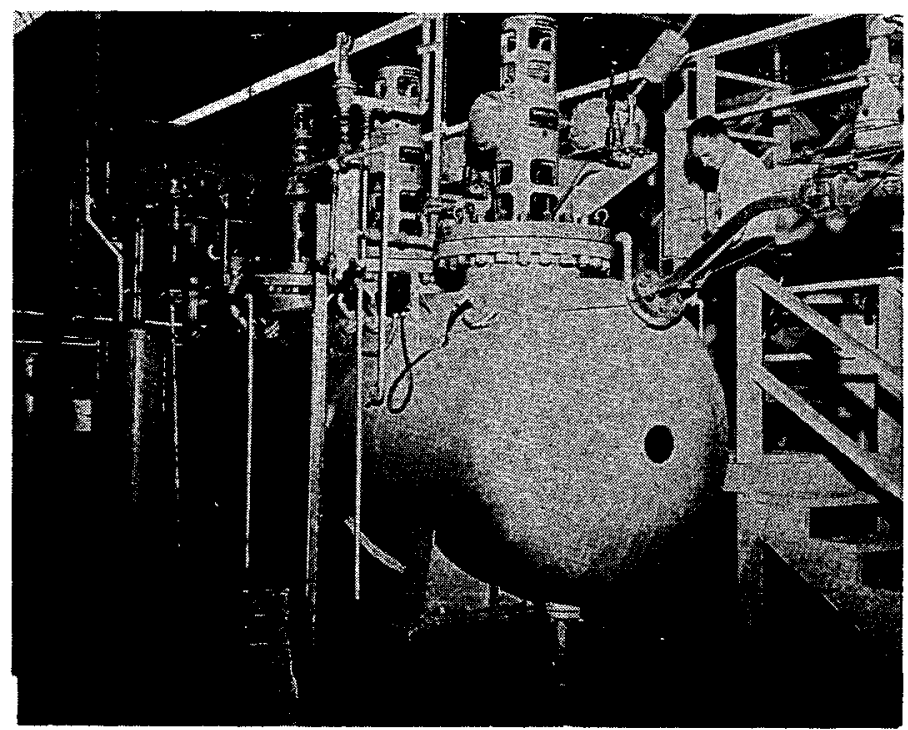

Figure 11. Alkaline leaching autoclave

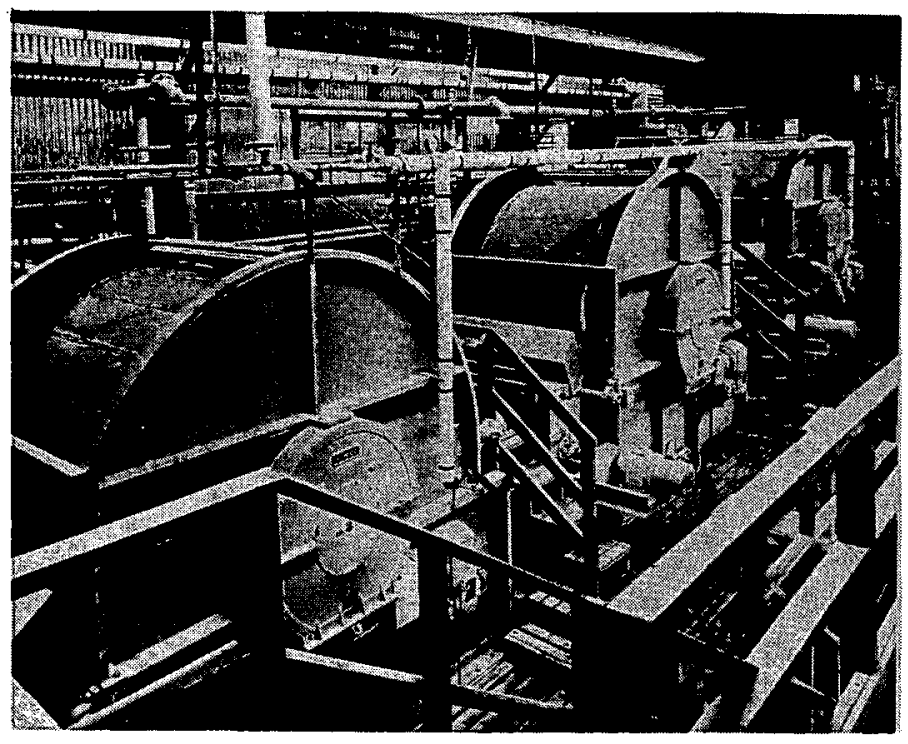

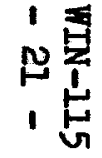




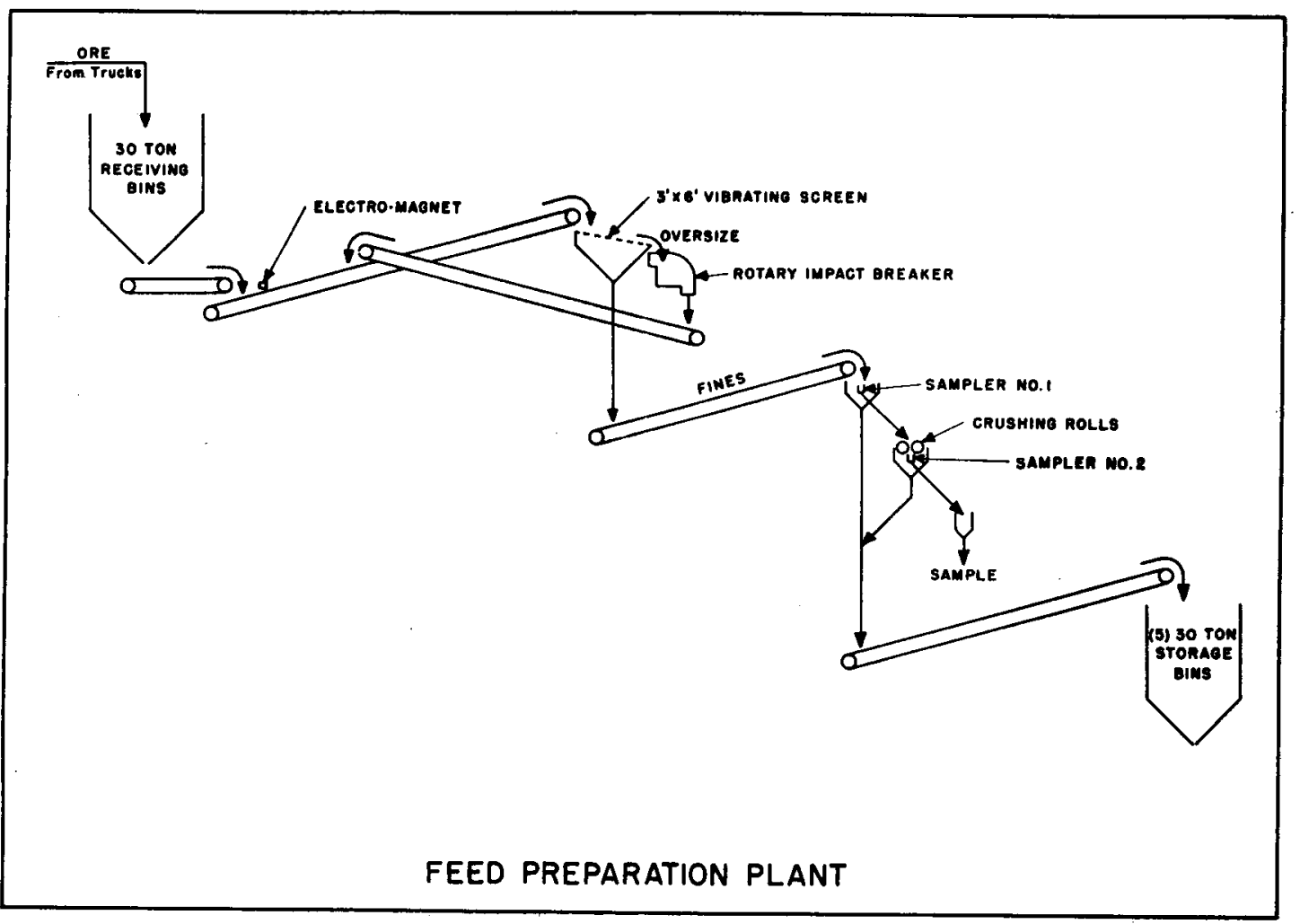

Figure 14

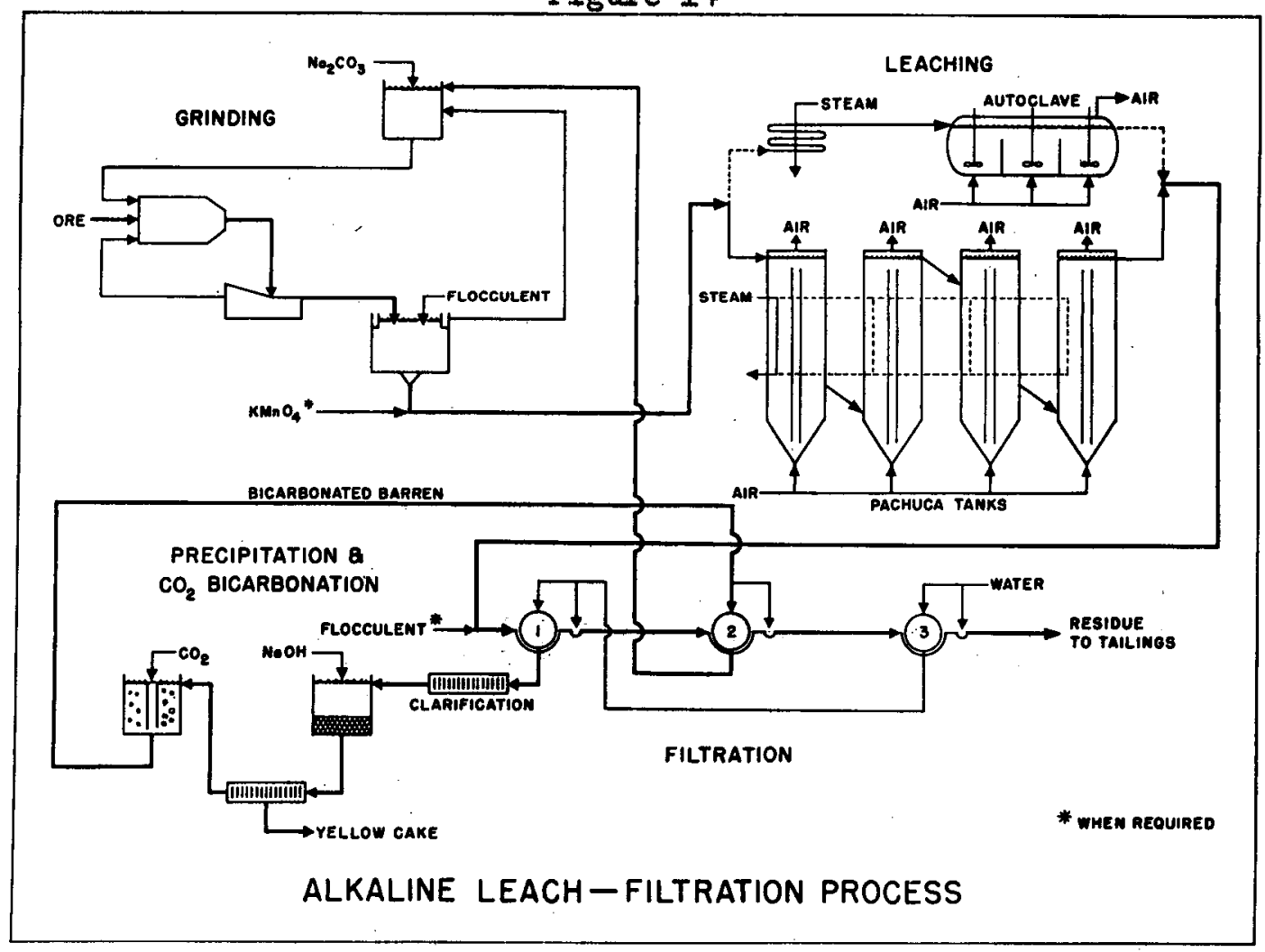




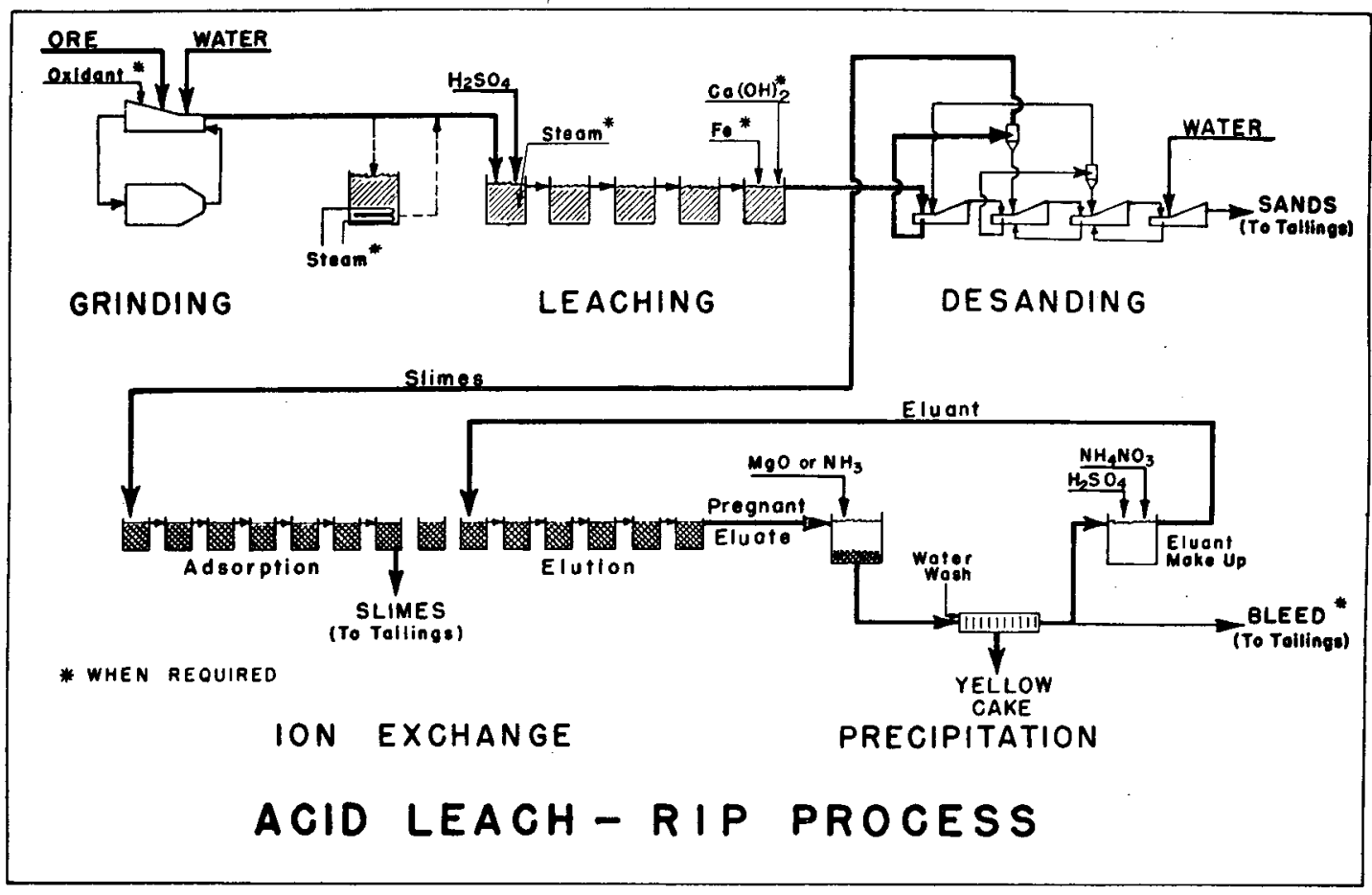

Figure 16

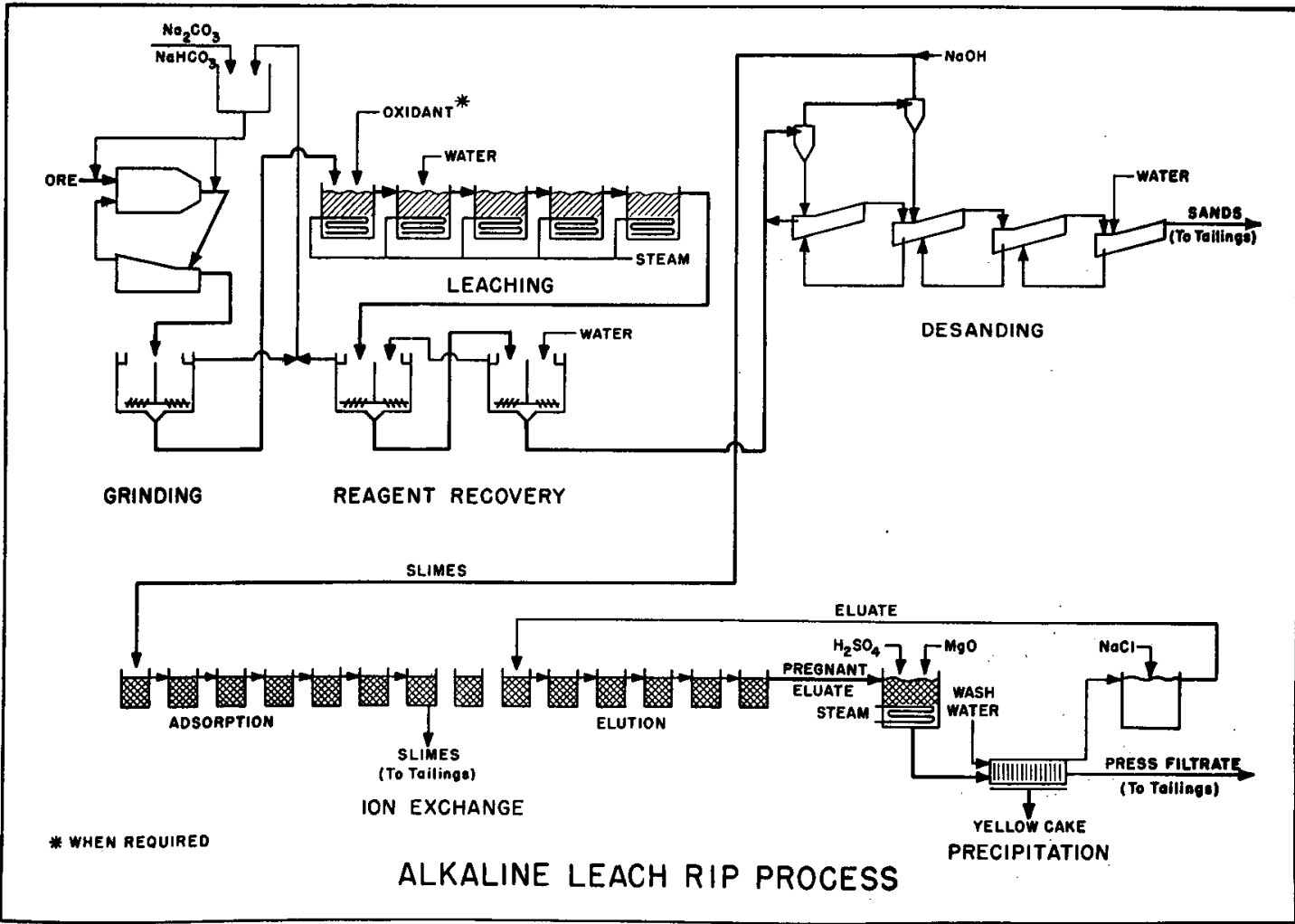

Figure 17 

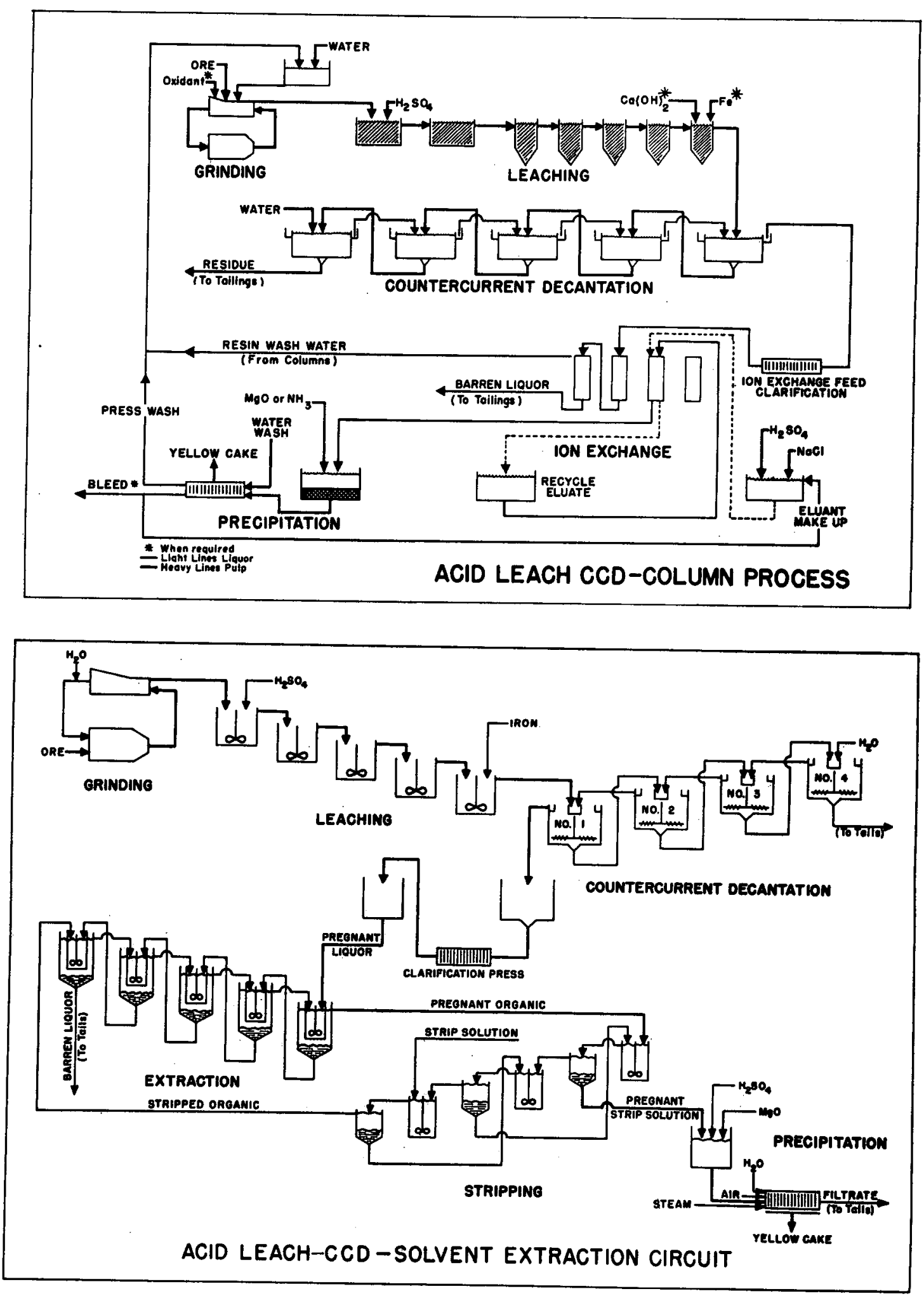

Figures 18 and 19 
WIN-115

\section{PERSONNEL}

The program was initiated in July 1954 under the direction of J. S. Breitenstein, Technical Director. Mr. C. K. McArthur became Technical director in July 1957. The technical operation of the Winchester Laboratory was directed by $R$. J. Woody and the Grand Junction Pilot Plant was managed, in order, by R. F. Hollis, C. K. McArthur, and R. G. Beverly. The two units operated essentially as distinct facilities with close liaison maintaining a coordinated approach to the technical problems. Dr. M. A. Desesa was Head of the Analytical Section of the Winchester Laboratory, G. W. Clevenger and D. R. George headed the Metallurgy Department, and $\mathrm{Dr}$. A. M. Ross and H. J. Petrow were in charge of the Chemical Department. Department heads at the Grand Junction Pilot Plant included J. Q. Jones, A. W. Griffith, J. N. Kalahar, J. D. Crozier, and W. D. Charles.

Presented in Figures 20 and 21 are the organization charts as they appeared in January 1, 1955 and January 1, 1958. 



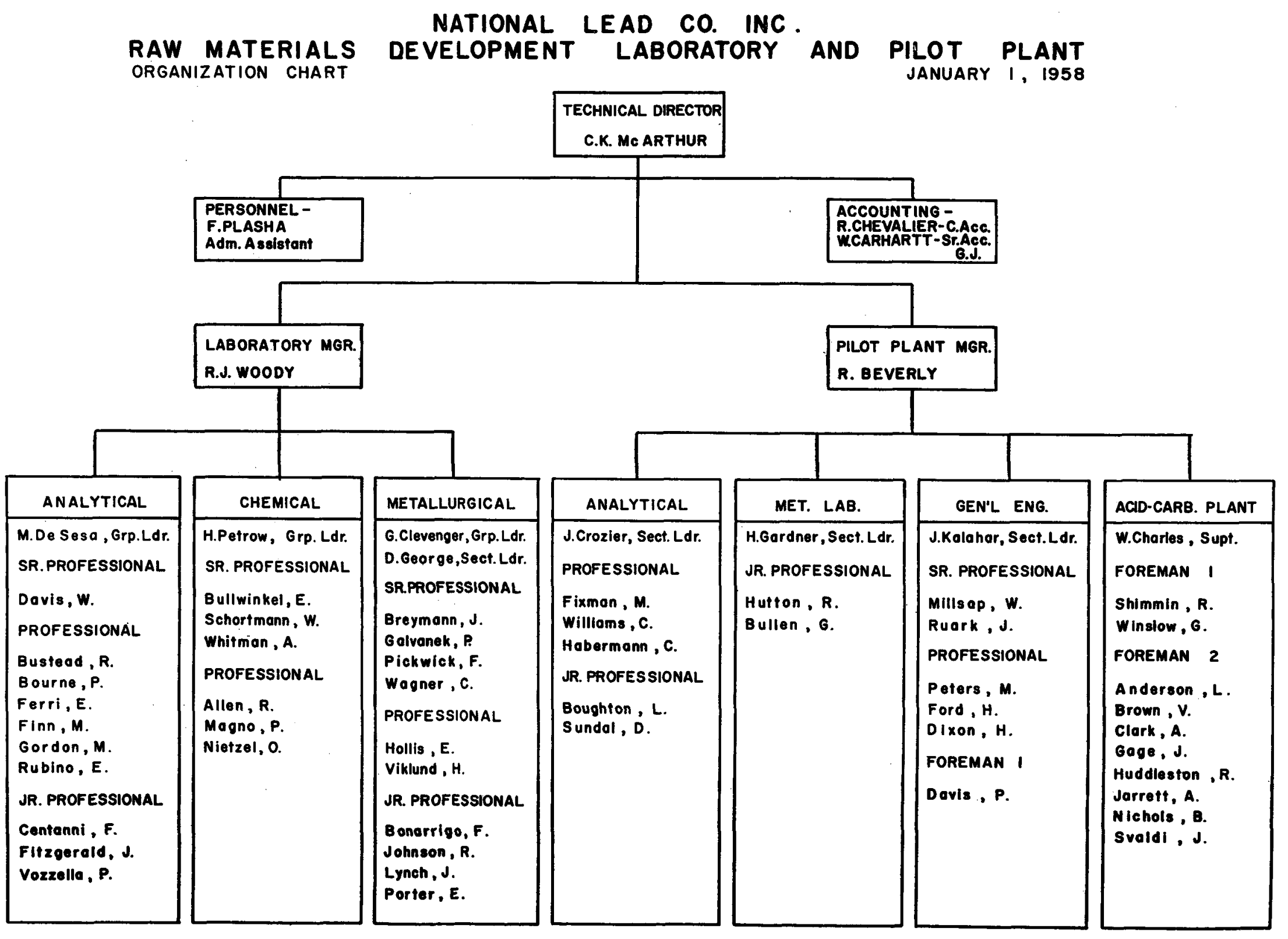

喜薏

Figure 21 
$\underline{\text { Publications }}$

Allen, R. J., and DeSesa, M. A., "New and Improved Analyses for Tri-NButyl Phosphate," Nucleonics, 15:10, pp. 88-98, Oct. 1957.

Allen, R. J., Petrow, H. G., and Magno, P. J., "Precipitation of Uranium Tetrafluoride from Aqueous Solution by Catalytic Reduction," Industrial and Engineering Chemistry, 50, pp. 1748-1749, Dec. 1958.

Allen, R. J., Petrow, H. G., and Whitman, A., "Preparation of Dense, Metal Grade Uranium Tetrafluoride from Uraniferous Ores," Peaceful Uses of Atomic Energy, Second International Conference, Geneva, Sept. 1958, Vol. 4, p。121.

Beverly, R. G., Griffith, A. W., and Millsap, W. A., "Atmospheric vs Pressure Leaching of Uranium Ores," Journal of Metals, 9:6, pp. 746-751, June 1957 。

Beverly, R. G., Griffith, A.W., and Millsap, W. A., "Atmospheric vs . Pressure Leaching of Uranium Ores," Mining Engineering, 9:9, pp. 982-988, Sept. 1957.

Beverly, R. G., and Charles, W.D., "Pilot Plant Alkaline Leaching of Uranium Ores," Peaceful Uses of Atomic Energy, Proceedings of the Second International Conference, Geneva, Sept. 1958, Vo1。3, pp。326-332.

Centanni, F.A., Ross, A. M., and DeSesa, M. A., "Fluorometric Determination of Uranium," Analytical Chemistry, 28:11, pp. 1651-1657, Nov. 1956.

Charles, W. D., "Recent Developments in the Study of Uraniferous Lignite Treatment," Recent Developments in Uranium Milling Technology, Uranium Institute of America, Grand Junction, Colorado, pp. 59-74, May 1958.

DeSesa, M. A., "Analyses of Uranium Ores," Part II, Chapter 3, Uranium Ore P.rocessing, John W. Clegg and Dennis D. Foley, Battelle Memorial Institute, Addison-Wesley Publishing Company, Inc., Pp .65-88, Sept. 1958.

DeSesa, M. A., Magno, P. J., Gardner, H. E., and Dickerman, E., "Cupric Ammonium Reagent as an Oxidant in the Carbonate Leaching of Uraniferous Ores," Peaceful Uses of Atomic Energy, Proceedings of the Second InterNationa1 Conference, Geneva, Sept. 1958, Vol. 3, pp. 342-345.

George, D. R., "Mineralogy of Uranium and Its Relationship to Hydrometallurgical Processing," Chapter 4, Uranium Ore Processing, John W. Clegg and Dennis D. Foley, Battelle Memorial Institute, Addison-Wesley Publishing Company, Inc., pp.89-102, Sept. 1958.

Hollis, R. F., and McArthur, C. K., "The Resin-In-Pulp Method for Recovery of Uranium," Mining Engineering, 9:4, pp . 443-449, Apri1 1957 .

Hollis, R. F., and McArthur, C. K., "The Resin-In-Pulp Method for Recovery of Uranium" Peaceful Uses of Atomic Energy, Proceedings of the First International Conference, Geneva, 1956, Vo1。8, pp. 54-63. 
Publications Continued

"National Lead Company, Inc. - AEC Pilot Plant (Annual Review)," 1957 Mining Yearbook, Denver, Colorado, pp. 56-57, Feb. 1957.

"National Lead Company, Inc. - AEC Pilot Plant (Annual Review)," 1958 Mining Yearbook, Denver, Colorado, pp. 60-61, Feb. 1958.

"National Lead Company, Inc. - AEC Pilot Plant (Annual Review)," 1959 Mining Yearbook, Denver, Colorado, p. 45, Feb. 1959.

Newman, L., LaFleur, W. J., Brousaides, F. J., and Ross, A. M., "A Spectrophotometric Investigation of Vanadium (V) Species in Alkaline Solutions," Journal of the American Chemical Society, 80, pp. 4491-4495, Sept. 1958 .

Newman, L., and Quinlan, K. P., "A Spectrophotometric Investigation of Vanadium (V) Species in Acidic Solutions," Journal of the American Chemical Society, 81, pp. 547-549, Feb. 1959.

Nietze1, 0. A., Wessling, B.W., and DeSesa, M. A., "Ion Exchange Spectrophotometric Determination of Thorium," Analytical Chemistry, $30: 7$, pp. 1182-1185, July 1958 .

Nietze1, 0. A., and DeSesa, M. A., "Spectrophotometric Determination of Tétrathionate," Analytical Chemistry, $27: 1$, pp. 1839-1841, Nov. 1955.

Nietze1, 0. A., and DeSesa, M. A., "Spectrophotometric Determination of Uranium with Thiocyanate in Acetone - Ethyl Acetate - Water Medium," Peaceful Uses of Atomic Energy, Proceedings of the First International Conference, Geneva, 1956, Vol. 8, pp. 320-324.

Nietze1, 0.A., and DeSesa, M.A., "Spectrophotometric Determination of Uranium with Thiocyanate in Butyl Cellosolve-Methyl Isobutyl KetoneWater Medium," Analytical Chemistry, 29:5, pp. 756-759, May 1957.

Porter, E. S., and Petrow, H. G., "Recovery of Uranium from Lignites," Mińing Engineering, 9:9, pp. 1004-1006, Sept. 1957.

Porter, E. S., and Petrow, H. G., "Uranium Recovery from Lignite," Chapter 12, Part 4, Uranium Ore Processing, John W. Clegg and Dennis D. Foley, Battelle Memorial Institute, Addison-Wesley Publishing Company, Inc., pp. 390-396, Sept. 1958.

Quinlan, K. P., and DeSesa, M. A., "Spectrophotometric Determination of Phosphorus as Molybdovanadophosphoric Acid," Analytical Chemistry, $27: 10$, pp. 1626-1629, Oct. 1955 .

Ross, A. M., "Solvent Extraction - Newcomer to the Colorado Plateau," Mining Engineering, 9:9, pp. 997-1000, Sept. 1957.

Schortmann, W. E., and DeSesa, M. A., "Kinetics of the Dissolution of Uranium Dioxide in Carbonate-Bicarbonate Solutions," Peaceful Uses of Atomic Energy, Proceedings of the Second International Conference, Geneva, Sept.1958, Vol. 3, pp. 333-341。

Woody, R. J. and George, D. R., "Acid Leaching of Uranium Ores," Chapter 6, Uranium Ore Processing, John W. Clegg and Dennis D. Foley, Battelle Memorial Institute, Addison-Wesley Publishing Company, Inc., pp. 115-152, Sept. 1958. 
Summary of Disposition of Invention Reports

Winchester Laboratory

\begin{tabular}{|c|c|c|c|c|}
\hline $\begin{array}{l}\text { AEC Case } \\
\text { Number }\end{array}$ & $\begin{array}{l}\text { Contractor's } \\
\text { Number }\end{array}$ & Inventor (s) & Iitle & Disposition \\
\hline- & $W I N-P-1$ & R. J. Woody & $\begin{array}{l}\text { Apparatus for Continuous Countercurrent } \\
\text { Ion Exchange }\end{array}$ & $\begin{array}{l}\text { Disclosure inactivated } \\
\text { at Winchester }\end{array}$ \\
\hline$S-13,828$ & $W I N-P-2$ & H. G. Petrow & $\begin{array}{l}\text { Process for Recovery and Concentration } \\
\text { of Uranium }\end{array}$ & $\begin{array}{l}\text { S.N. - } 626,834 \text {. Advised } \\
\text { by AEC that prior art } \\
\text { interferes }\end{array}$ \\
\hline$s-14,879$ & WIN-P-3 & P. Galvanek, Jr. & $\begin{array}{l}\text { A Solvent Leaching Process for the } \\
\text { Recovery and Concentration of Uranium }\end{array}$ & $\begin{array}{l}\text { U. S. Patent issued on } \\
2 / 24 / 59-\text { No. } 2,875,023 \text {. }\end{array}$ \\
\hline$S-13,826$ & $W I N-P-4$ & F. A. Centanni & $\begin{array}{l}\text { Flux for Use in the Fluorimetric } \\
\text { Determination of Uranium }\end{array}$ & $\begin{array}{l}\text { Subject material handled } \\
\text { by Technical Publication } \\
\text { with AEC approval }\end{array}$ \\
\hline$S-15,515$ & WIN $-\mathrm{P}-5$ & R. J. Woody & $\begin{array}{l}\text { An integrated Recycle Process for the } \\
\text { Recovery of Uranium from Ores }\end{array}$ & $\begin{array}{l}\text { Disclosure submitted } \\
\text { to AEC }\end{array}$ \\
\hline$s-15,981$ & WIN-P-6 & H. F. Wilson & $\begin{array}{l}\text { Alkaline Ion Exchange Process for Re- } \\
\text { covery of Uranium and Vanadium }\end{array}$ & $\begin{array}{l}\text { U. S. Patent issued on } \\
7 / 1 / 58-\text { No. } 2,841,468\end{array}$ \\
\hline$s-16,345$ & WIN-P-7 & P. Galvanek & Multiple Discharge Pump & $\begin{array}{l}\text { Advised by AEC that prior } \\
\text { art interferes - no } \\
\text { filing action }\end{array}$ \\
\hline - & WIN-P-8 & H. G. Petrow & Uranium Recovery Process (Eluex Process) & $\begin{array}{l}\text { Disclosure Inactivated } \\
\text { at Winchester }\end{array}$ \\
\hline - & WIN-P-9 & R. J. Woody & Ion Exchange Process & $\begin{array}{l}\text { Disclosure Inactivated } \\
\text { at Winchester }\end{array}$ \\
\hline
\end{tabular}


Sumnary of Disposition of Invention Reports

Winchester Laboratory

(cont'd)

\begin{tabular}{|c|c|c|c|c|}
\hline $\begin{array}{l}\text { ABC Case } \\
\text { Number }\end{array}$ & $\begin{array}{l}\text { Contractor's } \\
\text { Number }\end{array}$ & Inventor (s) & Titze & Disposition \\
\hline$s-16,460$ & WIN-P-10 & $\begin{array}{l}\text { P. J. Magno and } \\
\text { M. A. Desesa }\end{array}$ & Carbonate OxIdants & Disclosure submitted to AEC \\
\hline$s-16,468$ & WIN-P-II & $\begin{array}{l}\text { R. J. Woody, } \\
\text { F. A. Howland, and } \\
\text { E. T. Hollis }\end{array}$ & Continuous IX Colum & $\begin{array}{l}\text { Advised by ARC that no } \\
\text { fling action will be taken }\end{array}$ \\
\hline- & WIN-P-12 & W. D. Charles & Uranium Recovery Process & $\begin{array}{l}\text { Disclosures inactivated } \\
\text { at Winchester }\end{array}$ \\
\hline- & WIN-P-13 & B. W. Wessling & $\begin{array}{l}\text { Apparatus for Continuous } \\
\text { Uranium Analysis }\end{array}$ & $\begin{array}{l}\text { Disclosure inactivated } \\
\text { at Winchester }\end{array}$ \\
\hline - & WIN-P-14 & L. Newman & Preparation of $\mathrm{UF}_{4}$ & $\begin{array}{l}\text { Disclosure inactivated } \\
\text { at Winchester }\end{array}$ \\
\hline$S-16,594$ & WIN-P-15 & $\begin{array}{l}\text { R. J. Allen and } \\
\text { H. G. Petrow }\end{array}$ & Process for $\mathrm{UF}_{4}$ Production & $\begin{array}{l}\text { Application flied by } A B C \text {, } \\
\text { S. N. } 801,977(48)\end{array}$ \\
\hline$s-18,066$ & WIN-P-16 & J. T. Lynch & Electrolytic Oxidation Method & $\begin{array}{l}\text { Advised by ABC that no } \\
\text { filing action will be taken }\end{array}$ \\
\hline
\end{tabular}


$\underline{A} \underline{P} \underline{P} \underline{E} \underline{N} \underline{D} \underline{X}$ 
Table 1

Classification of Topical Reports by Subject

$$
\text { July 1, } 1954 \text { - June 30, } 1999
$$

Symbol

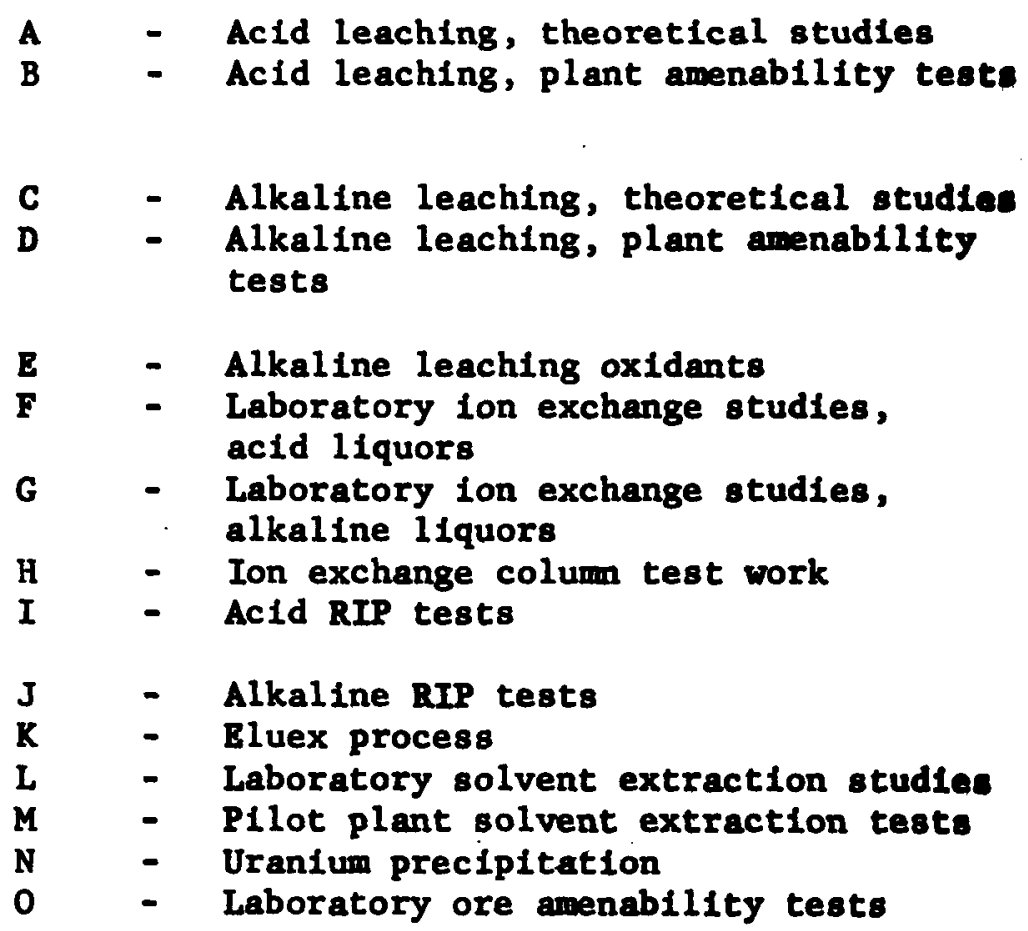

- Analytical, uranium

- Analytical, nonuranium

- Flotation

- Molybdenum

- Vanadium

- Solvent leaching

- Roasting

- Lignites and coals

- Ammonia carbonate leaching

- Green salt (UF4)

- Pollution, chemical and radioactive

- Countercurrent RIP

- Uranium recovery from tails and scrap

- Higgins contactor
Toplcal VIM No.

3,29

$5,12,18,23,32,35,40$, $42,44,47,60,69,70$, $72,76,78$

$3,73,89,103,104$

$19,20,39,45,57,66,67$, $77,79,80,82,83,84,106$, $107,108,109,110$

86

$4,9,15,26,27$

88

$26,44,76,78,84,109$

$5,12,18,23,32,35,40$, $42,47,60,70,78$

$11,17,39,77,82,83,88$ 28,75

$24,28,30,54,61$

$69,72,81$

$13,16,21$

$1,3,6,8,14,25,36,38$, $41,49,50,51,54,56,58$, $59,64,65,68,71,74,87$, $91,92,96,97$

$34,43,46,63$

$7, .10,52,62,85$

2

$27,48,53$

16,55

31,100

54,81

$33,54,81$

37

90,95

$99,101,111,112,113,114$ 102,105

22,98 
WI-115

Table 2

Uranlum Ores Tested with Toplcal and Progress Report References

July 1, 1954 - June 30, 1959

Ore and. Location

Ambrosia Lake, New Mexico

Arrowhead, Arlzona

Atascosa County, Texas

Austin Lignite, Texas

Blind River, Canada

Bog Type, California

Cal-Uranium, Utah

Columbian Samples, So. America

Copper City Mill Tail, Arizona

Cord, E. L., Jen-Jackie Claim, Utah

Dakota Lignites

Dominion Reefs, So. Africa

Duval County, Texas

Dysart Shaft, New Mexico

Dysons' Rum Jungle, Australla

Edgemont, So. Dakota

Four Corners, Utah

Gas Hills, Wyoming

Globe, Arizona

Globe Mining Co., Gas H11ls, Wyoming

Happy Jack Mine, Utah

Hecla Mining Co., Utah

Hidden Splendor Mine, Utah

Holly Minerals Co. (Sec. 14), New Mexico

Homestake North Alfce, Utah

Homes take (Sec. 32), New Mexico

Jack Pile Mine, New Mexico

Rarnes County, Texas

LaBajada, New Mexico

Lakeview Mining Co., Lucky Lass and

White King claims, Oregon

Lasalle, Colorado

La Sal, Utah

Lehigh Coal and Navigation, Pa.

L1ttle Beaver, Utah

Little Man Claim, Wyoming

Los Ochos, Gunnison Mining Co., Colo.

Lucky Mc, Wyoming

Mallinckrodt-African Metals Residue

Marysvale, Utah

Mesa Top, New Yexico

Midnight Mines, Washington

Mineral Joe Ores, Colorado

Monticel1o Blends, Utah

Monument Valley, Arizona

Moonlight Claim, Utah

Mount Isa District, Australia

Ottawa Athabasca, Canada

Phillips Petroleum Co. (Sec. 28), New Hex.

Poison Canyon, New Mexico

Pryor Mountain, Wyoming

Riverton Ore Samples, Wyoming

Refinery Slags, Mallinckrodt and Fernald

Saint Anthony Uranium Corp., New Mexico

Schwartzwalder, Ralston Creek, Colorado

Todilto Limestone, New Kexico

U \& I Almar, Utah

Uranium Reduction Co., Utah

Utex, Utah

Vanura Group (Four Corners), Utah

Vitro, Wyoming

Western Gold and Uranium Co., Arizona

White Canyon, Utah

Whites' Rum Jungle, Australia

Woodruw Ore, New Mexico
Beport No, WIN-

$56,60,64,67,72,76$, $84,107,108,109,110$

18
58

6,12

59

54,81

58

$60,67,72,76,84$

92

5,14

40,51

$41,44,65,79,80,97$

$79,80,97$

69

66

32

$84,108,109$

68

107

$30,74,78$

$20,39,45,73,77,112$

33

11,38

36

23,25

44,65

22

47,77

42,49

50

70,106

87

110

41

97

98

96

$57,77,112$

66

$2,11,29,39,82$

51
80

35,69
Monthly Progress Reports $1 /$

$2-9,11,12 / 56,1-2-3-10-11-12 / 57,1-5 / 58$

$12 / 54,1-2-3-4-5-7 / 55$

$11-12 / 55$

$7 / 56$

$7-8 / 54$

$5-6 / 56$

$9-10-11-12 / 54,2 / 55$

$12 / 56$

$12 / 54$

$12 / 56,1 / 57$

$2 / 54,1,2,4-12 / 55,1-11 / 56,1-11 / 57$

$8 / 54$

$2-3 / 57$

$3-4-6-7-8-10 / 56,1-2-3-4-12 / 57$

$7-8-9-10-11-12 / 54,2-3-4-5-6-8 / 55,5 / 57$

$9-10-11-12 / 54$

$11-12 / 55,1 / 56$

$12 / 55,1 / 56,1-2-5-6 / 57$

$7-8-11 / 56,6 / 57$

$3-6-7 / 57$

$7 / 54,9-10-11-12 / 56,1 / 57$

$12 / 55,1 / 56$

$3-4-5-6-7-8-9 / 55$

$11 / 57,1-2-3-4-5 / 58$

$1-2-3 / 57$

$2 / 58$

7-8-9-10/54

$7-8 / 55,9-10-11-12 / 56,2 / 57$

$2-4-7-8 / 57$

$7-9-10-11-12 / 56,3-4-5-6-7-9-10-12 / 57$

$7-8-9 / 54$

$2,3,4,6-11 / 55,9-12 / 56,1-7-8-12 / 57,1 / 58$

$1-2-3 / 55$

$12 / 54,1-3-5 / 55$

$3-5-6 / 55$

$2-3-4-5-6-7 / 55,3 / 58$

$12 / 55,1-3-4-5 / 56,6 / 58$

$11 / 54,1-2 / 55$

$3-4-5-6 / 55$

2-3-4-7-8-9/56, 1-2-10/57

$6-7-10-11-12 / 55,1-2-3 / 56$

$7-9-10 / 55,2-3 / 56$

$7-8-9 / 56,8 / 57,1-2 / 58$

$12 / 55,1-2 / 56$

$11-12 / 56,1 / 57$

3-4-5-6-10-11-12/55

$7 / 54,8 / 54$

$11-12 / 56,4-5-6 / 58$

8-9-10/56

$4 / 56$

$9-10 / 55,3 / 56,6 / 57,1-2 / 58$

$3-4-5-6-7-8-9 / 57,1-4 / 58$

$7-8-9 / 57$

$6-7-9-10-11-12 / 55,9-10 / 56,2-3 / 58$

$1-3 / 55,3-4-5-6-7-12 / 56,1 / 57$

$12 / 55,1-2-3 / 56$

9-10-11/57

$8 / 54,3-8-9-11 / 55,5 / 56$

$11-12 / 55$

$7 / 57,2 / 58$

$10-11-12 / 54$

$10-11-12 / 55,2-3 / 56,6 / 58$

$5-7 / 56$

$7 / 55$

1; 2, 3, 4/56 refers to February, March, and April Monthly Progress Reports, 1956 , etc. 
Table 3

Contents of Yonthly Progress Reports Classified by Subject Symbols

July 1, 1954 - June 30, 1959

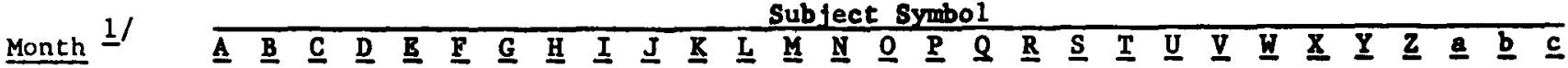

$7 / 54$

$8 / 54$

$9 / 54$

$10 / 54$

$11 / 54$

$12 / 54$

$1 / 55$

$2 / 55$

$3 / 55$

$4 / 55$

$5 / 55$

$6 / 55$

$7 / 55$

$8 / 55$

$9 / 55$

$10 / 55$

$11 / 55$

$12 / 55$

$1 / 56$

$2 / 56$

$3 / 56$

$4 / 56$

$5 / 56$

$6 / 56$

$7 / 56$

$8 / 56$

$9 / 56$

$10 / 56$

$11 / 56$

$12 / 56$

$1 / 57$

$2 / 57$

$3 / 57$

$4 / 57$

$5 / 57$

$6 / 57$

$7 / 57$

$8 / 57$

$9 / 57$

$10 / 57$

$11 / 57$

$12 / 57$

$1 / 58$

$2 / 58$

$3 / 58$

$4 / 58$

$5 / 58$

$6 / 58$

$7 / 58$

$8 / 58$

$9 / 58$

$10 / 58$

$11 / 58$

$12 / 58$

$1 / 59$

$2 / 59$

$3 / 59$

$4 / 59$

$5 / 59$

$6 / 59$

$7 / 59$

$8 / 59$

I/ $7 / 54$ refers to progress report for the period of June 16, 1954 - July 15, 1954, etc.

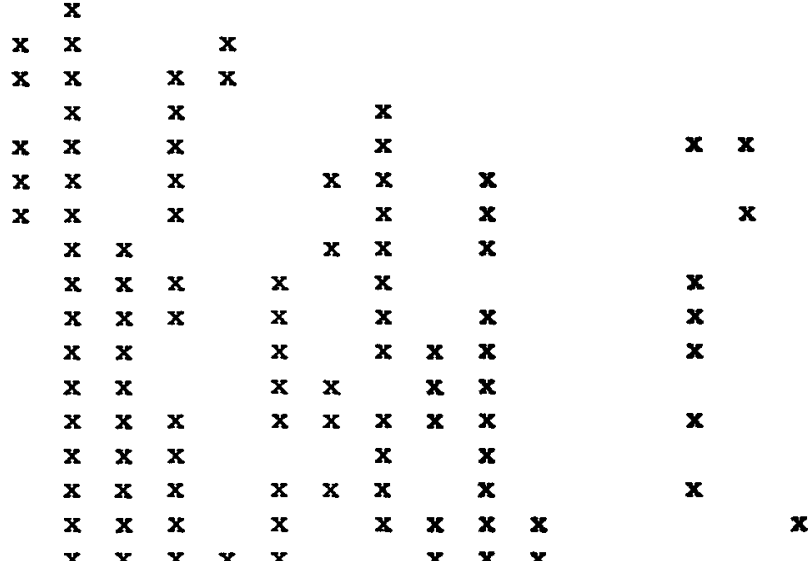

$\mathbf{x}$ 


\author{
NATIONAI IEAD COMPANY, INC. \\ Raw Materials Development Iaboratory
}

ABSTRACTS OF REPORTS

WIN-1

HARMONY ORE. J. T. Lynch. October 13, 1954. 14 p.

A sample of ore from the Harmony Mines, Union of South Africa, assaying $0.042 \% \mathrm{U}_{3} 08$ was studied to compare leaching methods and to make a preliminary study of resin poisoning. Extraction of $89.7 \%$ of the uranium was obtained by two stage cyclic leaching with 28 pounds of $\mathrm{H}_{2} \mathrm{SO}_{4}$ and 9 pounds of $85 \% \mathrm{MnO}_{2}$ per ton of ore. Best extraction of the uranium obtained by single stage leaching was $84.8 \%$ with reagent requirements of 33 pounds of $\mathrm{H}_{2} \mathrm{SO}_{4}$ and 9 pounds of $85 \% \mathrm{MnO}_{2}$ per ton of ore. After 13 loadings on IRA-400 resin using pregnant solution obtained from two stage cyclic leaching, only a trace of cobalt was found on the resin.

WIN-2

FIOTATION AND IEACHING OF PRODUCTS FROM HIGH ITIE UTEX ORES. D. R. George and R. A. Eisenhauer. December 31, 1954. 29 p.

Test data are presented on the flotation of calcite from high lime Utex ores and on leaching of the products with sulfuric acid or sodium carbonate solutions.

\title{
WIN-3
}

ACID AND CARBONATE IEACHING OF NORTH JACKPIIE ORE. J. Q. Jones, J. B. Larson, J. T. Lynch, E. S. Porter, G. Trueman and H. I. VíkIund. February 21, $1955.21 \mathrm{p}$.

Laboratory investigation of a composited drill core sample from the North Jackpile ore body near Grants, New Mexico, revealed that the ore is readily amenable to acid leaching and ion exchange. Good settling rates were obtained on neutral and acid leached pulps. An oxidant was beneficial to leaching. Carbonate leaching was also effective elther with a chemical oxidant or following a preliminary roast. Filtration of carbonate leached pulps was difficult. 
WIN -4

ION FXCHANCB RRSIN Tisting. F. Plckwick, Jr. November, 1954. $32 \mathrm{p}$.

This report deals with the testing of reain manufactured by the Bohm \& Haas Company. Data obtained in test work performed between February 1952 and November 1954 are presented.

WIN-5

RRSIN-IN-PULP PILOT PIANT TESTING OF EDCEMONT ORE. R. Hollis, C. K. MoArthur, T. F. Izzo, A. W. Griffith and R. I. Shimmin." January 11, 1955. $23 \mathrm{p}$.

Ore fram the Bdgemont District of South Dakota was treated in the Resin-In-Pulp P1lot Plant. Satlsfactory leachIng was accomplished with about 40 pounds of sulfurio add per ton of ore. Leach contact times of 10,8 , and 6 hours all yielded extractions of $97 \%$ of the urantum. No difficulty was encountered in lon-exahanging this liquor. Recovery in the adsorption units was over 99\%. A solution $0.9 \mathrm{M} \mathrm{NO} 3$ with the $\mathrm{pH}$ adjusted to 1.2 with sulfurlo acid was employed as the eluant. Pregnant eluate was precipitated with Mgo resulting in a product that averaged $67.40 \% 0_{308}$. Calculated recovery was $95.7 \%$ :

WIA-6

CARBONATS IFACHING, ACID IRACHING, SETTLING, AND ION FXCHANCE IRSTING OF CAL-URANIth ORE: D. R. Ceorge; J. B. Larson, B. S. Porter, and H. I. Viklund. October 3, 1955. 37 p.

The reaults of acld and carbonate leaching tests, ion exchange tests of acld leach solutions, thickening tests of acid leached pulps, cyclic carbonate leaching testa, and filtration tests of carbonate leached pulps are desoribed.

WIH-7

THR SPECTROPHOTOMETRIC DETBPUMNATION OF PHOSPHORUS AS MOLYBDOVANADOPHOSPHORIC ACTD. K. P. Quinlan and M. A. DeSesa. February 21, 1955: $21 \mathrm{p}$.

The molybdovanadophosphorlc acid method for the apectrophotometric determination of phosphorus has been extensively re- 
WIN-7 (Continued)

Vlewed. The optimum concentrations of acid, vanadium (V), and molybdenum (VI) were determined by factorlal experiment. The optimum color development occurs in solutions which are $0.4 \mathrm{M}$ in acid, 0.02 to $0.06 \mathrm{M}$ molybdenum (VI) and 1.0 to $4.0 \mathrm{mM}$ vanadium (V). The opt1mum range is 3 to $20 \mathrm{ppm} \mathrm{P}_{2} \mathrm{O}_{5}$ for 1 on cells. Dichromate 1s the only serlow interference, but can be eliminated by volatilization of the chromium as chromyl chloride.

\section{WIT-8}

PERLIMINARY IRACHING AND ION EXCHANGE STUDIRS OF A SAMPLE OF WESTERN GOLD AND URANIUM COMPANY ORE. J. T. Lynch and H. I. Viklund. July 16, 1956. 16 p.

A sample of ore from Western Gold and Uranium Company properties in Arlzona, assaying 0.217 per cent $\mathrm{U}_{3} \mathrm{OB}$, was studied to determine leaching and lon exchange data. Acld requirements employling various leaching procedures and uranium fon exchange loading using different manufacturer's resin are presented. Same data are also presented on carbonate leaching.

\section{WIX-9}

MSGRLLANROUS ELUTION STUDIES. A. R. Kazanjian. March 5, 1956. $27 \mathrm{p}$.

An Investigation was made of the variables involved in a $5 \mathrm{M} \mathrm{NaCl}-\mathrm{H}_{2} \mathrm{O}$ elution scheme. The most promising procedure was used In a cyclic lon exchange system. Studieg were also made on the effect of Iron to phosphate ratios on uranium Ion exchange and the effect of temperature on elution.

WIM-10

THE SPBCTROPHOTCMETRIC DEWBMINATION OF TETRATHIONAZR. 0. A. Nietzel and M. A. DeSesa. April 18, 1955. 18 p.

The spectrophotometric method of Robinson for the determination of tetrathionate has been modifled to yleld a procedure of greater senoltivity and accuracy. The procedure depends on conversion of tetrathionate to thiocyanate and determination of the thiocyenate formed with an excess of ferric lron. By developIng the color in opaque cylinders, the rapid decomposition of the 


\section{WIN-10 (Continued)}

ferrlo thlooyanate oolor has been eliminated for all practloal purposes. The use of ferric nitrate and nitric acid instead of ferrto chloride and hydrochlorlo acld has decreased the optloal density of the reagent blaniss. The optimum cancentrations of reagents have been eveluated. By measuring the finel oolor at 460 mu Instead of at $525 \mathrm{m \mu}$ a two fold Inorease in oensitivity has boen sohleved. A rapld, acourate prosedure is presented for analyzing 'Ilquore contalning as little as 0.002 gram of tetrathionate per 11 ter.

WIN-11

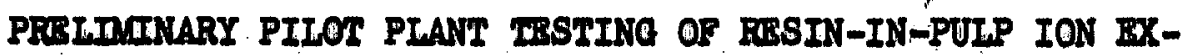

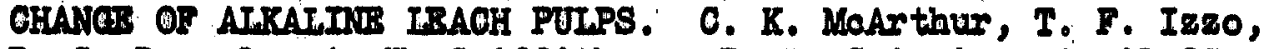
R. A. Beverly, A. W. Oriffith and R. L. Shimmin. April 25, 1955. $21 \mathrm{p}$.

To determine the posalbility of recovering uranium erom alkaline leach pulpa; Utex ore from Stookplie 33 at Montioello, Vteh was treated in the Resin-In-Pulp P1lot Plant olroults. From the test wark a tentative alkeline Resin-in-Pulp P1lot Plant $110 \pi-$ oheet was establiched. Data are presented on the recovery by adsorption unite as rell as information on the elution and preolpitathon of uranium concentrate.

VIN-12

EISIM-IN-PUIP PILOT PIANT TRSTINO OF CAL-URANIUM ORS. Q. I. MaArthur, A. W. Ertef1th, T. F. Izzo, R. O. Beverly and R. I. Shimoin. April 29, 1955. $19 \mathrm{p}$.

Cal-Orantum ore from the Ifabon Velley Dlatrlot of Utah was treated in the Reain-In-Pulp Pliot Plant from November 21 to December 19; 1954. The averago grade of the ore as troated was

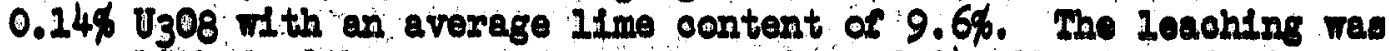

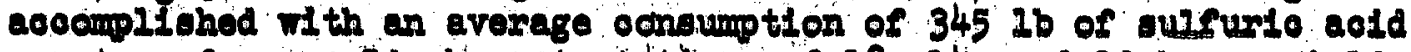
pex ton of ore. Heon contaot timo of 18,14 , and 10 houre ylelded leach extractione of $95.5,92.9$, and $92.8 \%$, respeotivaly. One 10ach of 10 houre contiot time with the addition of 5 lb Mag par ton of ore resulted In an extraotion of 94.8\%. Some diffloulty rao

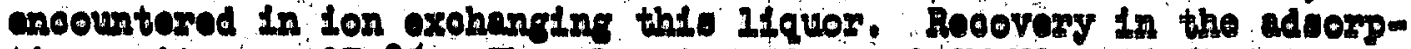
then unite ras $97.8 \%$. The oluant used ras $0.9 \mathrm{MNO}$.

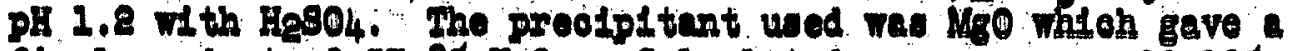
Alnal. produst of $57.8 \%$ U308. Oaloulated reoovony vas $90.13 \%$. 
WIN-13

URANIUM RRCOVRRY BY HYDROCEN PEDUCTION OF CARBONATE IEACH IIQUORS. H. Papazian. November 1, 1955. $25 \mathrm{p}$.

The application of hydrogen reduction in the presence of a nickel catalyst for the recovery of uranium from carbonate liquors has been investigated. Tests were conducted on a laboratory seale in batch and continuous operations.

WIN-14

IABORATORY INVESTIGATION OF EDGRMONT SANDSTONB ORE. G. Truemen, H. I. Viklund, J. B. Larson and P. N. Thomas April 18, 1955. $33 \mathrm{p}$.

Laboratory investigations were made of a sample of sandstone-type uranium ore from Idgemont, South Dakota. The amenability of the ore to acid and carbonate leaching was studied as rell as methods of recovering the uranium from leach solutions.

WIN-15

ION HXCHANCR RESIN TESTING - PART II PERMUTIT RESIMS TESTED DURING THE PRRIOD FEBRUARY 1952 THROUGH NOVEMBRR 1954.

F. Pickwick, Jr. November 15, 1955. $30 \mathrm{p}$.

This report presents the results of test work performed on samples of Ion exchange resins submitted by The Permutit Company to this laboratory for evaluation in the perlod February 1952 through November 1954. During this period, the uranium adsorption and elution properties of the Permutit resins have been observed to improve considerably. By using early test data, The Permutit Company was able to adjust the manufacture of their resins so that later resin lots showed improved uranium adsorption and elution properties.

WIN-16

PRECIPITATION OF URANIUM AND VANADIUM FROM GARBONATE IRACH IIQUORS USIMG SODIUM AMALAAM. H. E. Dixon. September 20, 1955. $32 \mathrm{p}$.

Basic equipment design, resulta of laboratory test work, and a partial economic analysis of the sodium-amalgam precipitation and reduction process as applied to carbonate leach solutions are presented. 
WIN-I7

INITIAL OPERATION OF NEW ACID LEACH RESIN-IN-PUIP PILOT PIANT. C. K. McArthur, T. F. Izzo and R. L. Shimin. July 5, 1955. 28 p.

The components and operation of the new acid leach Resin-inPulp (RIP) Pilot Plant and the results of a shakedown run are described. The new fourteen bank system proved to be practical in operation and highly efficient for uranium recovery from desanded ore pulps.

WIN -18

RESIN-IN-PULP PILOT PIANT TESTING OF ARROWHEAD ORE. C. K. MCArthur, T. F. Izzo, and R. I. Shimmin。 May 23, 1955. 30 p.

Arrowhead ore from the Cameron district of Arizona was successfully treated in the Resin-In-Pulp Pilot Plant. Leach extraction with the use of 205 pounds of $\mathrm{H}_{2} \mathrm{SO}_{4}$ and 10 pounds of $\mathrm{MnO}_{2}$ per ton of feed averaged 95.74 per cent. Ion exchange recovery averaged 99 per cent of the uranium in solution with nine banks of resin on exhaustion. The eluting solution used for the majority of the test period was $0.9 \mathrm{M} \mathrm{NH}_{4} \mathrm{NO}_{3}$ adjusted with $\mathrm{H}_{2} \mathrm{SO}_{4}$ to a pH of 1.2. The product from nitrate elution averaged 75.7 per cent $\mathrm{U}_{3} \mathrm{O}_{8}$..

WIN-19

DESCRIPTION OF AIKALINE IEACH PILOT PIANT AT GRAND JUNCTION; COLORADO J. Q. Jones, D. 0. Skiles, and G. Winslow. June $24,1955.13$ p.

The pilot plant facilities at Grand Junction, Colorado, for testing the amenability of domestic uranium ores to the carbonate leaching process are described. The chemistry of uranium dissolution in carbonate solutions and its precipitation with $\mathrm{NaOH}$ is discussed briefly.

WIN-20

INITIAL TESTS OF IASAI SHAFT ORE IN THE ALKAIINE IEACH PILOT PIANT. J. Q. Jones, D. O. Skiles, and G. Winslow. July 29, 1955. 26 p.

Initial testing of LaSal ore in the Alkaline Leach Pilot Plant at Crand Junction, Colorado, took place during the period February 15 to March 7, 1955. By the use of an extended leaching time of 112 .hours and a temperature of $172^{\circ} \mathrm{F}$, a dissolution of 99.1 per cent of the uranium was obtained. Three-stage filtration of the pulp gave a soluble loss of 1.5 per cent and a filter rate of 276 pounds per square foot per 24 hours, using 0.05 pound of Separan-2610 per ton. The best filter rate obtained was in excess of 600 " pounds per square foot per 24 hours. Overall recovery of uranium in the "yellow cake" was 95.7 per cent for the entire run. The product assayed 75.5 per cent on a dry basis, and slightly better than 80 per cent $\mathrm{U}_{3} \mathrm{O}_{8}$ if washed on the filter before drying. Indicated reagent consumptions are 20 pounds of caustic soda and 0.1 pound of Separan per ton of ore. Fuel oil requirements for pulp heating were 21.3 gallons per ton of ore. 
WIN-2I

\section{ELECTROLYTIC STUDIES IN CARBONATE SOLUTIONS. A. R. Kazanjian.} April 4, 1956. 23 p.

The electrolytic reduction and precipitation of uranium from carbonate leach solutions was investigated. Electrolytic reduction of uranium in a mercury cathode cell followed by precipitation with sodium hydroxide was also studied.

WIN-22

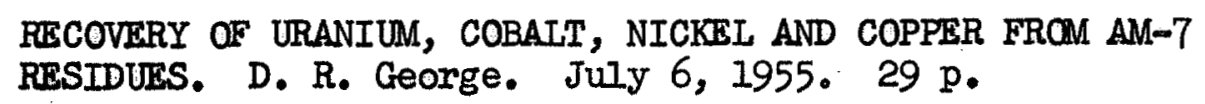

The results of laboratory investigations for the recovery of uranium, cobalt, nickel, and copper are presented. The test work includes sodium carbonate leaching, sulfuric acid leaching, ion exchange testing, and cobalt, niokel, and copper precipitation studies.

WIN-23

RESIN-IN-PULP PILOT PIANT TESTING OF LOS OCHOS ORE. C. K. McArthur, A. W. Griffith, R. W. Shimmin. October 15, 1955. $30 \mathrm{p}$.

During the months of April through June of 1955, Ios Ochos ore from the Gunnison area of Colorado was treated in the Acid Leach Resin-In-Pulp Pilot Plant at Grand Junction, Colorado. The report presents detailed information on leaching, ion exchange; and precipitation in connection with the processing of this ore. Results showed that the ore is very amenable to the process and that relatively low acid consumption was required for good uranium extraction.

WIN -24

THE RECOVERY OF URANIUM FROM SUIFATE IEACH LIQUORS BY THE TBP-THIOCYANATE PROCESS. Ho G. Petrow and.H.N. Marenburg. November $7,1955.17 \mathrm{p}$.

A process for the solvent extraction of uranium from clear sulfate leach liquors has been developed. The uranium is extracted into a tributyl phosphate-kerosene solvent as uranyl thiocyanate. The extracted uranyl thiocyanate is re-extracted into aqueous sodium carbonate. Iaboratory data indicate the process to be economically applicable to plateau ores. 
WIN-25

IABORATORY INVESTICATION OF THORNBURG LOS OCHOS ORE. E. S. Porter, P. N. Thomas, H. I. Viklund and G. Trueman. October 17, 1955. $31 \mathrm{p}$.

Laboratory investigations were made of three samples of uranium ore from the Ios Ochos lease of the Thornburg Mining Company. The amenability of the ore to acid and carbonate leaching was studied as well as methods of recovering the uranium from acid leach solutions.

WIN-26

THE RECOVERY OF URANIUM FROM ORE PULPS USING FIXED ION EXCHANGE RESIN BEDS. G. W. Clevenger and J. T. Iynch. December 2I, 1955. $25 \mathrm{p}$.

The development of new techniques which enable an ore pulp to pass through fixed ion exchange resin beds for the recovery of dissolved values is described. Data are given for the recovery of uranium from various ore pulps in an 11-inch diameter pilot plant column.

\section{WIN -27}

DEVELOPMENT OF AN EFFICIENT ELUANT FOR REMOVAL OF MOLYBDENUM FROM ANION EXCHANGE RESINS. K. P. Quinlan and R. J. Barmy. August 1, 1956. 21 p.

The poisoning of anion exchange resins by molybdenum adsorption has been briefly studied. Although no satisfactory method was found to prevent the adsorption of molybdenum from pregnant leach liquors, an effective eluant for molybdenum was developed which is superior to the 5-10\% sodium hydroxide solutions previously used for this puxpose. It was found that the presence of small quantities of a good displacing ion such as chloride or nitrate in dilute solutions of sodium or ammonium hydroxide greatly increases the speed and efficiency of molybdenum removal. Investigations also revealed that by the addition of 0.5 per cent sodium or ammonium hydroxide, RIP barren eluate bleed can be used effectively as an eluant for molybdenum.

WIN-28

SQLVINT EXTRACTION OF URANIUM FRCM SULFURIC ACTD ELUATES. H. G. Petrow, K. P. Quinlan, H. N. Marenburg and J. Apidianakds. March 29, 1956. 16 p.

A process for the elution of uranium from loaded Amberlite XE-123 resin with sulfuric acid, and the subsequent recovery of the uranium from the pregnant eluate by solvent extraction has been devised. The process eliminates many of the difficulties accompanying both nitrate and chloride elution, and in an RIP system, indicates a lower chemical cost than with either nitrate or chloride elution. 
WIN-29

STUDIES OF THE EFFECTS OF VARIOUS TYPES OF AGITATION ON THE EXTRACTION OF URANIUM FROM A SAMPLS OF UTEX OFE. P. N. Thomas. December 1, 1955. $41 \mathrm{p}$.

Test data are presented showing the effects of various types of agitation on the extraction of uranium by acid leaching Utex Sample 75-7.

WIN -30

RECOVERY OF URANIUM FROM ILAKEVIEW IEACH IIQUOR USING TRIIAURYIAMINE. 0. A. Nietze1, C. F. Lubinger and J. Apidianakis. September 11, 1957. 14 p.

An economical recovery of uranium from Lakeview leach liquor was obtained with a solvent extraction technique using trilaurylamine as the uranium extractant.

WIN-31

A SOLVENT IBACHING PROCESS FOR THE PRODUCTION OF HIGH-PURITY URANIUM PRODUCTS DIRECTLY FROM LOW-GRADE ORES. P. Galvanek, Jr. and M. S. Pelland. December 9, 1955. 22 p.

A solvent leaching process is described in which an organic solvent, consisting of 5 volume per cent tributyl phosphate and 95 volume per cent kerosene, is used to selectively leach uranium directly from nitrate-conditioned, acid-cured, low-grade ores. Filtration and other clarification operations common to most ore treatment processes are eliminated. The process has been tested on several Colorado Plateau ores, both primary and secondary, yielding overall uranium recoveries ranging from 92 to 98 per cent. A uranium product analyzing over 99 per cent $\mathrm{U}_{3} \mathrm{O}_{8}$ is produced.

WIN-32

RESIN-IN-PULP PILOT PLANT TESTING OF HIDDEN SPLENDOR ORES. D. O. Skiles and R. I. Shimmin. January 20, 1956. 50 p.

During the period June 18, 1955 through September 8, 1955, ore from the Delta Mine of the Hidden Splendor Mining Company was treated in the Acid Leach Resin-In-Pulp Pilot Plant at Grand Junction, Colorado. The report presents detailed information on the leaching, ion exchange, and precipitation involved in processing this ore. Results show the ore to be amenable to the Resin-In-Pulp extraction process. 
WIN-33

IABORATORY INVESTIGATIONS OF IEHIGH COAL AND NAVIGATION COMPANY ORE. G. Trueman; E. S. Porter and A. R. Kazanjlan. March 8, 1956. $19 \mathrm{p}$.

The results of laboratory tests on a sample of ore from the Iéhigh Coal and Navigation Company stockpile at Palmerton, Pennsylvania are described. The test work included acid leaching, filtration and thickening, and recovery of uranium from acid leach solutions by ion exchange.

WIN -34

THE FLUORTMETRIC DETERMINATION OF URANIUM. F. A. Centanni, A. M. Ross and M. A. DeSesa. February 10, 1956. 40 p.

A method evolved from over ten years experience is described for the fluorimetric determination of uranium. This method is especially applicable for laboratories which are planning to install equipment for fluorimetric analysis since the fluorimeter employed is available commercially and the procedure is described in detail. Also reported is a new fluoride flux which is superior in sensitivity, precision, and ease of use to previously employed fluxes.

WIN -35

RESIN-IN-PULP PILOT PLANT TESTING OF WHITE CANYON ORES. J. Q. Jones, W. A. Millsap, T. F. Izzo and R. I. Shimmin. February 13, 1956. 45 p.

During the period of September 15 to November 14, 1955, White Canyon ore from Stockpiles 19 and 35 at Monticello, Utah, was treated in the Acid Leach Resin-In-Pulp Pilot Plant at Grand Junction, Colorado." The ore contained in these stockpiles originally came from the White Canyon area of Utah. The report contains detailed information on grinding, leaching, sand-slime separation, ion exchange, and precipitation in connection with the processing of this ore. Results show the ore to be amenable to the Resin-In-Pulp process.

WIN -36

IABORATORY TESTING OF IITTIE MAN CIAIM ORE. G. Trueman. February 23, 1956. $17 \mathrm{p}$.

Laboratory studies were made of a sample of ore from the Little Man Claim in Wyoming. The amenability of the ore to acid leaching and ion exchange was investigated as well as the possibility of molybdenum removal by flotation. 
WIN-37

SEMI-PILOT OPERATION OF THE AMMONIUM CARBONATE LEACHING

PROCESS. E. T. Hollis. February 27, 1956. $29 \mathrm{p}$.

A process utilizing ammonium carbonate as a lixiviant for uranium and steam stripping as a means of recovery of the values has been tested. Some data are given on both leaching and precipltation aspects of the flowsheet.

WIN-38

AMENABIIITY TESTING OF HOMESTAKE LITTLE BEAVER AND RICHARDSON CLATM ORES. G. Trueman, E. S. Porter, H. I. Viklund and J. B. Larson. September 10, 1956. 31 p.

The results of the laboratory investigation of ore samples from the Iittle Beaver claim and from the Richardson claim are discussed. Data are presented on carbonate leaching, acid leaching, settling and filtration, and ion exchange of acid liquors.

WIN-39

ALKALINE RESIN-IN-PULP PROGESS FOR THE HECOVERY OF URANIUM FROM ITS QRES. J. Q. Jones, J. G. Roeschlaub, R。 I. Shimmin, H. F. Wilson, and H. D. Moulton, Jr. January 19, 1956. 71 p.

During the period May 25, 1955 through August 23, 1955, process development studies were carried out in the Alkaline Leach-RIP Pilot Plant at Grand Junction, Colorado. Ia Sal ore was used during this time. From September 2, 1955 to November 12, 1955, a special blended sample of Utex ore from the Uranium Reduction Company was treated to determine process amenability for vanadium bearing ores of the type found in the BIg Indian Wash district of Utah. The report presents detalled information on the process and its development and on the leaching, ion-exchange, and precipitation Involved in the processing of these ores. Results show the process can be applied commercially to the treatment of some uranium ores.

WIN -40

RESIN-IN-PULP PILOT PIANT TESTING OF FOUR CORNERS URANIUM COMPANY ORES. H. F. Wilson, J. Q. Jones and R. L. Shimmin. April 18, 1956. $34 \mathrm{p}$.

Ores produced by the Four Comers Uranium Company from the Green River District in Utah were treated in the Acid Ieach Resin-In-Pulp Pilot Plant at Grand Junction, Colorado during the period from November 14 through December 16, 1955. The report presents detailed information on the leaching, ion exchange, and preclpitation involved in processing these ores. Results show the ores to be amenable to the Acid Leach Resin-In-Pulp recovery process. 
WIN -41

IABORATORY INVESTIGATION OF PRYOR MOUNTAIN ORE. H. I. VikIund and H. Papazian. September 12, 1956. $18 \mathrm{p}$.

The results of the laboratory investigation of an ore sample from the Pryor Mountain Area of Montana and Wyoming are presented. Alkaline and acid leaching are discussed and methods are recommended for pilot scale testing.

WIN-42

ACID IEACH RESIN-IN-PULP PILOT PLANT TESTING OF SPOKANE MTDNIGHT ORE. J. Q. Jones; R. G. Beverly and R. L. Shimmin. April 20, 1956. 43 p.

Uranium ore from the Midnight Mines near Spokane, Washington was treated in the Acid Leach Resin-In-Pulp Pilot Plant at Grand Junction, Colorado during the period of December 18, 1955, through January 25, 1956. The report presents detailed information on leaching, ion exchange, and precipitation involved with the processing of the Spokane Midnight ore. Also included are sections on mill design considerations and the results of colum ion exchange tests performed at the Winchester Raw Materials Development Laboratory. From the pilot plant test, it was concluded that the ore is amenable to the Acid Ieach Resin-In-Pulp Process. Laboratory test work showed the leach liquor exhibited excellent column ion exchange properties.

WIN -43

THE DIRECT SPECTROPHOTOMETRIC DETERMINATION OF URANIUM IN SULFATE AND CARBONATE SOLUTIONS. B. W. Wessling and M. A. DeSesa. June 18, 1956. 12 p.

A spectrophotometric method of analysis for uranium based on the absorption of ultraviolet light by uranyl sulfate and carbonate complexes is described. The method has been used to provide accurate, rapid analyses of uraniferous solutions used in batch and column ion exchange loading tests:

$\mathrm{WIN}-44$

ACID IBACH CCD - COLUMNS PILOT PIANT TESTING OF IUCKY MC ORE. T. F. Izzo, J. Q. Jones and R. L. Shimin. May 12, 1956. 64 p.

From January 24 to April 10, 1956, Lucky Mc ore from the Riverton area of Wyoming was treated in the Acid Leach CCD-Colums Pilot Plant at Grand Junction, Colorado. The report contains detailed information on the grinding, leaching, liquid-solid separation by continuous countercurrent decantation, ion exchange, and precipitation in connection with the processing of this ore. A section is included on mill design considerations. Results show the ore to be amenable to the CCD-Columns recovery process. 
WIN -45

FINAI REPORT OF THE AIKAIINE IEACH - FIIIRATION PILOT PIANT IESTING OF IaSAL ORE. A. W. Griffith; T. F. Izzo, D. O. Skiles and G. Winslow. April 5, 1956. 64 p.

Iasal ore from the Big Indian Wash district of Utah was treated for a second time in the Alkaline Leach - Filtration Pilot Plant at Grand Junction because of a suspected change in ore characteristics as mining progressed. The report contains detailed information on grinding, thickening, leaching, residue filtration, and precipitation. A section on mill design considerations is also included. Results show the ore to be amenable to the Alkaline Leach - Filtration Process.

\section{WIN -46}

SPECTROPHOTOMETRIC DETERMINATION OF URANIUM WITH THIOCYANATE IN BUTYL CELIOSOLVE-METHYL ISOBUTYL KETONB-WATER MEDIUM. 0. A. Nietzel and M. A. DeSesa. September 6, 1956. 20 p.

A spectrophotometric method for the determination of uranium in ores and leach liquors is presented. This method consists of a separation of uranium from interfering ions by extraction into methyl isobutyl ketone, using aluminum nitrate as a salting agent, followed by development of the color on a portion of the extract with a solution of ammonium thiocyanate in a butyl cellosolve-water solvent. The yellow uranyl thiocyanate complex forms immediately, and the color is stable for at least 48 hours. The optimum range of uranium concentration at $375 \mathrm{m \mu}$ is from 0.2 to 2.0 grams $\mathrm{U}_{3} \mathrm{O}_{8}$ per liter in the sample aliquot. The coefficient of variation of absorbance measurements on standard solutions at $375 \mathrm{m \mu}$ was found to be \pm 0.34 per cent. Titanium is the only serious interference but procedures are given which make it possible to analyze samples containing as much as $5 \mathrm{mg}$ of titanium in the sample aliquot.

\section{WIN -47}

ACID IKACH RESIN-IN-PULP PILOT PIANT TESTING OF MESA TOP ORE. J. Q. Jones, P. N. Thomas and R. I. Shimmin. May 25, 1956. $38 \mathrm{p}$.

Mesa Top ore from the Ambrosia Lake district of New Mexico was treated in the Acid Ieach Resin-In-Pulp Pilot Plant at Grand Junction, Colorado, from February 27 to April 6, 1956. This report contains data on the leaching, ion exchange, and precipitation characteristics of that ore. A section on mill design considerations is Included. The data show that Mesa Top ore is amenable to the Acid Ieach Resin-In-Pulp Process if molybdenum is removed from the resin periodically. 
WIN -48

PRECIPITATION OF MOLYBDENTM FROM ION EXCHANGE FEEDS BY NEUTRALIZATION IN THE PRESENCE OF IRON. P. J. Magno. November $15,1956.38 \mathrm{p}$.

The removel of molybdenum from acid leach liquors by neutralization in the presence of iron has been evaluated as a method of decreasing the concentration of molybdenum to a tolerable level in ion exchange feeds. Such variables as acid concentration, Iron to molybdenum ratio, temperature, and concentration of silicate and aluminum in the leach liquor were examined in order to develop the optimun conditions for the precipitation of molybdenum. The precipitation procedure was tested on leach liquors from Ambrosia Lake District Ore and from several lignite ores. Leaching tests made on lignite ores indicate that iron and molybdenum can be precipitated during the leaching by suitable control of the acidity.

$W I N-49$

IABORATORY INVESTIGATION OF MIDNIGHT MINES ORE: E. S. Porter, E. T. Hollis and H. I. Viklund. December 14, 1956. 24 p.

Laboratary amenability testing was carried out on two samples of are from the Midnight Mines, Spokane, Washington. Acid leaching, filtration and thickening of neutral and acid pulps, Ion exchange of acid liquors, and carbonate leaching are discussed. Results of ion exchange testing of an acid leach liquor from the Grand Junction Pilot Plant are also reported.

WIN -50

IABORATORY INVESTIGATION OF MINERAL JOF ORE. E. S. Porter and H. I. Viklund. January 28, 1957. 26 p.

The results of laboratory testing of two samples of ore from the Mineral Joe Mine in the Jo Dandy Area are presented. A major pert of the discussion concerns acid leaching, solid-liquid separation of acid leached pulps and ion exchange of the resulting solutions. Data are also presented on the uranium extraction and reagent consumption by leaching with carbonate solutions. The results of one test on the recovery of vanadium after extracting the uranium are reported. 
WIN-51

FOUR CORNERS URANIUM COMPANY ORE. J. B. Breymann, T. J. Sentementes, H. I. Viklund and J. B. Larson. February 1958. 20 p.

Laboratory amenability tests were mun on three samples recelved from Four Corners Uranium Company. The discussion includes acid and carbonate leaching, ion exchange and settling of acid leached puilps.

WIN-52

DETERMINATION OF TRIBUTYL PHOSPHATE. R. J. Allen and M. A. Desesa. November $15,1956.27 \mathrm{p}$.

Because of the need for a rapid method of analysis for TBP in kerosene and hexane diluents, an investigation into proposed methods of analysis for TBP was made. As a result of this study, the two indirect methods based on the proportional extraction of nitric acid or uranium by solutions of TBP were modified and improved. Also a new, very sensitive, indirect photometric method based on the ultreviolet absorbance of the TBP-urantum complex was developed. In conjunction with an evaluation of the acid saturation method, the successive formation constants for the TBP-nitric acid complexes were determined to be 0.45 for $\operatorname{TBP}\left(\mathrm{HNO}_{3}\right)$ and 0.039 for $\mathrm{TBP}\left(\mathrm{HNO}_{3}\right)_{2}$.

WIN -53

FEMOVAL OF MOLYBDENUM FROM ACID IBACH LIQUORS BY ACTIVATED CARBON. B. T. Hollis and H. E. DLxon. July 29, 1958. 25 p.

Data are presented on the adsorption of molybdenum on activated carbon. The effect of retention time and linear flow on adsorption, the use of sodium hydroxide as an eluant, and the possibility of recovering molybdenum from the caustic eluate are discussed.

WIN -54

IABORATORY INVESTIGATION OF DAKOTA IIGNITES. R. J. Woody, D. R. George, H. Petrow, J. B. Breymann and E. S. Porter. Apti, I, 1957. 167 p.

This report deals with the laboratory investigation into methods of recovery of uranium from Dakota Iignites. A flowsheet is recommended for pilot plant testing. 
WIN -55 .

A SPECTROPHOTOMETRIC INVESTIGATION OF VANADIUM(V) SPECIES IN ALKALINE SOLUTIONS. I. Newman, W. J. Lafleur, F. J. Brousaides and A. M. Ross. June 10, 1957. $41 \mathrm{p}$.

The interpretation of spectrophotometric data has demonstrated that both monohydrogen orthovanadate and pyrovanadate are formed during the first break in the titration of orthovanadate with acid. A constant of $0.097 \pm 0.005$ has been obtained at $25^{\circ} \mathrm{C}$ for the hydrolysis of orthovanadate to monohydrogen orthovanadate at an ionic strength of 3.0 for vanadium concentrations of $2 \times 10-4 \mathrm{M}$ to $1 \times 10-2 \mathrm{M}$, hydroxide concentrations of $0.01 \mathrm{M}$ to $3.0 \mathrm{M}$ and wavelengths of $260 \mathrm{m \mu}$ to $360 \mathrm{m \mu}$. A constant of $48 \pm 5$ has been obtained for the dimerization of monohydrogen orthovanadate to pyrovanadate for vanadium concentrations of $0.01 \mathrm{M}$ to $0.1 \mathrm{M}$ and hydroxide concentrations of $0.0015 \mathrm{M}$ to $0.01 \mathrm{M}$.

WIN -56

AMENABILITY TESTING OF AMBROSIA LAKE DISTRICT ORE. H. E. Dixon and H. I. Viklund. Jenuary 2, 1958. $62 \mathrm{p}$.

The results of acid and alkaline amenability tests on 28 samples from the Ambrosia Lake District of New Mexico are presented.

WIN -57

ALKAIINE IEACH - FILTRATION PILOT PILANT TESTING OF TODIITO

BLACK IIMESTONE ORE. A. W. Griffith, W. A. Millsap and

G. Winslow. December 19, 1956. 37 p.

During the period of February 20 to March 20, 1956, Todilto Black Iimestone ore from Stockpile 79 at Grants, New Mexico was treated in the Alkaline Leach - Filtration Pilot Plant at Grand Junction, Colorado. The ore contained in this. stockpile came from the Grants area of New Mexico. The report contains detailed information on grinding, thickening, leaching, filtration, and precipitation in connection with the processing of this ore. Results show the ore to be amenable to the Alkaline Leach - Filtration process.

WIN -58

AMENABILITY TESTING OF ORES FROM KARNES COUNTY AND ADJACENT

AREAS IN TEXAS. D. R. George and J. T. Lynch. June 23, 1958. $31 \mathrm{p}$.

The results of amenability tests on ores from Karnes, Duval, Gonzales and Atascosa Counties in Texas are presented. 
WIN -59

IABORATORY INVESTIGATION OF E. L. CORD SAMPIE. E. S. Porter and H. I. Viklund. January 14, 1957. 18 p.

The results of metallurgical tests involving acid and carbonate leaching of a sample of ore from the E. L. Cord Associates, Jen-Jackie Claim, in the Big Indian Wash area of Utah are presented.

WIN -60

ACID -IEACH - RESIN-IN-PULP PILOT PLANT TESTING OF RIO de ORO DYSART SHAFT OFE. A. W. Griffith, M. A. Peters, W. D. Charles and R. L. Shimmin. January 7, 1957. 49 p.

During the period of April 27 to June 8, 1956, Rio de Oro Dysart Shaft Ore from the Ambrosia Lake District, New Mexico, was treated in the Acid Leach - Resin-In-Pulp Pilot Plant at Grand Junction, Colorado. The report contains information on grinding, leaching, sand-slime separation, ion exchange, solvent extraction of $\mathrm{H}_{2} \mathrm{SO}_{4}$ pregnant eluates, and precipitation. Results show the ore to be amenable to the Resin-In-Pulp process.

WIN-6I

TECHNIQUES FOR THE EVALUATION OF AMINES AS URANIUM EXTRACTANTS AND PROPERTIES OF SOME SATISFACTORY AMINES. H. G. Petrow, 0. A. Nietzel, J. C. Apidianakis, R. W. Lindstrom and C. F. Lubinger. August 26, 1957. $47 \mathrm{p}$.

Techniques applicable to the evaluation of amine extractants are described. In addition, data determined for several comercial amine products are presented.

WIN-62

ION EXCHANGE - SPECTROPHOTOMETRIC DETERMINATION OF THORIUM. 0. A: Nietzel, B. Wessling and M. A. DeSesa, February 15, 1957. $16 \mathrm{p}$.

A sensitive method of analysis was needed for the determination of thorium in connection with studies in this laboratory on the production of thorium-free uranium concentrates. Two ion exchange procedures were developed for the separation of thorium prior to spectrophotometric determination with thorin reagent. In the anion exchange procedure, possible cation interferences are removed by adsorption of their chloro 
WIN-62 (continued)

complexes from 9M hydrochloric acid onto Dowex-1 resin. The more specific cation exchange method consists of adsorption of cations from the sample onto Amberlite IR-120 resin, elution of most of the cations with $2 M$ hydrochloric acid, and recovery of the thorium by elution with 3M sulfuric acid. The developed procedures were successfully used to determine thorium in a variety of samples and should find application in the determination of low concentrations of thorium in other complex materials.

WIN -63

TMPROVEMENTS IN THE FLUOROMETRIC DETERMINATION OF URANIUM. F. A. Centanni and T. J. Morrison, Jr. April 3, 1957. 22 p.

Modifications in the instrumentation and method used in the fluorometric determination of uranium are reported. The elimination of the reference source in the Galvanek-Morrison Fluorimeter has improved the operating stability of the instrument and simplified its operation. Also reported is an automatic fusion burner unit, which minimizes the atmosphere-temperature fluctuations and makes possible better reproducibility and greater accuracy in the uranium determination.

WIN-64

AMENABILITY TESTING OF ADDITIONAL SAMPIES FROM THE AMBROSIA IAAKE DISTRICT. R. U. Johnson, H. I. Viklund and E. J. Hammond. May 12, 1958. 25 p.

This report presents the results of laboratory amenability testing of five additional samples of ore from the Ambrosia Lake District in New Mexico. The test work includes acid and carbonate leaching, settling and filtration testing, and solvent extraction of actd leach liquors.

WIN -65

IABORATORY INVESTIGATION OF RIVERTON STOCKPILE ORE. E. S. Porter and H. I. Viklund. March 4, 1957. 23 p.

The results of metallurgical tests of samples of ore from stockpiles one and two at the Riverton, Wyoming ore buying station are reported. 
WIN-66

ALKALINE IEACH - FILTRATION PILOT PLANT TESTING OF U \& I ORE. A. W. Griffith, W. A. Millsap and G. Winslow. January 28, 1957. $56 \mathrm{p}$.

During the period November 8, 1955, through February 12, 1956, U \& I ore from the Hecla Mining Company's Fortunate Claim and from the Hidden Splendor Mining Company's Farwest Claim was treated in the Alkaline Leach - Filtration Pilot Plant at Grand Junction, Colorado. The report contains detailed information on grinding, leaching, filtration, and precipitation in connection with the processing of these ores. A section on mill design considerations is also included. Results show the ores to be amenable to the Alkaline Ieach - Filtration process.

WIN -67

ALKALINE IEACH - FILTRATION PILOT PIANT TESTING OF RIO de ORO DYSART SHAFT ORE. R. G. Beverly, W. A. Millsap and G. Winslow. February 15, 1957. 57 p.

During the period of May 11 to July 25, 1956, Rio de Oro Dysart Shaft Ore from the Ambrosia Lake District of New Mexico was treated in the Alkaline Leach - Filtration Pilot Plant at Grand Junction, Colorado. The report contains detailed information on grinding, leaching, filtration, and precipitation in connection with the processing of this ore. Both Pachuca and autoclave leaching were employed. Results show the ore to be amenable to the Alkaline Leach Filtration process.

WIN-68

AMENABILITY TESTING OF HOMESTAKE NORTH ALICE MINE ORE. H. I. Viklund and E. J. Hammond. May 20, 1957. 23 p.

The results of laboratory amenability testing of an ore sample from the Homestake Mining Company, North Alice Mine, in the Big Indian Wash District of Utah, are presented. 
WIN-69

PRELIMINARY PILOT PLANT INVESTIGATION OF THE ACID IEACH CCD - SOLVENT EXTRACTION PROCESS AS APPLIED TO WHITE CANYON ORES. A. W. Griffith, H. E. Gardner and R. L. Shimin. April 12, 1957. $43 \mathrm{p}$.

The preliminary operation of the Acid Leach - CCD Solvent Extraction Pilot Plant at Grand Junction, Colorado, was conducted from November 8, 1956 to January 3, 1957 using White Canyon ores. The report contains information on the grinding, leaching, and liquid-solid separation by continuous countercurrent decantation. Detailed information is presented on the liquid-liquid solvent extraction of the leach liquor using organic solvents containing di-2-ethylhexyl phosphopic acid or triisooctyl amine. Results show White Canyon ores to be amenable to the Acid Leach - CCD - Solvent Extraction process. Using di-2-ethylhexyl phosphoric acid, reagent consumptions were relatively high, whereas with triisooctyl amine excellent recovery of uranium was obtained with moderate reagent requirements.

WIN-70

ACID IEACH RESIN-IN-PULP PILOT PLANT TESTING OF MONTICELLO BLEND ORE. A. W. Griffith, M. A. Peters, W. D. Charles and H. E. Gardner. March 28, 1957. 59 p.

Uranium ore from the Monticello, Utah, stockpile consisting of 40 per cent Stockpile 68, 40 per cent Stockpile 56, and 20 per cent Stockpile 30 was treated in the Acid Leach - Resin-In-Pulp Pilot Plant at Grand Junction, Colorado, from June 15 through August 31, 1956. The name Monticello Blend was given the above mixture. This report presents information on leaching, ion exchange, solvent extraction of pregnant eluate, precipitation, and tailing neutralization tests obtained while treating Monticello Blend. From the pilot plant test, it was concluded that the ore is amenable to the Resin-In-Pulp process.

WIN-71

IABORATORY INVESTIGATION OF SCHWARTZWAIDER RAISTON CREEK ORE •

B. S. Porter and H. I. Viklund. November 4, 1957. $30 \mathrm{p}$.

The results of metallurgical tests of samples of ore from the Schwartzwalder Mine, Ralston Creek Area, Colorado, are reported. 
WIN-72

PIIOT PIANT INVESTIGATION OF THE ACID IEACH - FILTRATION SOLVENT EXTRACTION PROCESS AS APPLIED TO RIO de ORO DYSART SHAFT ORE. R. G. Beverly, D. O. Skiles and R. I. Shimmin. March 29, 1957. $57 \mathrm{p}$.

From January 4 to February 18, 1957, operation of the Aoid Leach - Filtration - Solvent Extraction Pilot Plant was studied with Rio de Oro Dysart Shaft ore from the Ambrosia Lake area in New Mexico as the ore feed. This report contains information on grinding and leaching of the ore, filtration of the leach residue, solvent extraction of the leach liquor, stripping of the pregnant solvent, and precipitation of yellow cake. The test work was divided into two periods. The first period was conducted with triisooctyl amine as the solvent extractant. High solvent entrainment losses and precipitation of a molybdenum - amine compound in the solvent circuit led to the second period of test work during which Amine 9D-178 was the extractant.

WIN -73

PILOT PLANT STUDIES OF ATMOSPHERIC AND PRESSURE IEACHING OF URANIUM ORES IN ALKALINE SOLUTIONS. R。G. Beverly, W. A. Millsap, and G. Winslow. June 11, 1957. 39 p.

During 1955 and 1956 numerous studies were made in the Alkaline Leach - Filtration Pilot Plant at Grand Junction, Colorado, comparing leach results in an autoclave and Pachuca tanks. These studies were made on several different ores including LaSal, Utex, Todilto Limestone, and Rio de Oro Dysart Shaft. The report presents the results of these studies and the effect of several variables such as contact time, temperature, and partial pressure of oxygen a variable which is determined not only by the total pressure of the system and the vapor pressure of water, but also by the rate at which consumed oxygen is replaced. Estimated utility costs for operation of different leaching equipment used are also presented. The report concludes that increasing temperature reduces contact time appreciably, and total air addition can be reduced by use of higher pressures. Leaching under pressure requires less steam and power than at atmospheric pressure.

WIN -74

AMENABILITY TESTING OF IAKEVIEW ORES。 D. $R_{0}$ George and R. U. Johnson. August 15, 1957. 38 p。

This report presents the results of laboratory amenability testing of five samples of ore from the Lucky Lass and White King Claims of the Lakeview Mining Company in Lake County, Oregon. The test work includes acid and carbonate leaching, settling and filtration testing, 


\section{WIN-74 (Continued)}

and Ion exchange of acid leach liquors. Rather extensive investigations of the use of solvents to extract the uranium have been made and the results are being presented in a separate report.

WIN -75

PIIOT PIANT TESTING OF SOLVENT EXTRACTION OF ACID RIP PREGNANT ELUATES. W. D. Charles, H. E. Gardner, M. A. Peters, and R. L. Shimmin. June 10, 1957. 42 p.

From May 10 to October 29, 1956, sulfuric acid elution was substituted for nitrate elution in the Acid Resin-In-Pulp Pilot Plant. The pregnant eluate was subjected to solvent treatment in a pulse colurm and in mixer-settlers. The extractant was di-2-ethyl hexyl phosphoric acid. The report contains detailed information on sulfuric acid elution of ion exchange resin, solvent extraction of pregnant eluate, and precipitation of pregnant carbonate solution.

WIN-76

ACID IEACH CCD - COLUMNS PILOT PLANT TESTING OF RIO de ORO DYSART SHAFT ORE. W. A. Millsap and R. I. Shimmin. November I, 1957. $36 \mathrm{p}$.

During the period of January 8 to February 18, 1957, Rio de Oro Dysart. Shaft ore from the Ambrosia Lake District of New Mexico was treated in the Acid Leach - CCD - Columns Pilot Plant at Grand Junction, Colorado. The report contains detailed information on the liquid - solid separation by continuous countercurrent decantation, ion exchange, and precipitation in connection with the processing of this ore. A section is included on mill design considerations. Results show the ore to be amenable to the Acid Ieach - CCD - Ion Exchange Columns process.

WIN-77

THE ALKAIINE LEACH - RESIN-IN-PULP PROCESS AS APPLIED TO TODILTO, MESA TOP, AND ILA SAL ORES. P. N. Thomas and R. I. Shimnin. September 10, 1957. $106 \mathrm{p}$.

Test work toward development of the Alkaline Leach Resin-InPulp process has been conducted. Todilto Stockpile 53 ore from the Grants, New Mexico area was treated from April 7, to June 18, 1956, Mesa Top ore from the Ambrosia Lake district from June 22 to August 26, 1956, and LaSal ore from December 11 through December 24, 1956. The 
WIN-77 (Continued)

report contains data on leaching, reagent recovery, sand-slime separation, ion exchange, and precipitation characteristics of those ores. The data show that the ores reported herein are amenable to the Alkaline Leach-RIP process.

WIN-78

ACID IEACH RESIN-IN-PUIP AND CCD SOLVENT EXTRACTION PILOT PLANT TESTING OF IAKEVIEW ORE. W. A. Millsap and R. I. Shimin. March, 1958. 54 p.

During the period of February 21 to May 30, 1957, Lakeview ore from the Lakeview Mining District of Oregon was treated in the Acid Leach RIP Pilot Plant and the Acid Leach - CCD - Solvent Extraction Pilot Plant at Grand Junction, Colorado. Both Lakeview Oxidized and Reduced Ores from the White King claim were tested. The report contains detailed information on grinding, leaching, sand-slime separation, countercurrent decantation, ion exchange, solvent extraction, and precipitation in connection with the processing of this ore. Results show the ores to be amenable to both processes. However, frequent regeneration of the resin would be required when treating Lakeview Reduced Ore in an Acid Leach RIP process.

WIN -79

ALKALINE IEACH - FIITRATION PILOT PIANT TESTING OF GLOBE MINING COMPANY ORE. G. R. Pitmon and G. Winslow. October 18, 1957. $37 \mathrm{p}$.

During the period of May 17 to June 22, 1957, Globe Mining Company ore from the Gas Hills district of Wyoming was treated in the Alkaline Leach - Filtration Pilot Plant at Grand Junction, Colorado. The report contains detailed information on grinding, leaching, filtration, and precipitation in connection with the processing of this ore. Pachuca leaching was employed and results show the ore to be amenable to the Alkaline Leach - Filtration process.

WIN-80

ALKALINE IEACH - FILTRATION PILOT PLANT TESTING OF GLOBE-VITRO BLEND. G. R. Pitmon and G. Winslow. December 12, 1957. 32 p.

During the period of April 11 to May 17, 1957, a blend of Globe Mining Company and Vitro Stockpile ores from the Gas Hills district of Wyoming was treated in the Alkaline Leach - Filtration 
WIN-80 (Continued)

Pilot Plant at Grand Junction, Colorado. This report contains detailed information on grinding, leaching, filtration, and precipitation in connection with the processing of this ore. Pachuca leaching was employed and the circuit liquors contained organic material that was detrimental to clarification and precipitation and the results show that the ore was not amenable to the Alkaline Leach - Filtration process unless a special additive was used.

WIN-8I

PILOT PIANT TESTING OF DAKOTA IIGNITES. G. R. Pitmon, M. A. Peters, G. Winslow, H. E. Gardner and R. L. Shimmin. October 18, 1957. $142 \mathrm{p}$.

The report deals with the pilot plant investigation of recovering uranium from Dakota lignites. Details on Fluosolids roasting, acid leaching, washing and solvent extraction are presented.

WIN-82

ALKAIINE IEACH RESIN-IN-PULP PILOT PLANT TESTING OF URANIUM REDUCTION BLEND. H. E. Gardner, M. A. Peters, G。 Winslow and R. L. Shimmin. January 15, 1958. 58 p.

During the period August 15 to November 2, 1957, a blend of ores to be processed by the Uranium Reduction Company, Moab, Utah, was treated in the Alkaline Leach - RIP Pilot Plant at Grand Junction, Colorado. The report contains detailed information on grinding; leaching, reagent recovery, sand-slime separation, ion exchange, and precipitation as related to the processing of this ore. Autoclave leaching was employed and results show the ore to be amenable to the Alkaline - RIP process.

WIN-83

ALKALINE IEACH RESIN-IN-PULP PILOT PLANT TESTING OF MONUMENT VALIEY ORE. W. D. Charles and R. L. Shimmin. June 1, 1958. $43 \mathrm{p}$.

During the period of November 27, 1955 through January 31, 1956, various portions of the Monument Valley ore, Monticello Stockpile 46, were treated in the Alkaline Leach Resin-In-Pulp Pilot Plant at Grand Junction, Colorado, to study ion exchange characteristics with a low uranium to vanadium ratio in the ion exchange feed. The uranium to vanadium concentrations were such that a ratio as low as 


\section{WIN-83 (Continued)}

1.5:1 was attained with no detrimental effect on the ion exchange characteristics. The report contains detailed information on grinding, leaching, sand-slime separation, ion exchange, and precipitation as related to the processing of this ore.

\section{WIN -84}

ALKALINE IEACH - CED - COLIMN ION EXCHANGE PILOT PIANT TESTING OF AMBROSIA IAKE ORES. H. L. Ford, J. R. Ruark, and R. I. Shimin. June 16, 1958. 54 p.

Test work devoted to development of the Alkaline Leach CCD - Column Ion Exchange Process was performed at the Grand Junction Pilot Plant from November 4, 1957 to February 2, 1958. This report presents data on leaching, reagent recovery, countercurrent decantation, column ion exchange, and precipitation characteristics of the Rio de Oro Dysart Shaft and Holly Minerals Company ores from the Grants, New Mexico area.

WIN-85

THE USE OF POWDERED SPECIMENS FOR STUDYING THE KINETICS OF DISSOLUTION. W. E. Schortmann and M. A. DeSesa. November 18, 1957. $34 \mathrm{p}$.

Because of the difficulty involved in preparing massive specimens, the feasibility of using powdered material in kinetic studies of liquid-solid systems was investigated. It was shown that, contrary to published opinion, the powder method for studying the dissolution of solids is as valid as the massive specimen technique. Consequently, the advantages of using a fine powder warrant consideration of its use in studying the kinetics of these heterogeneous systems. The main advantages are ease of sample acquisition and preparation and simplicity of experimental procedure.

WIN-86

QXIDANTS IN CARBONATE IEACHING OF URANIFEROUS ORES. P. J. Magno and M. A. DeSesa. August 23, 1957. 44 p.

In order to obtain data on the comparative effectiveness of oxidants for uranium in alkaline carbonate solutions, a variety of reagents were used under identical conditions for the dissolution of uranium dioxide in $0.5 \mathrm{M}$ sodium carbonate and $0.5 \mathrm{M}$ sodium bicarbonate. Those oxidants which appeared most promising were evaluated further in 


\section{WIN-86 (Continued)}

leaching studies on E. I. Cord and La Sal ore samples. As a result of these tests, the cupric ammonia complex ion was determined to be the most "economical oxidant for the carbonate leaching of uraniferous ores. Further evaluation of the copper-ammonia reagent on other ores, which were known to require an oxidant during carbonate leaching, indicated that this reagent is effective on all ores tested.

WIN-87

IABORATORY INVESTIGATION OF MOONLIGHT CLAIM ORE. E. S. Porter, H. I. Viklund and E. J. Hammond. March 3, 1958. 19 p.

The results of laboratory metallurgical investigations of a sample of ore from the Moonlight Claim of the Industrial Minerals Corporation are reported. The amenability of the sample to acid and carbonate leaching techniques and methods of recovery of uranium from acid solution were studied.

WIN -88

IABORATORY STUDIES IN CARBONATE ION EXCHANGE FOR URANIUM RECOVERY. E. T. Hollis. MaY 1, 1958. 52 p.

The (results of laboratory studies on sodium carbonate ion exchange are shown. The effect of salt concentration, uranium concentration, and possible interference with ion exchange from vanadium, molybdenum, sulfate and chloride are discussed. Various elution systems and the effect of residual uranium are described. A short discussion of ammonium carbonate ion exchange is also presented.

\section{WIN-89}

KINETICS OF THE DISSOLUTION OF URANIUM DIOXIDE IN CARBONATEBICARBONATE SOLUTIONS. W. E. Schortmann and M. A. DeSesa. March 12, 1958. $62 \mathrm{p.}$

The kinetics of the dissolution of uranium dioxide in sodium carbonate-sodium bicarbonate solutions were determined. The study was undertaken in order to obtain fundamental information about the commercial carbonate process for leaching uranium from its ores. A rate equation incorporating the effects of surface area, oxygen partial pressure, temperature, and reagent concentrations was empirically developed. A mechanism consisting essentially of two consecutive reactions at steady state is proposed. These reactions are the oxidation of $U(I V)$ to $U(V I)$ and the subsequent formation of the uranyl dicarbonate complex ion. Depending on the conditions, 
WIN-89 (Continued)

either or both of these reactions can determine the over-all rate. The conversion of uranyl dicarbonate to the uranyl tricarbonate complex ion is postuzated to be very rapid. In the suggested mechanlsm, the rate-determining phase of the oxidation is the dissociation of adsorbed molecular oxygen, and both the carbonate and bicarbonate ions play equivalent roles in the formation of the uranyl dicarbonate. As indicated by their high activation energies of about 13 and $14 \mathrm{kcal}$ per mole uranium, both reactions are chemical rather than diffusional processes. A mathematical examination of the proposed mechanism produced a rate equation consistent with the experimental information. The credibility of the mechanism was thereby strengthened.

WIN-90

PREPARATION OF DENSE, MRTAL-GRADE UF 4 FROM ORES AND CONCENTRATES. H. G. Petrow, R. J. Allen and P. J. Magno. May 15; 1958. 64 p.

A process for the preparation of dense, metalgrade $\mathrm{UF}_{4}$ from ores and concentrates 18 described.

WIN-91

AMENABILITY TESTING OF LABAJADA ORE. R. U. Johnson. April 17, 1958. 15 p.

Data are presented on the resulta of acid and carbonate leaching studies on samples of ore from the LaBajada Mine of the Ione Star Mining Company, Santa Fe County, New Mexico. 
WIN-115

WIN-92

Not for general distribution.

WIN-93

Unused number.

WIN -94

Unused number.

WIN -95

THE DEHYDRATION OF GRESN SALT, UF 4 . A. Whitman and

R. Lindstrom. May 1, 1959. 40 p.

Several methods have been investigated for the dehydration of green salt produced by preclpitation from aqueous solution. As a result of this investigation a procedure was devised in which metal-grade salt was produced by dehydration in a tube furnace at $400-500^{\circ} \mathrm{C}$. Bsing this method, no special furnace atmosphere is required. An air flush is used to provide the proper oxidation after most of the molsture is removed from the salt. The method was successfully used to dehydrate almost 200 pounds of green salt.

WIN-96

AMENABILITY TESTING OF ST. ANTHONY ORE. H. I. Viklund and B. J. Hammond. May 9, 1958. 13 p.

The results of laboratory amenablilty tegting of an ore sample from the St. Anthony Urantum Corporation, In Valenoia County, New Mexico, are presented.

WIN-97

AMENABILITY TESTIMG OF ORB SAMPIBS FRCA THE CAS HIIIS DISTRICT OF WYOMING. H. I. VIklund, B. J. Hamond and R. U. Johnson. July 10, 1958. $22 \mathrm{p}$.

Date are presented to show that varlous ores from the ars Hills area of Wyoming are amenable to leaching with acld or carbonate solutions. The effect of soluble organic matter in the ores is considered. 
WIN-115

WIN-98

IABORATORY INVESTIGATION OF MALLINCKRODT BOMB LINER SLAG. B. S. Porter. June 13, 1958. 49 p.

Data are given for leaching Mallinckrodt magnesium fluoride and dolomite slag in acid and alkaline systems. Recovery of dissolved values is considered using direct precipitation, ion exchange, or solvent extraction.

WIN -99

CHEMICAL STREAM POLLUTION FROM URANIUM MILIS. A. Whitman and E. S. Porter. June 13, 1958. 43 p.

A study of chemical pollution of water supplies caused by tailings discharge from domestic urantum milis is presented. State water specifications are surveyed, the extent and nature of pollution are evaluated, and remedies are suggested.

WIN-100

CONTINUOUS COUNTERCURRENT SOLVENT IRACHING. P. Galvanek, Jr. July 16, $1958.43 \mathrm{p}$.

Continuous countercurrent non-aqueous leaching techniques are described for the recovery of uranium directly from a variety of conditioned ores. No preliminary gangue separation is involved. Product grades exceeding 99 per cent ${ }_{3} 0_{8}$ are achleved. Several methods for uranium solubilization and ore conditioning by the acid-cure technique are described. Both primary and secondary ores were successfully treated. A bibliography of literature pertaining to the solvent leaching techique from its inception is included.

WIN -101

INTERDM REPORT ON INVESTIGATIONS INTO THE PROBLEM OF RADIOACTIVE POLLUTION OF URANIUM MILI EFTLUENTS. M. A. DeSesa. December 15, 1958. $61 \mathrm{p}$.

A review of the laboratory investigations to date into the problem of radioactive pollution of uranium mill effluents - is presented. The scope of the problem is defined, preliminery survey data are outlined, and detalled investigations into means of alleviating the problem are presented. 
WIN-115

WIN-102

A CONTINUOUS COUNTERCURRENT RESIN-IN-PULP PROCESS. J. B. Breymann, E. T. Hollis and J. T. Lynch. July 18, 1958. $32 \mathrm{p}$.

Data are reported for a continuous 1375 pound per day pilot plant run of a countercurrent resin-in-pulp process using air agitated tanks and conventional vibrating screens in the adsorption circuit and continuous countercurrent colum elution in the recovery circuit. Some data are given to indicate the physical stability of varlous anion exchange resins in use in this type of process.

WIN -103

CONTROL OF ORGANICS IN CARBONATE IEACHING CIRCUITS. D. R. GeOrge and J. T. Lymch. July 25, 1958. 35 p.

The results of experiments with methods of controling soluble organics in the carbonate leaching of uranium ores are described. The methods studied Include the uses of adsorbents, chemical oxidants, preolpitants, electrolytic oxidation, and air oxidation by high-temperature autoclaving.

WIN-104

SQME EXPERTMENTS WITH AERATION AND AGITATION OF CARBONATB LEACHING SLURRTES. G. W. Clevenger and R. A. Eisenhauer. June 23, 1958. 28 p.

Data are presented on the effect of varlous amounts and methods of aeration on uranium leaching extraction and power requirements of mechanical agltators. The effect of tank depth on air oxidation is considered.

WIN-105

LABORATORY INVESTIGATION OF SINGLE-STAGE AND CONTINUOUS COUNTERCURRENT ION EXCHANGB METHODS. E. T. HOLIis and R. J. Woody. July 1, 1958. 36 p.

The report describes the initial stages of the development of methods of continuous ion exchange processes including (1) a combination of two stage leaching and recovery of uranium in a single stage resin-in-pulp contact, (2) elution of uranium 
WIN-105 (Continued)

In a continuous countercurrent column and (3) exhaustion of uranium from leach liquor in the continuous countercurrent column. Test results are also presented on the effect of variables on resin loading and uranium recovery by single stage contact for solution to resin ratios in the range of 25-100 to one.

WIN -106

ALKALINE IEACH - FILTRATION PILOT PIANT TESTING OF MONTICELIO BLEND OF HIGH LIME ORES. H, E. Dixon and G. Winslow. March 14, 1958. $32 \mathrm{p}$.

During the period of January 2 to January 23, 1958, a blend of LaSal, Standard, and Jen ores from the Monticello stockpiles was treated in the Alkaline Leach - Filtration Pilot Plant at Grand Junction, Colorado. This report contains detailed information on grinding, leaching, filtration, and precipltation in connection with the processing of this ore. Autoclave leaching and continuous $\mathrm{NaOH}$ precipitation were employed. The results show the ore to be amenable to the Alkaline Leach - Filtration process.

WIN -107

ALKALINE LEACH - FILTRATION PILOT PIANT TESTING OF HOMBSTAKE ORT - SRCTION 32. H. E. Dixon and G. Winslow. June 9, 1958. $33 \mathrm{p}$.

During the period of January 23 to February 12, 1958, Homestake Ore (Section 32) from the Ambrosia Lake District of New Mexico was treated in the Alkaline Leach - Filtration Pilot Plant at Grand Junction, Colorado. This report contains detailed information on grinding, leaching, filtration, and precipitation in connection with the processing of this ore. Autoclave leaching and continuous yellow cake precipitation were employed. The circuit liquors contained organic material that was detrimental to clarification and precipitation and the results show that the ore was amenable to the Alkaline Leach - Filtration process only if a special additive was used. 
WIN-115

WIN-108

ALKALINE LEACH - FILTRATION PILOT PLANT TESTING OF HOLLY MINERALS COMPANY ORE. H. E. Dixon and G. Winslow. June 9, 1958. $43 \mathrm{p}$.

During the period of February 15 through April 1, 1958, Holly Minerals Company ore from the Ambrosia Lake District of New Mexico was treated in the Alkaline Leach - Filtration Pilot Plant at Grand Junction, Colorado. The report contains detalled information on grinding, leaching, filtration, and precipitation in connection with the processing of this ore. Both autoclave and Pachuca leaching were employed. Results show the ore to be amenable to the Alkaline Leach - Filtration process.

WIN-109

ACID LEACH-CCD-SOLVENT EXTRACTION PILOT PLANT TESTING OF HOLLY MINRRALS COMPANY ORE. M. A. Peters and R. L. Shimmin. June 20, 1958. $66 \mathrm{p}$.

During the period of February 10 to May 8, 1958, Holly Blend ore from the Holly Minerals Company of the Ambrosia Lake District in New Mexico was treated in the Acld Leach - Countercurrent Decantation - Solvent Extraction Pilot Plant at Grand Junction, Colorado. This report contalns detailed information on leaching, countercurrent decantation, clarification, and solvent extraction as applied in the processing of this ore. Results show the ore to be amenable to the Acid Leach - Countercurrent Decantation - Solvent Extraction process.

WIN -110

ALKALINE IEACH - FILTRATION PILOT PIANT TESTING OF PHILILIPS PBTROLEUM COMPANY ORE. H. E. DIXon and G. Winslow. July 1, 1958. $54 \mathrm{p}$.

During the period of April 3 through May 28, 1958, Phillips Petroleum Company ore (Section 28) from the Ambrosia Lake District of New Mexico was treated in the Alkaline Leach Filtration Pilot Plant at Grand Junction, Colorado. This report contains detailed information on grinding, leaching, filtration, and precipitation in connection with the processing of this ore. Both pressurized and atmospheric Pachuce leaching followed by filtration and continuous yellow cake preclpitation were employed. The results show that the ore was amenable to the Alkaline Leach Filtration process. 
WIN-1.11

SECOND INTERIM PEPORT ON INVESTIGATIONS INTO THE PROBLEM OF RADIO-ACTIVE POLLUTION OF URANIUM MILL EFFLUENTS. M. A. DeSesa. April 1, 1959. 75 p.

A review of the laboratory and plant investigations for the period December 16, 1958 to March 31, 1959 into the problem of radioactive pollution of uranium mill effluents is presented.

WIN -112

THIRD INTERIM REPORT ON INVESTIGATIONS INTO THE PROBIEM OF RADIO-ACTIVE POLLUTION OF URANIUM MILI EFFLUENTS. R. G. Beverly September 30, 1959. 112 p.

A review of the laboratory and plant investigations conducted between April 1, 1959 and September 1, 1959 into the problem of radioactive pollution from uranium mill effiuents is presented, methods of decontamination for radium and thorium, treatment studies on acid and alkaline mill tailings, U-Ra-Th equilibrium ratios in ores, and $\mathrm{Ra}-\mathrm{Th}$ balances in uranium mills are discussed.

WIN-113

RADIUM BAIANCE IN THE MONTICELLO ACID R.I.P. URANIUM MILL. A. Whitman and R. G. Beverly. December 30, 1958. 48 p.

i study of radium distribution through the Monticello Acid Resin-in-Pulp plant is presented. Emphasis is placed on the flow of radium through the process in an effort to determine the effect of the vranium treatment process on the dissolution and the ultimate disposition of radium.

WIN -114

SURVEY AND PREVENTION TECHNIQUES FQR CONTROL OF RADIOACTIVITY HAZARDS AT THE MONTICELLO URANIUM MILL. R. G. Beverly. December 15, 1958. 65 p.

This report describes the techniques used in sampling, analyzing, and evaluating results for determining hazards from external radiation, airborne radioactive material, radioactive 
WIN-115

\section{WIN-114 (Cont'd)}

contaminants in mill effluents, and urinary uranium, as applied to the Monticelio, Utah, uranium mill. Corrective measures used by National Iead Company, Inc., at the Monticello Mill are described along with the results from later surveys which showed large reductions in the potential radiation hazards. Details are given of the methods used to determine personnel exposures to radioactive and sllicosis-producing dusts, potential external radiation hazards and in assaying mill effluents for uranium and radium, assaying urine samples for urantum, as well as the standard operating procedures issued at Montlcello to employees for preventing and/or controlling personnel exposures. 
TOPICAL REPORTS

AMERICAN CYANAMID COMPANY

(From ACCO-67)

\begin{tabular}{|c|c|c|c|}
\hline Number & Authors & Title & $\begin{array}{l}\text { Date of } \\
\text { Issue }\end{array}$ \\
\hline ACCO-1 & & Progress Report & $3 / 51$ \\
\hline $\mathrm{ACCO}-2$ & Woody & $\begin{array}{l}\text { Possible Substitutes for Glue } \\
\text { in South African Ore Treatment }\end{array}$ & $5 / 51$ \\
\hline $\mathrm{ACCO}-3$ & & Progress Report & $5 / 51$ \\
\hline $\mathrm{ACCO}-4$ & & Progress Report & $8 / 51$ \\
\hline $\mathrm{ACCO}-5$ & $\begin{array}{l}\text { Abrams, } \\
\text { Woody }\end{array}$ & $\begin{array}{l}\text { Leaching and Precipitation } \\
\text { Tests on Grants Ores }\end{array}$ & $9 / 51$ \\
\hline ACCO-6 & & Progress Report & $11 / 51$ \\
\hline $\mathrm{ACC} 0-7$ & $\begin{array}{l}\text { Brunner, } \\
\text { George, } \\
\text { Rubino }\end{array}$ & $\begin{array}{l}\text { Preliminary Report on Recovery } \\
\text { of Uranium from Low Grade } \\
\text { Belgian Congo Ores }\end{array}$ & $10 / 51$ \\
\hline $\mathrm{ACCO}-8$ & Abrams & $\begin{array}{l}\text { Ion-Exchange Studies on Carbonate } \\
\text { Leach Liquors from Grants, New } \\
\text { Mexico Ores }\end{array}$ & $10 / 51$ \\
\hline $\mathrm{ACCO}-9$ & $\begin{array}{l}\text { George, } \\
\text { Kennedy, } \\
\text { Howland, } \\
\text { Rubino }\end{array}$ & $\begin{array}{l}\text { Preliminary Report on Recovery } \\
\text { of Uranium from High Carbonate } \\
\text { Belgian Congo Uranium Ores }\end{array}$ & $10 / 51$ \\
\hline ACCO-10 & Breymann & $\begin{array}{l}\text { Application of Heavy Media } \\
\text { Separation, Flotation and } \\
\text { Carbonate- Leaching to Congo } \\
\text { Ores }\end{array}$ & $10 / 51$ \\
\hline ACCO-11 & $\begin{array}{l}\text { Kennedy } \\
\text { Howland }\end{array}$ & $\begin{array}{l}\text { Recovery of Uranium from Congo } \\
\text { Leach IIquors with Ion Exchange } \\
\text { Resins }\end{array}$ & $10 / 51$ \\
\hline $\mathrm{ACCO}-12$ & $\begin{array}{l}\text { Pannell, } \\
\text { Michal, } \\
\text { Thorpe, } \\
\text { Lower, } \\
\text { Bloecher }\end{array}$ & $\begin{array}{l}\text { Elution of Uranium from Anion } \\
\text { Exchange Resins by Pregnant } \\
\text { Rand Solutions }\end{array}$ & $4 / 53$ \\
\hline
\end{tabular}


ACCO REPORTS

(Continued)

\begin{tabular}{|c|c|c|c|}
\hline Number & Authors & Title & $\begin{array}{l}\text { Date of } \\
\text { Issue }\end{array}$ \\
\hline $\mathrm{CCO}-13$ & Bloecher & $\begin{array}{l}\text { Filtration, Drying and Calcining } \\
\text { Tests on Rand Precipitates }\end{array}$ & $11 / 51$ \\
\hline $\mathrm{CCO}-14$ & Bloecher & $\begin{array}{l}\text { Calcining-Amenability Testing of } \\
\text { Rand Precipitates }\end{array}$ & $11 / 51$ \\
\hline $\mathrm{CCO}-15$ & & Progress Report & $12 / 51$ \\
\hline ACCO-16 & Bloecher & $\begin{array}{l}\text { Uranium Recovery from Thomas } \\
\text { Range, Utah Fluorspar }\end{array}$ & $1 / 52$ \\
\hline$A C C O-17$ & & Progress Report & $1 / 52$ \\
\hline$A C C O-18$ & $\begin{array}{l}\text { R. Hollis, } \\
\text { Breymann, } \\
\text { Lynch }\end{array}$ & $\begin{array}{l}\text { Preliminary Leaching Investiga- } \\
\text { tion of Ores from Radium Hill, } \\
\text { South Australia }\end{array}$ & $6 / 52$ \\
\hline$A C C 0-19$ & Clevenger & $\begin{array}{l}\text { Experimental Work for the Develop- } \\
\text { ment of a Process to Treat Luka- } \\
\text { chukai Ores }\end{array}$ & $6 / 52$ \\
\hline $\mathrm{ACCO}-20$ & & Progress Report & $4 / 52$ \\
\hline$A C C O-2 I$ & $\begin{array}{l}\text { R. Hollis, } \\
\text { Lynch }\end{array}$ & $\begin{array}{l}\text { Preliminary Leach Investigation } \\
\text { of Babrosco and Afrikander Lease } \\
\text { Residues }\end{array}$ & $5 / 52$ \\
\hline$c \in 0-22$ & George & $\begin{array}{l}\text { Recovery of Uranium by Ion Exchange } \\
\text { or by Uranous Phosphate Precipita- } \\
\text { tion from Sulfuric Acid Leach Solu- } \\
\text { tions Produced from Austraílian } \\
\text { Davidite Ore Concentrates }\end{array}$ & $6 / 52$ \\
\hline $\mathrm{CCO}-23$ & Owens & $\begin{array}{l}\text { Recovery of Manganese Dioxlde from } \\
\text { Rand Barren Solutions }\end{array}$ & $3 / 52$ \\
\hline $\mathrm{CCO}-24$ & George & $\begin{array}{l}\text { Recovery of Uranium from High Grade } \\
\text { Australian Rum Jungle Uranium Ore }\end{array}$ & $8 / 52$ \\
\hline $\mathrm{CCO}-25$ & Clevenger & $\begin{array}{l}\text { A Regenerative Electrolytic Process } \\
\text { for Recovering Uranium from Ores }\end{array}$ & $8 / 52$ \\
\hline $\operatorname{cco}-26$ & $\begin{array}{l}\text { Abrams, } \\
\text { Kaufman }\end{array}$ & $\begin{array}{l}\text { Preliminary Studies of the Adsorp- } \\
\text { tion of Uranium in a Resin-In-Pulp } \\
\text { System }\end{array}$ & $7 / 53$ \\
\hline
\end{tabular}


WIN-115

\section{ACCO REPORTS}

(Continued)

\begin{tabular}{|c|c|c|c|}
\hline Number & Authors & Title & $\begin{array}{l}\text { Date of } \\
\text { Issue }\end{array}$ \\
\hline $\mathrm{ACCO}-27$ & Bloecher & $\begin{array}{l}\text { Uranium Recovery from a Temple } \\
\text { Mountain District Ore Sample }\end{array}$ & $10 / 52$ \\
\hline ACCO-28 & $\begin{array}{l}\text { Breymann, } \\
\text { George }\end{array}$ & $\begin{array}{l}\text { Tests on Samples of Copper- } \\
\text { Uranium Ore from Rum Jungle } \\
\text { Deposit, Northern Territory, } \\
\text { Australia }\end{array}$ & $1 / 53$ \\
\hline$A C C 0-29$ & Clevenger & $\begin{array}{l}\text { The Application of the Electrolytic } \\
\text { Uranium Recovery Process to Lime- } \\
\text { stone Ore from Grants, New Mexico }\end{array}$ & $9 / 53$ \\
\hline$A C C O-30$ & $\begin{array}{l}\text { Abrams, } \\
\text { Moulton, } \\
\text { Viklund }\end{array}$ & $\begin{array}{l}\text { Preliminary Leaching Tests for } \\
\text { the Extraction of Uranium from } \\
\text { Various Monticello Stockpile Ores }\end{array}$ & $3 / 53$ \\
\hline ACCO-31 & Kennedy & $\begin{array}{l}\text { Examination of Poisoned Ion Exchange } \\
\text { Resins from the Western Reefs Pilot } \\
\text { Plant }\end{array}$ & $2 / 53$ \\
\hline$A C C O-32$ & Brown & $\begin{array}{l}\text { Metallurgical Investigation of } \\
\text { Various Grants, New Mexico, Iime- } \\
\text { stone Ores }\end{array}$ & $5 / 53$ \\
\hline ACCO-33 & $\begin{array}{l}\text { Jones, } \\
\text { Viklund }\end{array}$ & $\begin{array}{l}\text { Additional Extraction and Ion Ex- } \\
\text { change Studies of Temple Mountain } \\
\text { District Ores }\end{array}$ & $7 / 54$ \\
\hline $\operatorname{ACCO}-34$ & $\begin{array}{l}\text { Viklund, } \\
\text { Kennedy }\end{array}$ & $\begin{array}{l}\text { Removal of Chloride from Congo } \\
\text { Precipitates }\end{array}$ & $11 / 53$ \\
\hline ACCO-35 & $\begin{array}{l}\text { Schiff, } \\
\text { Lower, } \\
\text { E. Hollis }\end{array}$ & $\begin{array}{l}\text { The Effect of Molybdenum on Uranium } \\
\text { Adsorption and Subsequent Cyclic } \\
\text { Column Testing of Leach Liquor }\end{array}$ & $3 / 54$ \\
\hline ACCO -36 & Brown & $\begin{array}{l}\text { Preliminary Investigation of Carbon- } \\
\text { ate Leaching }\end{array}$ & $10 / 53$ \\
\hline$A C C O-37$ & Plckwlck & $\begin{array}{l}\text { Ion Exchange Studies on Acld Leach } \\
\text { Liquors from Durango Residues }\end{array}$ & $1 / 54$ \\
\hline
\end{tabular}


ACCO REPORTS

(Continued)

\begin{tabular}{|c|c|c|c|}
\hline Number & Authors & Title & $\begin{array}{c}\text { Date of } \\
\text { Issue }\end{array}$ \\
\hline$A C C O-38$ & Breymann & $\begin{array}{l}\text { Progress Report on the Flotation } \\
\text { of Uranium Bearing Minerals from } \\
\text { Lake Athabaska Ore, Sample 43-1 }\end{array}$ & $10 / 53$ \\
\hline ACCO-39 & $\begin{array}{l}\text { Breymann, } \\
\text { Richardson }\end{array}$ & $\begin{array}{l}\text { A Copper-Uranium Ore from Rum Jungle, } \\
\text { Northern Territory, Australia }\end{array}$ & $11 / 53$ \\
\hline $\operatorname{ACCO}-40$ & Clevenger & $\begin{array}{l}\text { A Pilot Plant Test of the Electroly- } \\
\text { tic Uranium Recovery Process }\end{array}$ & $6 / 54$ \\
\hline ACCO-4I & $\begin{array}{l}\text { Stanley, } \\
\text { George, } \\
\text { Thomas, } \\
\text { Eisenhauer, } \\
\text { Lynch, } \\
\text { Richardson }\end{array}$ & $\begin{array}{l}\text { Utex Leaching, Thickening and F11- } \\
\text { tration Tests }\end{array}$ & $3 / 54$ \\
\hline $\mathrm{ACCO}-42$ & $\begin{array}{l}\text { R. Hollis, } \\
\text { Abrams, } \\
\text { McArthur, } \\
\text { Izzo }\end{array}$ & $\begin{array}{l}\text { The Development of a Resin-in-Pulp } \\
\text { Process and its applications to ores } \\
\text { of the White Canyon Area of Utah }\end{array}$ & $6 / 54$ \\
\hline ACCO-43 & $\begin{array}{l}\text { E. Hollis, } \\
\text { Pickwick, } \\
\text { Kazanjian, } \\
\text { Larson, } \\
\text { Howland, } \\
\text { Porter }\end{array}$ & $\begin{array}{l}\text { Ion Exchange Tests on Liquors and } \\
\text { Pulps Produced from Utex Ores }\end{array}$ & $7 / 54$ \\
\hline $\mathrm{ACCO}-44$ & $\begin{array}{l}\text { Schiff, } \\
\text { Lower }\end{array}$ & $\begin{array}{l}\text { Investigations of Ion Exchange } \\
\text { Methods for Recovery of Uranfum } \\
\text { from Liquors Produced by Acld } \\
\text { Leaching of Gunnar Ore }\end{array}$ & $6 / 54$ \\
\hline $\mathrm{ACCO}-45$ & $\begin{array}{l}\text { E. Hollis, } \\
\text { McLean }\end{array}$ & $\begin{array}{l}\text { Precipitation of Red Cake from Low } \\
\text { Vanadium Acid Sulfate Leach Iiquors }\end{array}$ & $10 / 54$ \\
\hline ACCO-46 & $\begin{array}{l}\text { Schiff, } \\
\text { V1klund }\end{array}$ & $\begin{array}{l}\text { Recovery of Uranium from Vitro } \\
\text { Leach Iiquor by Ion Exchange, Part } \\
\text { II, Cyclic Column Tests Comparing } \\
\text { IRA-400 and XE-75 Resins and Cyclic } \\
\text { Testing of a Resin-in-Pulp System }\end{array}$ & $5 / 54$ \\
\hline
\end{tabular}


WIN-I15

- 73 -

ACCO REPORTS

(Continued)

\begin{tabular}{|c|c|c|c|}
\hline Number & Authore & Iftle & $\begin{array}{l}\text { Date of } \\
\text { Issue }\end{array}$ \\
\hline $\operatorname{ACCO}-47$ & $\begin{array}{l}\text { Galvanek, } \\
\text { Morrison }\end{array}$ & $\begin{array}{l}\text { A New Fluorimeter for the Deter- } \\
\text { mination of. Uranium }\end{array}$ & $5 / 54$ \\
\hline $\mathrm{ACCO}-48$ & Frank & $\begin{array}{l}\text { Summary of Carbonate Leaching of } \\
\text { Uranium Ores }\end{array}$ & $6 / 54$ \\
\hline ACCO-49 & Frank & $\begin{array}{l}\text { The Chemistry of Vanadium-A Summary } \\
\text { of Non-Project Literature through } \\
\text { November, } 1952\end{array}$ & $6 / 54$ \\
\hline ACCO-50 & $\begin{array}{l}\text { Thorpe, } \\
\text { Schiff, } \\
\text { Cole, } \\
\text { Plckwlck, } \\
\text { Lynch }\end{array}$ & $\begin{array}{l}\text { Ion Exchange of Grants Acid Leach } \\
\text { Liquors }\end{array}$ & $7 / 54$ \\
\hline $\mathrm{ACCO}-51$ & Stanley & Vanadium Salt Roasting Studies & $7 / 54$ \\
\hline $\mathrm{ACCO}-52$ & $\begin{array}{l}\text { Stanley, } \\
\text { Elsenhauer, } \\
\text { Richardson }\end{array}$ & $\begin{array}{l}\text { Two-Stage Leaching Tests on Utex } \\
\text { Ore }\end{array}$ & $7 / 54$ \\
\hline ACCO-53 & $\begin{array}{l}\text { Abrams, } \\
\text { Izzo }\end{array}$ & $\begin{array}{l}\text { The Recovery of Vanadium by Ion } \\
\text { Exchange }\end{array}$ & $7 / 54$ \\
\hline $\mathrm{ACCO}-54$ & $\begin{array}{l}\text { DeSesa, } \\
\text { Nietzel }\end{array}$ & $\begin{array}{l}\text { Spectrophotometric Determination } \\
\text { of Uranium with Thiocyanate }\end{array}$ & $7 / 54$ \\
\hline ACCO-55 & Zingaro & $\begin{array}{l}\text { Studies on Direct Extraction of } \\
\text { Uranium from Synthetic Ores by } \\
\text { Non-Aqueous Systems }\end{array}$ & $7 / 54$ \\
\hline $\operatorname{ACCO}-56$ & Moulton & Utex Ore Stockplled at Monticello & $7 / 54$ \\
\hline ACCO-57 & $\begin{array}{l}\text { R. Hollis, } \\
\text { Abrams, } \\
\text { McArthur, } \\
\text { Izzo, } \\
\text { Wilson }\end{array}$ & $\begin{array}{l}\text { Pllot Plant Tests on Anaconda Ore } \\
\text { from Grants District, Grants, New } \\
\text { Mexico }\end{array}$ & $7 / 54$ \\
\hline $\operatorname{ACCO}-58$ & Moulton & $\begin{array}{l}\text { Field Work Performed at Monticello, } \\
\text { Utah, Including Stockplie Amenability } \\
\text { and Ion Exchange }\end{array}$ & $7 / 54$ \\
\hline
\end{tabular}


ACCO REPORTS

(Continued)

\begin{tabular}{|c|c|c|c|}
\hline Number & Authors & Iitle & $\begin{array}{l}\text { Date of } \\
\text { Issue }\end{array}$ \\
\hline ACCO-59 & Kazanjian & $\begin{array}{l}\text { Systematic Elution Studies, } \\
\text { Part I, The Effect of Sul- } \\
\text { fate Accumulation on the Elution } \\
\text { of Uranium from Strong Base Ion } \\
\text { Exchange Resins with Chloride }\end{array}$ & $7 / 54$ \\
\hline$A C C O-60$ & $\begin{array}{l}\text { Toohey, } \\
\text { Kaufman }\end{array}$ & $\begin{array}{l}\text { The Relationship Between Oxidation } \\
\text { and Reduction Potential and Valence } \\
\text { State of Iron, Vanadium and Uranium } \\
\text { in Sulfuric Acid Leach Iiquors }\end{array}$ & $7 / 54$ \\
\hline ACCO-61 & O'Connor & $\begin{array}{l}\text { Ion Exchange Studies, Part I, } \\
\text { Equilibrium Constants, Part II, } \\
\text { Nature of Uranium Adsorption }\end{array}$ & $7 / 54$ \\
\hline $\operatorname{ACCO}-62$ & $\begin{array}{l}\text { O'Rourke, } \\
\text { Ladner }\end{array}$ & $\begin{array}{l}\text { Investigation of the Poisoning } \\
\text { of West Rand Anton Exchange Resins }\end{array}$ & $7 / 54$ \\
\hline ACCO-63 & $\begin{array}{l}\text { McLean, } \\
\text { E. Hollis, } \\
\text { Eisenhauer, } \\
\text { Shepherdson, } \\
\text { Cole }\end{array}$ & $\begin{array}{l}\text { Development of an Ion Exchange } \\
\text { Process for the Recovery of } \\
\text { Vanadium }\end{array}$ & $7 / 54$ \\
\hline ACCO-64 & McLean & $\begin{array}{l}\text { Process Development Studies for } \\
\text { Lukachuka1 Ores }\end{array}$ & $4 / 55$ \\
\hline$A C C 0-65$ & $\begin{array}{l}\text { Charles, } \\
\text { Thorpe, } \\
\text { Lower, } \\
\text { Kaufman, } \\
\text { Schiff, } \\
\text { Abrams, } \\
\text { Porter, } \\
\text { Viklund, } \\
\text { Howland }\end{array}$ & $\begin{array}{l}\text { The Development of Fixed Screen } \\
\text { Resin-in-Pulp Devices }\end{array}$ & $8 / 54$ \\
\hline ACCO-66 & $\begin{array}{l}\text { Ladner, } \\
\text { Lower }\end{array}$ & $\begin{array}{l}\text { Laboratory Scale Abrasive Tests } \\
\text { on Ion Exchange Reșins }\end{array}$ & $7 / 54$ \\
\hline $\mathrm{ACCO}-67$ & Allen & $\begin{array}{l}\text { A Summary of Research and Develop- } \\
\text { ment Work on Low Grade Uranfum Ores }\end{array}$ & $5 / 55$ \\
\hline$A C C O-68$ & $\begin{array}{l}\text { Kaufman, } \\
\text { Lower }\end{array}$ & $\begin{array}{l}\text { A Summary Report on the Ion Exchange } \\
\text { Process for the Recovery of Uranium }\end{array}$ & $7 / 54$ \\
\hline
\end{tabular}


TOPICAL REPORTS

MTT MTNERAL FNGTNIETRING IABORATORY

(From MITG-270)

\begin{tabular}{|c|c|c|c|}
\hline Number & Authors & Title & $\begin{array}{l}\text { Date of } \\
\text { Igsue }\end{array}$ \\
\hline MITG-PRI & Blake & Flotation Test Work & $1 / 45$ \\
\hline MITG-PR2 & Blake & Flotation Test Work & $2 / 45$ \\
\hline MITG-PR3 & Blake & $\begin{array}{l}\text { Leaching Tests - } 803 \text { Ores } \\
\text { and Minersls }\end{array}$ & $4 / 45$ \\
\hline MITG-PR4 & $\begin{array}{l}\text { Blake, } \\
\text { Bowdish }\end{array}$ & $\begin{array}{l}\text { Flowing Film Concentration - } \\
\text { Deslimed Ore }\end{array}$ & $5 / 45$ \\
\hline MITG-PR5 & Blake & Flotation Test Work (R-10) & $5 / 45$ \\
\hline MITG-MI & Melum & $\begin{array}{l}\text { Report on Heavy Liquid Separa- } \\
\text { tions }\end{array}$ & $3 / 45$ \\
\hline MITG-M2 & Gaudin & Mineralogy Report on $R-10$ Ore & $3 / 45$ \\
\hline MITG-M3 & Mitchell & Fluorescent Microscopy & $4 / 45$ \\
\hline $\mathrm{MTTG}-\mathrm{ML}_{4}$ & Sohuhmann & Treatment of Ore $\mathrm{R}-10$ & $4 / 45$ \\
\hline MITG-M5 & Schuhmann & $\begin{array}{l}\text { Inspection Trip - Scrubbing } \\
\text { and Washing Equipment }\end{array}$ & $7 / 45$ \\
\hline MITG-M6 & Dundon & $\begin{array}{l}\text { Use of Centrifugal Apparatus for } \\
\text { Desliming and Acld and Alkali } \\
\text { Leaching of R-10 Ore at Room } \\
\text { Temperature }\end{array}$ & $7 / 45$ \\
\hline MITG-M7 & Gaudin & Report of Sample SS94D & $10 / 45$ \\
\hline MITG-M8 & Schuhmann & $\begin{array}{l}\text { Inspection Trip of Leaching } \\
\text { Plants }\end{array}$ & $10 / 45$ \\
\hline MITG-M9 & Gaudin & Report of Sample SS95E & $10 / 45$ \\
\hline MITG-MIO & Gaudin & $\begin{array}{l}\text { Revlew of Progress Investiga- } \\
\text { tion of African Ores. }\end{array}$ & $12 / 45$ \\
\hline MITG-MII & Gaudin & $\begin{array}{l}\text { Status of Proposed Treatment } \\
\text { Process and Treatment Plant } \\
\text { for African Ores }\end{array}$ & $1 / 46$ \\
\hline
\end{tabular}


WIN-II5

MII REPORTS

(Continued)

\begin{tabular}{|c|c|c|c|}
\hline Number & Authors & Iitle & $\begin{array}{c}\text { Date of } \\
\text { Issue }\end{array}$ \\
\hline MITG-M12 & Mitchell & Mineralogy of Sample SS91A & $1 / 46$ \\
\hline MITG-MI3 & Mitchell & Mineralogy of Ore SS92B & $3 / 46$ \\
\hline MITG-MI4 & Gaudin & Mineralogy of SS97G & $7 / 46$ \\
\hline MITG-MI5 & Mitchell & Mineralogy of Ore SS93C & $8 / 46$ \\
\hline MITG-MI6 & Mitchell & Mineralogy of Ore SS96F & $9 / 46$ \\
\hline MITG-MI7 & $\begin{array}{l}\text { Gaudin, } \\
\text { Schuhmann }\end{array}$ & $\begin{array}{l}\text { Investigation of African Ores } \\
\text { (Final Report) }\end{array}$ & $10 / 46$ \\
\hline MITG-MI8 & Gaudin, Tyler & $\begin{array}{l}\text { Concerning a National Policy } \\
\text { for the Development of Domestic } \\
\text { Resources of Flssionable Elements }\end{array}$ & $11 / 46$ \\
\hline MITG-EI & Blake, Bowdish & $\begin{array}{l}\text { Ore 89-E - Preliminary Sink- } \\
\text { Float Tests }\end{array}$ & $5 / 45$ \\
\hline MITG-E2 & $\begin{array}{l}\text { Blake, Bowdish, } \\
\text { Schuhmann }\end{array}$ & $\begin{array}{l}\text { Concentration Tests on Ore } \\
\text { Sample } 89-\mathrm{E}\end{array}$ & $7 / 45$ \\
\hline MITO-E3 & Bowdish & $\begin{array}{l}\text { Preliminary Blunging and } \\
\text { Leaching Tests on Ores, A, B, } \\
\text { C, D, and F }\end{array}$ & $9 / 45$ \\
\hline MITG-E4 & Blake, Gaudin & $\begin{array}{l}\text { Gravity Concentration Tests on } \\
A, B, C, D \text {, and } F\end{array}$ & $10 / 45$ \\
\hline MITG-E5 & $\begin{array}{l}\text { Schuhmann, } \\
\text { Bowdish, } \\
\text { Dundon, } \\
\text { Mitchell }\end{array}$ & Blunging and Sizing Tests & $1 / 46$ \\
\hline MITG-E6 & Brandenberger & $\begin{array}{l}\text { Leaching Experiments on African } \\
\text { Ores }\end{array}$ & $3 / 46$ \\
\hline MITG-E7 & $\begin{array}{l}\text { Dundon, } \\
\text { Schuhmann }\end{array}$ & $\begin{array}{l}\text { Precipitation of Leach Liquors } \\
\text { and Dewatering of the Precipitate }\end{array}$ & $6 / 46$ \\
\hline MITG-E8 & $\begin{array}{l}\text { Schuhmann, } \\
\text { Brandenberger, } \\
\text { Bowdish }\end{array}$ & $\begin{array}{l}\text { Agitation Leaching with Sulfurlc } \\
\text { Acld-Ferric Sulfate Solution }\end{array}$ & $5 / 46$ \\
\hline
\end{tabular}


WIN-115

MIT REPORTS

(Continued)

\begin{tabular}{|c|c|c|c|}
\hline Number & Authors & Itite & $\begin{array}{l}\text { Date of } \\
\text { Issue }\end{array}$ \\
\hline MITG-E9 & Gaudin & $\begin{array}{l}\text { Mineralogical Characteristics } \\
\text { and Leaching Behavior of Meta- } \\
\text { torbernite of Certain of } 1 \text { ts } \\
\text { Dehydration Products }\end{array}$ & $6 / 46$ \\
\hline MITG-E10 & Bowd1sh & $\begin{array}{l}\text { Settling of Ores and Leach } \\
\text { Residues }\end{array}$ & $6 / 46$ \\
\hline MITG-EII & Dundon & $\begin{array}{l}\text { Precipitation of Leach Liquors } \\
\text { and Dewatering of the Precipitate }\end{array}$ & $7 / 46$ \\
\hline MITG-E12 & Bowdish & $\begin{array}{l}\text { A preliminary Study of the } \\
\text { Extraction of Cobalt from } 308 \\
\text { Leach Residue }\end{array}$ & $7 / 46$ \\
\hline MITG-E13 & Kneppel & $\begin{array}{l}\text { Extraction of Cobalt from } \\
\text { African Ores }\end{array}$ & $9 / 46$ \\
\hline MITG-E14 & $\begin{array}{l}\text { Schiff, } \\
\text { Greenewald }\end{array}$ & $\begin{array}{l}\text { Treatment of the Double-Letter } \\
\text { Samples of African Ores by } \\
\text { Direct Leaching and by Leaching } \\
\text { after Removal of Carbonates by } \\
\text { Flotation }\end{array}$ & $10 / 46$ \\
\hline MITG-SI & Tylex & Proposed Thorium Program & $8 / 47$ \\
\hline MITG-S2 & Tyler & Proposed Beryllium Ore Program & $8 / 47$ \\
\hline MITG-S3 & Tyler & $\begin{array}{l}\text { Notes on Source Materials for } \\
\text { Atomic Energy }\end{array}$ & $8 / 47$ \\
\hline MITG-S4 & - & $\begin{array}{l}\text { Minutes of Conference - July 21, } \\
1948\end{array}$ & $7 / 48$ \\
\hline MITG-S5 & Michal & The Oxidation States of Uranium & $6 / 47$ \\
\hline MITG-S6 & Macdonald & $\begin{array}{l}\text { Estimated Cost of Producing } \\
\text { Uranium from Rand Ores }\end{array}$ & $4 / 49$ \\
\hline MITG-S7 & - & $\begin{array}{l}\text { Minutes of Conference August } 2 \\
\text { and August } 3,1949\end{array}$ & $8 / 49$ \\
\hline MITG-S8 & Macdonald & $\begin{array}{l}\text { Estimated Cost of Producing } \\
\text { Uranium from Rand Ores }\end{array}$ & $9 / 49$ \\
\hline
\end{tabular}


WIN-115

MIT REPORTS

(Continued)

\begin{tabular}{|c|c|c|c|}
\hline Number & Authors & Title & $\begin{array}{c}\text { Date of } \\
\text { Issue }\end{array}$ \\
\hline MITG-S9 & $\begin{array}{l}\text { Gaudin, } \\
\text { Dasher, } \\
\text { Panneli, } \\
\text { Freyberger }\end{array}$ & $\begin{array}{l}\text { Use of an Induced Nuclear Reac- } \\
\text { tion for the Concentration of } \\
\text { Beryl }\end{array}$ & $9 / 49$ \\
\hline MITG-SIO & $\begin{array}{l}\text { Gaudin, } \\
\text { Galvanek, } \\
\text { Dasher, } \\
\text { Kaufman }\end{array}$ & $\begin{array}{l}\text { Leaching of Nitrated Materials } \\
\text { with Organic Solvents }\end{array}$ & $9 / 49$ \\
\hline MITG-S11 & $\begin{array}{l}\text { Gaudin, } \\
\text { Dasher, } \\
\text { Clevenger }\end{array}$ & $\begin{array}{l}\text { Process for Uranium Recovery } \\
\text { from Phosphoric Acid by Re- } \\
\text { duction followed by Ammonia } \\
\text { Precipitation }\end{array}$ & $9 / 49$ \\
\hline MITG-S12 & Macdonald & $\begin{array}{l}\text { Trip to the Union of South } \\
\text { Africa } 11 / 3-12 / 6 / 49\end{array}$ & $12 / 49$ \\
\hline MITG-SI3 & Kaufman & Memorandum on Patent Actions & $12 / 49$ \\
\hline MITG-S148 & $\begin{array}{l}\text { Complied by } \\
\text { Kaufman }\end{array}$ & Research Problems & $4 / 50$ \\
\hline MITG-AI & Gaudin & $\begin{array}{l}\text { Report on Work Done on Samples } \\
\text { Left with us by Dr. Bain }\end{array}$ & $4 / 46$ \\
\hline MITG-A2 & Gaudin & Recovery Time in Counter Analyses & $5 / 46$ \\
\hline MITG-A3 & Gaudın & $\begin{array}{l}\text { Preliminary Size, Gravity and } \\
\text { Magnetic Fractionations of Ores } \\
396-1 \text { and } 396-2\end{array}$ & $6 / 46$ \\
\hline MITG-A4 & $\begin{array}{l}\text { Rodden, } \\
\text { Chorney, } \\
\text { Pannell }\end{array}$ & $\begin{array}{l}\text { Report on Head Analyses for } 396-1 \\
\text { and } 396-2 \text { Ore by Chemical and } \\
\text { Counter Methods }\end{array}$ & $6 / 46$ \\
\hline MITG-A5 & Brown & $\begin{array}{l}\text { Flotation Testing on Ores } \\
\text { Number } 396-1 \text { and } 396-2\end{array}$ & $6 / 46$ \\
\hline MITG-A6 & Dasher & $\begin{array}{l}\text { Probable Errors in Results of } \\
\text { Metallurgical Tests of Ore } \\
\text { 396-2 Due to Segregation }\end{array}$ & $8 / 46$ \\
\hline
\end{tabular}


WIN-115

- 79 -

MIT REPORTS

(Continued)

Number

Authors

Title

Date of Issue

MITG-A7 Brown

Additional Flotation Test Data

$8 / 46$ on Initial Samples of Ores 396-

1 and $396-2$

MITG-A8 Brown

Flotation Tests on Initial Samples of Ores, Number 396-1 and

396-2 after Desliming

MITG-A9

Brown,

Dasher,

Tyler

Summary of Tests on Initial

$8 / 46$

Samples of Ores 396-I and

396-2

MITG-A10 Dasher

Preliminary Flotation Tests on the Large Sample of 396-2

$8 / 46$

MITG-All Chayes

Mineralogy and Fractionation

Tests of Main Sample of Ore 396-2

MITG-A12

Macdonald,

Further Flotation Tests on 396-2

$10 / 46$

Dasher

MITG-AI3

Brunner,

Direct Cyanidation of Ore 396-2

$10 / 46$

Kneppel,

Macdonald

MITG-A14

Dasher, Brown, Macdonald

Further Flotation Testing on $396-2$

$8 / 46$

$9 / 46$

MITG-AI5

Chayes, Tyler

Mineralogy and Fractionation

Tests on Ore 396-1

$11 / 46$

MITG-Al6 Dasher,

Macdonald

Flotation of Cyanided Pulps

$1 / 47$

from Ore 396-2

MITG-AI7

Dasher, Brown,

Progress in Flotation Testing Macdonald of Ore $396-2$

MITG-A18

Dasher, Brown,

Miscellaneous Flotation Tests

on Ore $396-2$

$11 / 46$

Macdonald

Preliminary Report on Testing

of Ore 396-1

$1 / 47$

$1 / 47$

MITG-A19

Dasher, Brown 
WIN-115

- 80 -

MIT REPORTS

(Continued)

Number

Authors

Title

Date of

MITG-A20

Dasher, Schiff

Ferric Sulphate-Sulphuric Acid

Issue

\begin{tabular}{|c|c|c|c|}
\hline MITG-A20 & Dasher, Schiff & $\begin{array}{l}\text { Ferric Sulphate-Sulphuric Acid } \\
\text { Leaching Process Tests on Ore } \\
396-2\end{array}$ & $1 / 47$ \\
\hline MITG-A2I & $\begin{array}{l}\text { Dasher, } \\
\text { Brunner }\end{array}$ & Recovery of Gold from Ore $396-2$ & $4 / 47$ \\
\hline MITG-A22 & $\begin{array}{l}\text { Dasher, Brown, } \\
\text { Macdonald }\end{array}$ & $\begin{array}{l}\text { Further Flotation Testing of Ore } \\
396-2\end{array}$ & $4 / 47$ \\
\hline MITG-A23 & Chayes & $\begin{array}{l}\text { Mineralogy and Fractionation } \\
\text { Tests of Ore } 396-5\end{array}$ & $4 / 47$ \\
\hline MITG-A24 & $\begin{array}{l}\text { Dasher, Brown, } \\
\text { Brunner, } \\
\text { Macdonaid }\end{array}$ & $\begin{array}{l}\text { Preliminary Tegting on Ore } \\
396-5\end{array}$ & $3 / 47$ \\
\hline MTTG-A25 & $\begin{array}{l}\text { Dasher, } \\
\text { KneppeI }\end{array}$ & $\begin{array}{l}\text { Modified Leaching for } 396 \text { Ores } \\
\text { with Cyclic Recovery of Iron }\end{array}$ & $6 / 47$ \\
\hline MITG-A26 & $\begin{array}{l}\text { Schiff, } \\
\text { Dasher }\end{array}$ & $\begin{array}{l}\text { Miscellaneous Leaching Tests } \\
\text { on 396-2 Ore }\end{array}$ & $7 / 47$ \\
\hline MITG-A27 & $\begin{array}{l}\text { Dasher, } \\
\text { Macdonald, } \\
\text { Brown, } \\
\text { Brunner, } \\
\text { Schiff }\end{array}$ & Further Testing on Ore $396-5$ & $9 / 47$ \\
\hline MITG-A28 & Pannell & $\begin{array}{l}\text { Radioassay Techniques for Low- } \\
\text { Grade U Ores and Mineral } \\
\text { Dressing Products }\end{array}$ & $5 / 47$ \\
\hline MITG-A29 & $\begin{array}{l}\text { Pannell, } \\
\text { Rubino, } \\
\text { Warren }\end{array}$ & Radiometric Research & $8 / 47$ \\
\hline MITG-A30 & Murray & $\begin{array}{l}\text { Flotation of Uraninite from } \\
\text { Other Minerals }\end{array}$ & $5 / 47$ \\
\hline MITG-A3I & Sollenberger & $\begin{array}{l}\text { The Design of a Combination- } \\
\text { Process Mill }\end{array}$ & $5 / 47$ \\
\hline
\end{tabular}


WIN-115

- 81 -

MIT REPORTS

(Continued)

\begin{tabular}{|c|c|c|c|}
\hline Number & Authors & Iftle & $\begin{array}{l}\text { Date of } \\
\text { Issue }\end{array}$ \\
\hline MITG-432 & Kaufman & $\begin{array}{l}\text { Investitgations of Wet Chemical } \\
\text { Methods for Analyses for Ura- } \\
\text { nium - Special References to } \\
\text { Low-Grade Ores }\end{array}$ & $10 / 47$ \\
\hline MITG-A33 & $\begin{array}{l}\text { Kaufman, } \\
\text { Pannell }\end{array}$ & $\begin{array}{l}\text { Disruption of Radioactive Equi- } \\
\text { librium as a Result of Flotation } \\
\text { Testing on 396-Ores }\end{array}$ & $12 / 47$ \\
\hline MITG-A34 & $\begin{array}{l}\text { Dasher, } \\
\text { Schiff }\end{array}$ & $\begin{array}{l}\text { Precipitation of Simple Leach } \\
\text { Solutions from 396-2 Ore and } \\
\text { Thickening the Precipltate }\end{array}$ & $10 / 47$ \\
\hline MITG-A35 & Michal & $\begin{array}{l}\text { Electrolytic Precipitation of } \\
\text { Urantum from Aqueous Solution }\end{array}$ & $11 / 47$ \\
\hline MITG-A36 & $\begin{array}{l}\text { Macdonald, } \\
\text { Dasher }\end{array}$ & $\begin{array}{l}\text { Cyclic and Countercurrent } \\
\text { Leaching of } 396-5 \text { Ore }\end{array}$ & $12 / 47$ \\
\hline MITC-A37. & Dasher. & $\begin{array}{l}\text { Miscellaneous Tests on Ores } \\
396-2 \text { and } 396-5\end{array}$ & $3 / 48$ \\
\hline MFTG-A38 & Brunner & $\begin{array}{l}\text { Differential Precipitation of } \\
\text { Uranium from Iron by Neutral- } \\
\text { Ization }\end{array}$ & $6 / 48$ \\
\hline MITG-A39 & Panne11 & $\begin{array}{l}\text { Preliminary Experiments in Gamma- } \\
\text { Counting Flotation Pulps }\end{array}$ & $1 / 49$ \\
\hline MITG-A40 & $\begin{array}{l}\text { Dasher, Brown, } \\
\text { George, Brunner, } \\
\text { Schiff }\end{array}$ & Tests on Vein Sample $396-3$ & $10 / 48$ \\
\hline MITG-A4I & $\begin{array}{l}\text { Dasher, Brown, } \\
\text { George, Brunner, } \\
\text { Schiff }\end{array}$ & Tests on Vein Sample $396-4$ & $10 / 48$ \\
\hline MITGa $\alpha_{42}$ & $\begin{array}{l}\text { Macdonald, } \\
\text { Brunner, } \\
\text { Schiff }\end{array}$ & $\begin{array}{l}\text { Single-Stage, Non-cyclic Leach- } \\
\text { Ing of } 396 \text { Ore }\end{array}$ & $4 / 48$ \\
\hline MITG-A43 & Brunner & $\begin{array}{l}\text { Preliminary Experiments on the Use } \\
\text { of } \mathrm{SO}_{2} \text { and Air for Production of } \\
\text { Leaching Reagents }\end{array}$ & $6 / 48$ \\
\hline
\end{tabular}


WIN-115

MIT REPORTS

(Continued)

\begin{tabular}{|c|c|c|c|}
\hline Number & Authors & Title & $\begin{array}{l}\text { Date of } \\
\text { Insue }\end{array}$ \\
\hline MITG-A44 & Bailey & $\begin{array}{l}\text { Precipitation of Uranium by } \\
\text { Inorganic Acids of Groups V } \\
\text { \& VI }\end{array}$ & $3 / 48$ \\
\hline MITG-A45 & $\begin{array}{l}\text { Kaufman, } \\
\text { Perkins }\end{array}$ & $\begin{array}{l}\text { The Spectrographic Determina- } \\
\text { tion of Uranium in Ores and } \\
\text { Ore Products }\end{array}$ & $8 / 48$ \\
\hline MITG-A46 & $\begin{array}{l}\text { Dasher, } \\
\text { Brunner, } \\
\text { Brown }\end{array}$ & $\begin{array}{l}\text { Complete Process Tests on Ore } \\
396-5\end{array}$ & $7 / 48$ \\
\hline MITG-A47 & $\begin{array}{l}\text { Kaufman, } \\
\text { Brunner }\end{array}$ & $\begin{array}{l}\text { Check-Assaying Studies of Cold } \\
\text { and Uranium in Products of the } \\
\text { Rand Mines }\end{array}$ & $12 / 48$ \\
\hline $\mathrm{MITG}-\mathrm{A} 48$ & $\begin{array}{l}\text { Sollenberger, } \\
\text { Dasher }\end{array}$ & $\begin{array}{l}\text { Countercurrent Leaching of } \\
396-5 \text { Ore with } \mathrm{SO}_{2} \text { and Air }\end{array}$ & $4 / 48$ \\
\hline MITG-A49 & $\begin{array}{l}\text { Murray, } \\
\text { Dasher }\end{array}$ & $\begin{array}{l}\text { Carbonate Treatment of } 803 \\
\text { Precipitates }\end{array}$ & $6 / 48$ \\
\hline MITG-A50 & $\begin{array}{l}\text { Brunner, } \\
\text { Jackson, } \\
\text { Porter }\end{array}$ & $\begin{array}{l}\text { Use of Packed Towers for the } \\
\mathrm{SO}_{2}-\mathrm{Alr} \text { Process }\end{array}$ & $9 / 48$ \\
\hline MITG-A5I & Michal & $\begin{array}{l}\text { The Leaching of Uranium from } \\
\text { Insoluble Hydroxides by a Car- } \\
\text { bonate Treatment }\end{array}$ & $9 / 48$ \\
\hline MITG-A52 & Bailey & $\begin{array}{l}\text { Precipitation of Uranium by } \\
\text { Organic Compounds }\end{array}$ & $12 / 48$ \\
\hline MITG-A53 & Michal & $\begin{array}{l}\text { The Recovery of Uranium from } \\
\text { Low-Grade Leach Liquors by } \\
\text { Selective Precipitation }\end{array}$ & $11 / 48$ \\
\hline MITG-A54 & Porter & $\begin{array}{l}\text { Cyclic Leaching Testa on 396-53 } \\
\text { Cyanided Residue }\end{array}$ & $2 / 49$ \\
\hline MITG-A55 & Brown & $\begin{array}{l}\text { Non-cyclic Leaching of Refrac- } \\
\text { tory Rand Ores }\end{array}$ & $1 / 49$ \\
\hline
\end{tabular}


WIN-I15

-83 -

MIT REPORTS

(Continued)

\begin{tabular}{|c|c|c|c|}
\hline Number & Authoj:g & Iitle & $\begin{array}{l}\text { Date of } \\
\text { Issue }\end{array}$ \\
\hline MITG-A56 & Macdonald & $\begin{array}{l}\text { An Investigation of Recovery of } \\
\text { Uranium from Rand Gold Ores } \\
\text { from April } 1946 \text { to July } 1948\end{array}$ & $9 / 48$ \\
\hline MITQ-A57 & $\begin{array}{l}\text { Freyberger", } \\
\text { Rubino }\end{array}$ & $\begin{array}{l}\text { Radioassay of Ieach Solutions } \\
\text { and Residues }\end{array}$ & $2 / 49$ \\
\hline MITG-A58 & George & $\begin{array}{l}\text { Fractionation Studies of Re- } \\
\text { fractory Samples from Bly- } \\
\text { voorultalcht }\end{array}$ & $4 / 49$ \\
\hline MITG-A59 & $\begin{array}{l}\text { Dasher, } \\
\text { Schiff }\end{array}$ & $\begin{array}{l}\text { Miscellaneous Tests on Pre- } \\
\text { cipitation of Rand Leach } \\
\text { Liquors with Alkall }\end{array}$ & $11 / 49$ \\
\hline MITG $-A 60$ & $\begin{array}{l}\text { Kennedy, } \\
\text { Kaufman }\end{array}$ & $\begin{array}{l}\text { A Microvolumetric Method for } \\
\text { the Determination of Small } \\
\text { Quantities of Uranium }\end{array}$ & $5 / 49$ \\
\hline MITG-A6I & Oberg & Continuous Leaching Test I & $2 / 49$ \\
\hline MITG-A62 & Bailey & $\begin{array}{l}\text { Phosphate Precipitation of } \\
\text { Uranium from Rand Ore Leach } \\
\text { Solutions and Retreatment of } \\
\text { the Phosphate Precipitates }\end{array}$ & $6 / 49$ \\
\hline MITG-A63 & $\begin{array}{l}\text { Pannell, } \\
\text { Rubino, } \\
\text { Freyberger, } \\
\text { Haney }\end{array}$ & $\begin{array}{l}\text { Radioactivity Measurements at } \\
\text { Continuous Countercurrent } \\
\text { Leaching Test }\end{array}$ & $3 / 49$ \\
\hline MITG-A64 & Schiff & $\begin{array}{l}\text { Experiments on Rand Leach } \\
\text { Liquors with Cation-Exchange } \\
\text { Resins }\end{array}$ & $8 / 49$ \\
\hline MITG-A65 & $\begin{array}{l}\text { Koskela, } \\
\text { Kaufman }\end{array}$ & $\begin{array}{l}\text { The Fluorimetric Determination } \\
\text { of Uranium, Part I }\end{array}$ & $5 / 49$ \\
\hline MITG-A67 & $\begin{array}{l}\text { Kaufman, } \\
\text { Galvanek }\end{array}$ & $\begin{array}{l}\text { Modifications in the Peroxide- } \\
\text { Colorimetric Method for } \\
\text { Uranium Developed at the MIT } \\
\text { Mineral Englneering Laboratory }\end{array}$ & $7 / 50$ \\
\hline
\end{tabular}


WIN-115

- 84 -

MTT REPORTS

(Continued)

\begin{tabular}{|c|c|c|c|}
\hline Number & Authors & IItle & $\begin{array}{l}\text { Date of } \\
\text { Issue }\end{array}$ \\
\hline MITG-A68 & Oberg & Continuous Leaching Test II & $5 / 49$ \\
\hline MITG-A69 & George & $\begin{array}{l}\text { Mineral Fractionation and } \\
\text { Leaching Tests on Portuguese } \\
\text { Uranium Ores }\end{array}$ & $3 / 49$ \\
\hline MITG-A70 & $\begin{array}{l}\text { Kaufman, } \\
\text { Castillo, } \\
\text { Koskela }\end{array}$ & $\begin{array}{l}\text { New Fluorimeters for the Deter- } \\
\text { mination of Uranium, MIT Models } \\
\text { I, II, III, \& IV }\end{array}$ & $7 / 50$ \\
\hline MITG-A7I & Haney & $\begin{array}{l}\text { Development of Counting-Rate } \\
\text { Meters for Continuous Radio- } \\
\text { assay }\end{array}$ & $4 / 50$ \\
\hline MITG-A72 & $\begin{array}{l}\text { Abrams, } \\
\text { Kaufman, } \\
\text { Dasher }\end{array}$ & $\begin{array}{l}\text { Extraction of Uranium from } \\
\text { Rand Precipitates with Carbon- } \\
\text { ates, Part I }\end{array}$ & $6 / 49$ \\
\hline MITG-A73 & $\begin{array}{l}\text { Barnard, } \\
\text { Brunner }\end{array}$ & $\begin{array}{l}\text { Carbonate Extraction of Uranium } \\
\text { from Dissolved Low-Grade Hydroxide } \\
\text { Precipitates }\end{array}$ & $4 / 50$ \\
\hline MITG-A74 & Brunner & $\begin{array}{l}\text { Further Studies on the Dotible } \\
\text { Precipitation Process }\end{array}$ & $8 / 49$ \\
\hline MITG-A75 & Barnard & $\begin{array}{l}\text { Neutralization of Reduced Rand } \\
\text { Leach Solutions }\end{array}$ & $12 / 49$ \\
\hline MITG-A76 & $\begin{array}{l}\text { Brunner, } \\
\text { Barnard, } \\
\text { Bailey }\end{array}$ & $\begin{array}{l}\text { Acid Leaching of Low-Grade } \\
\text { Uranium Precipitates from } \\
\text { Rand Ores }\end{array}$ & $10 / 49$ \\
\hline MITG-A77 & Bailey & $\begin{array}{l}\text { Retreatment of Low-Grade Hydrox- } \\
\text { ide Preclpitates by the Phosphate } \\
\text { Process }\end{array}$ & $3 / 50$ \\
\hline MITG-A78 & Brunner & $\begin{array}{l}\text { Acid Digestion-Peroxide Retreat- } \\
\text { ment Process }\end{array}$ & $1 / 50$ \\
\hline MITG-A79 & $\begin{array}{l}\text { Galvanek, } \\
\text { Kaufman }\end{array}$ & $\begin{array}{l}\text { Application of the Solvent Leach- } \\
\text { Ing Process for the Concentration } \\
\text { of Uranium from Rand Ores }\end{array}$ & $11 / 49$ \\
\hline
\end{tabular}


WIN-115

MIT REPORTS

(Continued)

\begin{tabular}{|c|c|c|c|}
\hline Number & Authors & IItle & $\begin{array}{l}\text { Date of } \\
\text { Issue }\end{array}$ \\
\hline MITG-A80 & Schiff & $\begin{array}{l}\text { Corrosion Tests in Sulfuric } \\
\text { Acid-Ferric Sulfate Leaching } \\
\text { of Siliceous Ores }\end{array}$ & $10 / 49$ \\
\hline MITG-A81 & $\begin{array}{l}\text { Abrams, } \\
\text { Kaufman }\end{array}$ & $\begin{array}{l}\text { Extraction of Uranium from } \\
\text { Rand Precipitates with Carbon- } \\
\text { ates, Part II }\end{array}$ & $2 / 50$ \\
\hline MITG-A82 & Pannell & $\begin{array}{l}\text { Accuracy of Radioassays Obtain- } \\
\text { ed with Improved Automatic } \\
\text { Sample Changer }\end{array}$ & $7 / 49$ \\
\hline MITG-A83 & $\begin{array}{l}\text { Dasher, } \\
\text { Macdonald, } \\
\text { Oberg }\end{array}$ & $\begin{array}{l}\text { Recovery of Uranium from Rand } \\
\text { Gold Ores }\end{array}$ & $1 / 50$ \\
\hline MITG-A84 & Kennedy & $\begin{array}{l}\text { Use of the Paper Column Separa- } \\
\text { tion In Estimation of Microgram } \\
\text { Quantities of Uranium }\end{array}$ & $6 / 50$ \\
\hline MITG-A85 & Bailey & $\begin{array}{l}\text { The Selective Precipitation of } \\
\text { Uranium from Reduced Rand Ore } \\
\text { Leach Solutions with Tetra- } \\
\text { sodium Pyrophosphate }\end{array}$ & $3 / 50$ \\
\hline MITG-A86 & $\begin{array}{l}\text { Kaufman, } \\
\text { Abrems }\end{array}$ & $\begin{array}{l}\text { Extraction of Uranium from } \\
\text { Rand Precipitates with Car- } \\
\text { bonates, Part III. Tests on } \\
\text { Precipitates from Type } Y \text { \& } \\
\text { Z Leach Liquors }\end{array}$ & $7 / 50$ \\
\hline MHTG-A87 & Oberg & Single Leaching, Part I & $10 / 49$ \\
\hline MITG-A88 & George & $\begin{array}{l}\text { Production of Concentrated } \\
\text { Leach Solution }\end{array}$ & $10 / 49$ \\
\hline MITG-A89 & $\begin{array}{l}\text { Abrams, } \\
\text { Kaufman }\end{array}$ & $\begin{array}{l}\text { Effect of Variables in Precipita- } \\
\text { tion and Non-cyclic Leachling of } \\
\text { Rand Ores on Recovery of Uranium } \\
\text { and the Grade of Uranium-Bearing } \\
\text { Precipltates }\end{array}$ & $-6 / 50$ \\
\hline
\end{tabular}


WIN-115

MIT REPORTS

(Continued)

Number

MITG-A90 Balley

MITG-A91

Abrams

MITG-A92

Brunner

MITG-A93 Schiff

MITG-A94 Haney

MITG-A95 Freyberger

MITG-A96

Ba1ley

MITG-A97 Barnard

MITǴ-A98

Dasher, Brunner, Abrams

MITG-A99
Pannell, Brunner ritle

Pseudocementation Interference with Pyrophosphate Precipitation of Single Leach Process $X$ Liquors

Single-Stage Leach III

$7 / 50$

Single-Stage Leaching of

$7 / 50$

Some Rand Ores with Reagents

Produced by the $\mathrm{SO}_{2}-\mathrm{A} 1 \mathrm{r}$

Process

Removal of $U$ from Rand Leach Liquors with Anion-Exchange Resins

Date of Issue

$7 / 50$

Preliminary Experiments on

Continuous Radioassay of Radioactive Ores and Mill Products

Electrolytic Reduction of Uranyl and Ferric Sulfate Solutions

$7 / 50$

$6 / 50$

Removal of Uranium from Rand

$7 / 50$ Leach Liquors with Anion-Exchange Resins II. Tests with Process X Leach Liquors

A Preliminary Study of the Ad$8 / 50$ sorption of Uranium (VI) and Other Metallic Ions by AnionExchange Resins

Assaying and Testing of Preclpitates from the GVL Pilot Plant

$5 / 50$

Tracer Studies of the Pyrophosphate Processes
$5 / 50$

$9 / 50$ 
WIN-115

MTT REPORTS

(Continued)

\begin{tabular}{|c|c|c|c|}
\hline Number & Authors & Titie & $\begin{array}{l}\text { ate of } \\
\text { Issue }\end{array}$ \\
\hline MITG-AI00 & $\begin{array}{l}\text { Macdonald, } \\
\text { Brunner, } \\
\text { Dasher, } \\
\text { Kaufman }\end{array}$ & $\begin{array}{l}\text { Recovery of Uranium from } \\
\text { Rand Gold Ores }\end{array}$ & $8 / 50$ \\
\hline MITG-A103 & Brunner & $\begin{array}{l}\text { Simultaneous Precipitation } \\
\text { of Uranium and Copper }\end{array}$ & $10 / 50$ \\
\hline MTTG-A.104 & Brunner & $\begin{array}{l}\text { Filtration of Leach Residue in } \\
\text { Extraction of Uranium from } \\
\text { Rand Cyanide Residues }\end{array}$ & $9 / 50$ \\
\hline MITG-A112 & $\begin{array}{l}\text { Pannell, } \\
\text { Haney }\end{array}$ & $\begin{array}{l}\text { Comparison of a High Pressure } \\
\text { Ion Chamber and GM Tubes for } \\
\text { Continuous Radioassaying in an } \\
\text { Ore Plant }\end{array}$ & $2 / 51$ \\
\hline MITG-A113 & Rubino & $\begin{array}{l}\text { Alpha Counting for Assay of } \\
\text { Effluents from a Resin Column } \\
\text { Treatment of Uranium Ore Leach } \\
\text { Solutions }\end{array}$ & $2 / 51$ \\
\hline MITG-20I & George & $\begin{array}{l}\text { Magnetic Separation and Miner- } \\
\text { alogy of Black Sand Concentrates } \\
\text { from California, Idaho, and Monta } \\
\text { Gold Placers }\end{array}$ & $1 / 49$ \\
\hline MITG-B2 & $\begin{array}{l}\text { Brunner, } \\
\text { George }\end{array}$ & $\begin{array}{l}\text { Reserves and Potential Produc- } \\
\text { tion of Thorium and Uranium } \\
\text { from California Gold Placers }\end{array}$ & $8 / 48$ \\
\hline MITG-B3 & George & $\begin{array}{l}\text { The Mineralogy and Distribution } \\
\text { of Radioactivity in Australian } \\
\text { Zircon }\end{array}$ & $5 / 48$ \\
\hline MITG-204 & George & $\begin{array}{l}\text { Mineralogy, Magnetic Fractiona- } \\
\text { tion and Leaching of Heavy- } \\
\text { Mineral Concentrates from } \\
\text { Climax Molybdenum Corporation }\end{array}$ & $10 / 48$ \\
\hline MITG-205 & $\begin{array}{l}\text { Dickson, } \\
\text { Kaufman }\end{array}$ & $\begin{array}{l}\text { Determination of Thorlum in } \\
\text { Low-Grade Ores }\end{array}$ & $3 / 50$ \\
\hline
\end{tabular}


MIT REPORTS

(Continued)

\begin{tabular}{|c|c|c|c|}
\hline Number & Authors & Title & $\begin{array}{l}\text { Date of } \\
\text { Issue }\end{array}$ \\
\hline MITG-206 & Frohling & $\begin{array}{l}\text { Concentration and Sizing } \\
\text { Tests with the Dutch State } \\
\text { Cone }\end{array}$ & $.12 / 48$ \\
\hline MITG-207 & Schiff & $\begin{array}{l}\text { Acid-Leaching of Western } \\
\text { Carnotite Ores }\end{array}$ & $9 / 48$ \\
\hline MITG-208 & $\begin{array}{l}\text { Pannell, } \\
\text { Patrick, } \\
\text { Rubino }\end{array}$ & $\begin{array}{l}\text { Self-Absorption of Beta Radia- } \\
\text { tion for the Discrimination } \\
\text { Between Thorium and Uranium }\end{array}$ & $1 / 49$ \\
\hline MITG-209 & $\begin{array}{l}\text { M.I.T. Min. } \\
\text { Eng. Lab. } \\
\text { Staff }\end{array}$ & $\begin{array}{l}\text { By-Product Uranium from Phos- } \\
\text { phate Outline of a Research } \\
\text { Program }\end{array}$ & $12 / 48$ \\
\hline MITG-210 & Gaudin & $\begin{array}{l}\text { Preliminary Economic Considera- } \\
\text { tions Regarding the Extraction } \\
\text { of Uranium from Western Phosphate } \\
\text { Rock }\end{array}$ & $11 / 48$ \\
\hline MITG-211 & $\begin{array}{l}\text { Frohling, } \\
\text { Dasher, } \\
\text { Kaufman }\end{array}$ & $\begin{array}{l}\text { Preliminary Experiments on Pre- } \\
\text { cipitation of Uranium from Wet- } \\
\text { Process Phosphoric Acid }\end{array}$ & $12 / 48$ \\
\hline MITG-212 & Brown & $\begin{array}{l}\text { Attrition Scrubbing of Western } \\
\text { Carnotite and Roscoelite Ores }\end{array}$ & $3 / 49$ \\
\hline MITG-213 & Dasher & $\begin{array}{l}\text { Final Report on Carnotite } \\
\text { Program }\end{array}$ & $3 / 49$ \\
\hline MITG-214 & $\begin{array}{l}\text { Pannell, } \\
\text { Freyberger }\end{array}$ & $\begin{array}{l}\text { Preliminary Experiments on the } \\
\text { Gamma, N Reaction for Analyz- } \\
\text { ing and Picking Beryl }\end{array}$ & $3 / 49$ \\
\hline MITG-215 & Clevenger & $\begin{array}{l}\text { Electrolysis of Uranium-Contain- } \\
\text { ing Phosphoric Acid Solutions }\end{array}$ & $4 / 50$ \\
\hline MITG-216 & Clevenger & $\begin{array}{l}\text { The Effect of Impurities on the } \\
\text { Precipitation of Uranium from } \\
\text { Phosphoric Acid Solutions with } \\
\text { Ammonia, Part I }\end{array}$ & $3 / 50$ \\
\hline
\end{tabular}


WIN-115

MIT REPORTS

(Continued)

\begin{tabular}{|c|c|c|c|}
\hline Number & Authors & Itle & $\begin{array}{l}\text { Date of } \\
\text { Issue }\end{array}$ \\
\hline MITG-217 & Clevenger & $\begin{array}{l}\text { Precipitation of Uranium from } \\
\text { Comercial Phosphoric Actd } \\
\text { Solutions }\end{array}$ & $7 / 49$ \\
\hline MITG-218 & $\begin{array}{l}\text { Woody, } \\
\text { Clevenger }\end{array}$ & $\begin{array}{l}\text { Precipitation of Uranium from } \\
\text { Anaconda } 270 \mathrm{Be} \text { Phosphoric Ac1d } \\
\text { with Potassium or Calcium } \\
\text { Hydroxides }\end{array}$ & $3 / 50$ \\
\hline MFTG-219 & Roethlisberger & $\begin{array}{l}\text { The Use of High Efficiency } \\
\text { Gamma Counting for Discrimi- } \\
\text { nation Between Thorium and } \\
\text { Uranium }\end{array}$ & $8 / 49$ \\
\hline MITG-220 & Rubino & $\begin{array}{l}\text { Radioassay of Products from } \\
\text { Precipitated Phosphatic Materi- } \\
\text { al }\end{array}$ & $9 / 49$ \\
\hline MITG-221 & Clevenger & $\begin{array}{l}\text { Continuous Precipitation of } \\
\text { Uranium in Commercial Phos- } \\
\text { phorlc Acid Solutions }\end{array}$ & $1 / 50$ \\
\hline MITG-222 & Brown & $\begin{array}{l}\text { Wet Scrubbing of Western } \\
\text { Phosphate Ores }\end{array}$ & $10 / 49$ \\
\hline MITG-223 & Woody & $\begin{array}{l}\text { Enriching } \mathrm{NH}_{3} \text { Precipitate } \\
\text { from Reduced Phosphoric Acld }\end{array}$ & $7 / 50$ \\
\hline MITG-224 & Pannell & The Beryl Plcker & $9 / 49$ \\
\hline MITG-225 & $\begin{array}{l}\text { Galvanek, } \\
\text { Kaufman }\end{array}$ & $\begin{array}{l}\text { Further Studies on Solvent } \\
\text { Leaching-U Recovery from } \\
\text { Eldorado Concentrate, Congo. } \\
\text { Precipitate, Rand Precipitate, } \\
\text { and Carnotites }\end{array}$ & $3 / 50$ \\
\hline MITG-226 & Schiff & $\begin{array}{l}\text { Experiments on Anaconda Phos- } \\
\text { phortc Acid with Ion-Exchange } \\
\text { Resins }\end{array}$ & $7 / 50$ \\
\hline MITG-227 & Pannell & $\begin{array}{l}\text { Quantitative Determination of } \\
\text { Beryllium by Use of the Photo- } \\
\text { disintegration Reaction }\end{array}$ & $9 / 50$ \\
\hline
\end{tabular}


MIT REPORTS

(Continued)

\begin{tabular}{|c|c|c|c|}
\hline Number & Authors & Title & $\begin{array}{c}\text { Date of } \\
\text { Issue }\end{array}$ \\
\hline MITG-228 & George & $\begin{array}{l}\text { Miscellaneous Precipitants } \\
\text { for Uranium in Phosphoric } \\
\text { Acid Solutions }\end{array}$ & $3 / 50$ \\
\hline MITG-229 & Clevenger & $\begin{array}{l}\text { Preliminary Experiments on } \\
\text { Leaching Low-Uranium Pre- } \\
\text { cipitates from Ammoniated } \\
\text { Phosphoric Acld }\end{array}$ & $5 / 50$ \\
\hline MITG-230 & $\begin{array}{l}\text { George, } \\
\text { Woody }\end{array}$ & $\begin{array}{l}\text { Preliminary Mineral Eng. Study } \\
\text { of Uranium-Bearing Ore from } \\
\text { the Sunshine Mine, Idaho }\end{array}$ & $3 / 50$ \\
\hline MITG-23I & George & $\begin{array}{l}\text { Recovery of Uranium from } \\
\text { Climax Brannerite Concentrate, } \\
\text { C-7 }\end{array}$ & $3 / 50$ \\
\hline MITG-232 & Galvanek & $\begin{array}{l}\text { Application of the Solvent } \\
\text { Leaching Process for the Con- } \\
\text { centration of Uranium from } \\
\text { Sunshine Ores }\end{array}$ & $3 / 50$ \\
\hline MITG-233 & Barnard & $\begin{array}{l}\text { Leaching of Superphosphates } \\
\text { with Saturated Solutions }\end{array}$ & $7 / 50$ \\
\hline MITG-234 & Brown & $\begin{array}{l}\text { Dry Scrubbing of Western Phos- } \\
\text { phate Ores }\end{array}$ & $5 / 50$ \\
\hline MITG-235 & $\begin{array}{l}\text { Dasher, } \\
\text { Clevenger, } \\
\text { Schiff }\end{array}$ & $\begin{array}{l}\text { Removal of Uranium from Phos- } \\
\text { phoric Acid with Monazite }\end{array}$ & $7 / 50$ \\
\hline MITG-236 & Freyberger & $\begin{array}{l}\text { Alpha Counting for Assay of } \\
\text { Ether Leach Solutions }\end{array}$ & $6 / 50$ \\
\hline MITG-237 & $\begin{array}{l}\text { Haney, } \\
\text { Rubino }\end{array}$ & $\begin{array}{l}\text { Further STudy of Simultaneous } \\
\text { Radiometric Assay for Thorium } \\
\text { and Uranium }\end{array}$ & $10 / 50$ \\
\hline MITG-238 & Clevenger & $\begin{array}{l}\text { Recovery of Uranium and Vana- } \\
\text { dium from Ammonia Process } \\
\text { Precipitates }\end{array}$ & $7 / 50$ \\
\hline
\end{tabular}


MTT REPORTS

(Continued)

\begin{tabular}{|c|c|c|c|}
\hline Number & Authors & Title & $\begin{array}{l}\text { late of } \\
\text { Issue }\end{array}$ \\
\hline MITG-239 & Kennedy & $\begin{array}{l}\text { Purification of Wet-Process } \\
\text { Phosphoric Acid by Ether }\end{array}$ & $7 / 50$ \\
\hline MITG-240 & $\begin{array}{l}\text { Woody, } \\
\text { George }\end{array}$ & $\begin{array}{l}\text { Mineral Engineering Studies } \\
\text { of Uranium Ore Samples from } \\
\text { Sunshine Mine, Kellogg, Idaho }\end{array}$ & $8 / 50$ \\
\hline MITG-24I & Clevenger & $\begin{array}{l}\text { Precipitation of Uranium from } \\
\text { Florida Phosphoric Acid }\end{array}$ & $6 / 50$ \\
\hline MITG-242 & -George & $\begin{array}{l}\text { Extraction of Uranium from } \\
\text { Florida Leach Zone, Sample E39 }\end{array}$ & $6 / 50$ \\
\hline MITG-243 & - & See Appendix A-3 & - \\
\hline MITG-244 & Ward & $\begin{array}{l}\text { A Search for Selective Solvents } \\
\text { of Uranium Nitrate from Other } \\
\text { Nitrates }\end{array}$ & $1 / 51$ \\
\hline MITG-245 & $\begin{array}{l}\text { Pannell, } \\
\text { Rubino }\end{array}$ & $\begin{array}{l}\text { Some Properties of Uranous } \\
\text { Phosphates }\end{array}$ & $9 / 50$ \\
\hline MITG-246 & Galvanek & $\begin{array}{l}\text { Lyometallurgy of Sulfated } \\
\text { Materials }\end{array}$ & $2 / 51$ \\
\hline MITG-247 & Bloecher & Lyometallurgy Survey & $1 / 51$ \\
\hline MITG-250 & $\begin{array}{l}\text { Clevenger, } \\
\text { Dasher }\end{array}$ & $\begin{array}{l}\text { Recovery of Uranium from } \\
\text { Phosphatic Materials }\end{array}$ & $9 / 50$ \\
\hline MITG-251 & Grandfield & $\begin{array}{l}\text { Fluorimetric Determination of } \\
\text { Uranium Part II, A Rapid Method } \\
\text { for the Purification of Uranium } \\
\text { in Solutions where impurity to } \\
\text { Uranium Ratio is High }\end{array}$ & $11 / 50$ \\
\hline MITG-252 & Bloecher & $\begin{array}{l}\text { Lyometallurgical Tests on } \\
\text { Marysvale Uranium Ores }\end{array}$ & $11 / 50$ \\
\hline MITG-254 & - & See Appendix A-3 & - \\
\hline
\end{tabular}


WIN-115

- 92 -

\section{MIT REPORTS}

(Cont inued)

\begin{tabular}{|c|c|c|c|}
\hline Number & Authors & Title & $\begin{array}{c}\text { Date of } \\
\text { Issue }\end{array}$ \\
\hline MITG-255 & $\begin{array}{l}\text { Woody, } \\
\text { Haney }\end{array}$ & $\begin{array}{l}\text { Continuous Radioassay of } \\
\text { Carnotite Ore at Monti- } \\
\text { cello }\end{array}$ & $12 / 50$ \\
\hline MITG-256 & Dasher & Ion Exchange on Solutions & - \\
\hline MITG-257 & $\begin{array}{l}\text { Gaudin, } \\
\text { Oberg, } \\
\text { Kunin }\end{array}$ & Ion Exchange, Resin in Pulp & - \\
\hline MITG-259 & $\begin{array}{l}\text { Pannell, } \\
\text { Morrison }\end{array}$ & $\begin{array}{l}\text { A Circuit for the Automatic } \\
\text { Control of Counting Rate } \\
\text { Meters }\end{array}$ & $12 / 50$ \\
\hline MITG-260 & - & See Appendix A-3 & - \\
\hline MITG-26I & Pannell & $\begin{array}{l}\text { Air Oxidation of Uranous } \\
\text { Solutions }\end{array}$ & $12 / 50$ \\
\hline MITG-263 & $\begin{array}{l}\text { George, } \\
\text { Abrams, } \\
\text { Galvanek, } \\
\text { Bloecher }\end{array}$ & $\begin{array}{l}\text { Preliminary Mineral Engineer- } \\
\text { ing Studies of Cupriferous } \\
\text { Uranium Ores Rl and R2 }\end{array}$ & $1 / 51$ \\
\hline MITG-A66 & Kaufman & $\begin{array}{l}\text { Miscellaneous Analytical } \\
\text { Methods (Paper Strip - } \\
\text { Thyocyanate, etc.) }\end{array}$ & $7 / 54$ \\
\hline MITG-101 & $\begin{array}{l}\text { Oberg, } \\
\text { Macdonald }\end{array}$ & Resin in Pulp Tests & $11 / 51$ \\
\hline MITG-AIO2 & Schiff & $\begin{array}{l}\text { Ion Exchange on } X \text { and } Y \\
\text { Solutions }\end{array}$ & $2 / 51$ \\
\hline MITG-A105 & Schiff & $\begin{array}{l}\text { Ion Exchange on X Solu- } \\
\text { tions Using Thickeners }\end{array}$ & $2 / 51$ \\
\hline MITG-AI06 & Clevenger & $\begin{array}{l}\text { Electrolytic Deposition of } \\
\text { Uranium from Synthetic Rand } \\
\text { Solutions }\end{array}$ & $2 / 51$ \\
\hline
\end{tabular}




\section{MIT REPORTS}

(Continued)

\begin{tabular}{|c|c|c|c|}
\hline Number & Authors & Title & $\begin{array}{l}\text { Date of } \\
\text { Issue }\end{array}$ \\
\hline MITG-AI07 & Schiff & $\begin{array}{l}\text { Effect of Some Variables } \\
\text { on Ion Exchange of Rand } \\
\text { Solutions }\end{array}$ & $3 / 51$ \\
\hline MITG-AI08 & Lower & $\begin{array}{l}\text { Synthetic Ion-Exchange } \\
\text { Studies }\end{array}$ & $2 / 51$ \\
\hline MITG-A109 & Grandfield & Analytical Use of Ferron & $6 / 53$ \\
\hline MITG-AIIO & $\begin{array}{l}\text { Woody, } \\
\text { Grandfield }\end{array}$ & Oxidizing Carbonate Leach & $2 / 51$ \\
\hline MITG-AIII & $\begin{array}{l}\text { Oberg, } \\
\text { Macdonald }\end{array}$ & Resin Life Tester & $7 / 54$ \\
\hline MITG-248 & Owens & $\begin{array}{l}\text { Miscellaneous Potentio- } \\
\text { metric Studies of Uranium } \\
\text { Solutions }\end{array}$ & $2 / 51$ \\
\hline MITG-253 & $\begin{array}{l}\text { Brown, George, } \\
\text { Kennedy }\end{array}$ & $\begin{array}{l}\text { Mineral Engineering Report } \\
\text { on Marysvale Ores } Q 1,2 \text {, and } \\
3\end{array}$ & $2 / 51$ \\
\hline MITG-258 & $\begin{array}{l}\text { Woody, George, } \\
\text { Abrams }\end{array}$ & $\begin{array}{l}\text { Recovery of Uranium and By- } \\
\text { Product Silver from Uranium } \\
\text { Ore Samples - Sunshine Mine, } \\
\text { Kellogg, Idaho }\end{array}$ & $2 / 51$ \\
\hline MITG-262 & $\begin{array}{l}\text { Kennedy, } \\
\text { George, } \\
\text { Brown, } \\
\text { Bailey, } \\
\text { Galvanek, } \\
\text { Bloecher }\end{array}$ & $\begin{array}{l}\text { Mineral Engineering Report } \\
\text { on Marysvale Ores } 44,5,6 \text {, } \\
\text { and } 7\end{array}$ & $2 / 5 I$ \\
\hline MITG-264 & $\begin{array}{l}\text { Bailey, } \\
\text { Clevenger, } \\
\text { Brunner, } \\
\text { Woody, } \\
\text { Galvanek, } \\
\text { Bloecher, } \\
\text { George, } \\
\text { Abrams }\end{array}$ & $\begin{array}{l}\text { Utah Cupriferous Uranium } \\
\text { Ores }\end{array}$ & $2 / 51$ \\
\hline
\end{tabular}


WIN-115

MIT REPORTS

(Continued)

\begin{tabular}{|c|c|c|c|}
\hline Number & Authors & Title & $\begin{array}{c}\text { Date of } \\
\text { Issue }\end{array}$ \\
\hline MITG-265 & Bloecher & Economics of Lyometallurgy & $2 / 51$ \\
\hline MITG-266 & $\begin{array}{l}\text { Haney, } \\
\text { Dasher }\end{array}$ & Ether Alarm & $2 / 51$ \\
\hline
\end{tabular}

